\title{
Media campaigns for the prevention of illicit drug use in young people (Review)
}

\author{
Ferri M, Allara E, Bo A, Gasparrini A, Faggiano F
}

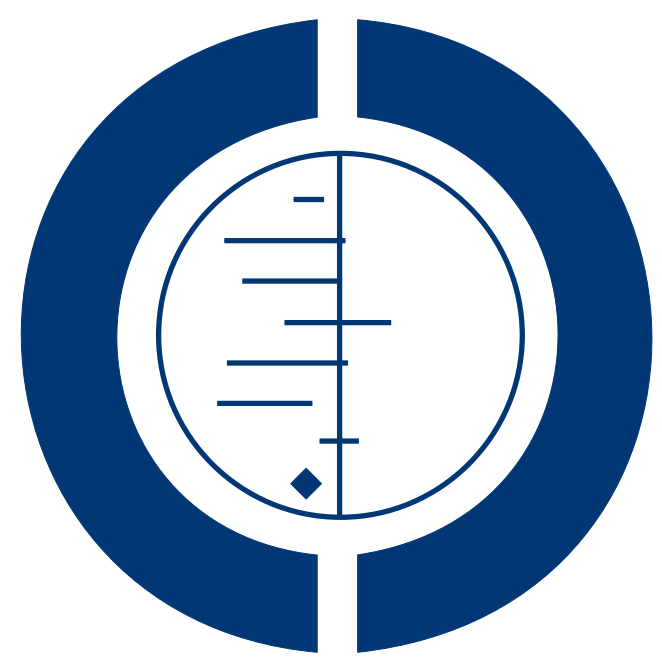

\section{THE COCHRANE COLLABORATION $^{\circledR}$}

This is a reprint of a Cochrane review, prepared and maintained by The Cochrane Collaboration and published in The Cochrane Library 2013, Issue 6

http://www.thecochranelibrary.com

\section{WILEY}

Media campaigns for the prevention of illicit drug use in young people (Review)

Copyright $\odot 2013$ The Cochrane Collaboration. Published by John Wiley \& Sons, Ltd. 
TABLE OF CONTENTS

HEADER . . . . . . . . . . . . . . . . . . . . . . . . . . . . . . . . . . . . . . . 1

ABSTRACT . . . . . . . . . . . . . . . . . . . . . . . . . . . . . . . . . . . . . . . 1

PLAIN LANGUAGE SUMMARY . . . . . . . . . . . . . . . . . . . . . . . . . . . . . . . . . . . . . . . . .

BACKGROUND . . . . . . . . . . . . . . . . . . . . . . . . . . . . . . . . . . . . . . . .

OBJECTIVES . . . . . . . . . . . . . . . . . . . . . . . . . . . . . . . . . . . . . . . . . .

METHODS . . . . . . . . . . . . . . . . . . . . . . . . . . . . . . . . . . . . . .

RESULTS . . . . . . . . . . . . . . . . . . . . . . . . . . . . . . . . . . . . . 7

Figure 1. . . . . . . . . . . . . . . . . . . . . . . . . . . . . 8

Figure 2. . . . . . . . . . . . . . . . . . . . . . . . . . . . . . . . . . . . . .

Figure 3. . . . . . . . . . . . . . . . . . . . . . . . . . . . . . . . . . . . . . 13

Figure 4. . . . . . . . . . . . . . . . . . . . . . . . . . . . . . . . . . . . . . 14

Figure 5. . . . . . . . . . . . . . . . . . . . . . . . . . . . . . . . . . . 15

Figure 6. . . . . . . . . . . . . . . . . . . . . . . . . . . . . . . . . . . . . . 16

Figure $7 . \quad$. . . . . . . . . . . . . . . . . . . . . . . . . . . . . . . . . . . . . 17

Figure 8. . . . . . . . . . . . . . . . . . . . . . . . . . . . . . . . . . . . . . 18

Figure 9. . . . . . . . . . . . . . . . . . . . . . . . . . . . . . . . . . 19

Figure 10. . . . . . . . . . . . . . . . . . . . . . . . . . . . . . . . . . . . . . . .

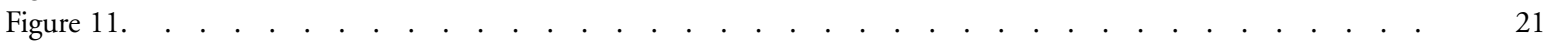

DISCUSSION . . . . . . . . . . . . . . . . . . . . . . . . . . . . . . . . . . . . . . .

AUTHORS' CONCLUSIONS . . . . . . . . . . . . . . . . . . . . . . . . . . . . . . . . . . . . . .

ACKNOWLEDGEMENTS . . . . . . . . . . . . . . . . . . . . . . . . . . . . . . . . . . . . . . . .

REFERENCES . . . . . . . . . . . . . . . . . . . . . . . . . . . . . . . . . . . . . . 25

CHARACTERISTICS OF STUDIES . . . . . . . . . . . . . . . . . . . . . . . . . . . . . . . . . . . . . . 31

DATA AND ANALYSES . . . . . . . . . . . . . . . . . . . . . . . . . . . . . . . . . . . . . . . . . . . . . . . . . . .

Analysis 1.1. Comparison 1 Mass media versus no mass media intervention (RCT), Outcome 1 Drug use. . . . . $\quad 65$

Analysis 1.2. Comparison 1 Mass media versus no mass media intervention (RCT), Outcome 2 Intention to use drugs. 66 ADDITIONAL TABLES . . . . . . . . . . . . . . . . . . . . . . . . . . . . . . . . . . . . . . . 66 APPENDICES . . . . . . . . . . . . . . . . . . . . . . . . . . . . . . . . . . . . . . . . . . . . . . 997

CONTRIBUTIONS OF AUTHORS . . . . . . . . . . . . . . . . . . . . . . . . . . . . . . . . . . . . . . 106

DECLARATIONS OF INTEREST . . . . . . . . . . . . . . . . . . . . . . . . . . . . . . . . . . . 106

SOURCES OF SUPPORT . . . . . . . . . . . . . . . . . . . . . . . . . . . . . . . . . . . . . . . . . . . . . . 


\title{
[Intervention Review]
}

\section{Media campaigns for the prevention of illicit drug use in young people}

\author{
Marica Ferri ${ }^{1}$, Elias Allara ${ }^{2}$, Alessandra $\mathrm{Bo}^{1}$, Antonio Gasparrini ${ }^{3}$, Fabrizio Faggiano ${ }^{4}$ \\ ${ }^{1}$ Interventions, Best Practice and Scientific Partners, European Monitoring Centre for Drugs and Drug Addiction, Lisbon, Portugal. \\ ${ }^{2}$ School of Public Health, University of Torino, Torino, Italy. ${ }^{3}$ London School of Hygiene \& Tropical Medicine, London, UK. \\ ${ }^{4}$ Department of Translational Medicine, Avogadro University, Novara, Italy \\ Contact address: Marica Ferri, Interventions, Best Practice and Scientific Partners, European Monitoring Centre for Drugs and Drug \\ Addiction, Cais do Sodre’ 1249-289 Lisbon, Lisbon, Portugal. marica.ferri@emcdda.europa.eu.
}

Editorial group: Cochrane Drugs and Alcohol Group.

Publication status and date: New, published in Issue 6, 2013.

Review content assessed as up-to-date: 21 May 2013.

Citation: Ferri M, Allara E, Bo A, Gasparrini A, Faggiano F. Media campaigns for the prevention of illicit drug use in young people. Cochrane Database of Systematic Reviews 2013, Issue 6. Art. No.: CD009287. DOI: 10.1002/14651858.CD009287.pub2.

Copyright (C) 2013 The Cochrane Collaboration. Published by John Wiley \& Sons, Ltd.

\begin{abstract}
A B S T R A C T
Background

Substance-specific mass media campaigns which address young people are widely used to prevent illicit drug use. They aim to reduce use and raise awareness of the problem.
\end{abstract}

\section{Objectives}

To assess the effectiveness of mass media campaigns in preventing or reducing the use of or intention to use illicit drugs amongst young people.

\section{Search methods}

We searched the Cochrane Central Register of Controlled Trials (CENTRAL, The Cochrane Library 2013, Issue 1), including the Cochrane Drugs and Alcohol Group's Specialised Register; MEDLINE through PubMed (from 1966 to 29 January 2013); EMBASE (from 1974 to 30 January 2013) and ProQuest Dissertations \& Theses A\&I (from 1861 to 3 February 2013).

\section{Selection criteria}

Cluster-randomised controlled trials, prospective and retrospective cohort studies, interrupted time series and controlled before and after studies evaluating the effectiveness of mass media campaigns in influencing drug use, intention to use or the attitude of young people under the age of 26 towards illicit drugs.

\section{Data collection and analysis}

We used the standard methodological procedures of The Cochrane Collaboration.

\section{Main results}

We included 23 studies involving 188,934 young people, conducted in the USA, Canada and Australia between 1991 and 2012. Twelve studies were randomised controlled trials (RCT), two were prospective cohort studies (PCS), one study was both a RCT and a PCS, six were interrupted time series and two were controlled before and after (CBA) studies. The RCTs had an overall low risk of bias, along

Media campaigns for the prevention of illicit drug use in young people (Review)

Copyright @ 2013 The Cochrane Collaboration. Published by John Wiley \& Sons, Ltd. 
with the ITS (apart from the dimension 'formal test of trend'), and the PCS had overall good quality, apart from the description of loss to follow-up by exposure.

Self reported or biomarker-assessed illicit drug use was measured with an array of published and unpublished scales making comparisons difficult. Pooled results of five RCTs ( $\mathrm{N}=5470)$ show no effect of media campaign intervention (standardised mean difference (SMD) $-0.02 ; 95 \%$ confidence interval (CI) -0.15 to 0.12 ).

We also pooled five ITS studies $(\mathrm{N}=26,405)$ focusing specifically on methamphetamine use. Out of four pooled estimates (two endpoints measured in two age groups), there was evidence of a reduction only in past-year prevalence of methamphetamine use among 12 to 17 years old.

A further five studies (designs = one RCT with PCS, two PCS, two ITS, one CBA, $\mathrm{N}=151,508$ ), which could not be included in meta-analyses, reported a drug use outcome with varied results including a clear iatrogenic effect in one case and reduction of use in another.

\section{Authors' conclusions}

Overall the available evidence does not allow conclusions about the effect of media campaigns on illicit drug use among young people. We conclude that further studies are needed.

\section{PLAIN LANGUAGESUMMARY}

\section{Do media campaigns prevent young people from using illicit drugs?}

Media campaigns to prevent illicit drug use are a widespread intervention. We reviewed 23 studies of different designs involving 188,934 young people and conducted in the United States, Canada and Australia. The studies tested different interventions and used several questionnaires to interview the young people about the effects of having participated in the studies brought to them. As a result it was very difficult to reach conclusions and for this reason we are highlighting the need for further studies.

\section{B A C K G R O U N D}

Health promotion, mass media campaigns are initiatives typically undertaken by national authorities which use communication media to disseminate information about, for example, health or threats to it and to persuade people to adopt behavioural changes. Mass media campaigns are implemented via television and radio broadcasts, newspaper or magazine advertisements, billboards and road posters. They can also use colourful advertisements and brochures available for travellers on buses and the metro and, more recently, a broad range of available technology including the Internet, mobile phone short messages and email lists. Media campaigns can be of short or longer duration and sometimes they encompass several consequent rounds of delivery. They can be standalone interventions or be integrated into complex social marketing programmes.

Mass media campaigns for the prevention of illicit drug use are very common worldwide but only few campaigns have been formally evaluated (Wammes 2007). Furthermore, most of those evalua- tions (Rossi 2003) assessed only the process (in terms of understanding, retention and appeal of the messages) and the very few that assessed outcomes (in terms of behaviours of use) often found weak or counterproductive effects.

\section{Description of the condition}

Initiation of use of all substances typically occurs during the teens or early years of adulthood (ESPAD 2011; UNODC 2012). Since the neurological or psychological factors that may influence how and whether addiction develops are unknown, "even occasional drug use can inadvertently lead to addiction" (Leshner 1997; Leshner 1999). Indeed, research has found that drug use leading to dependence usually starts in adolescence (Camí 2003; McLelland 2000; Swendsen 2009).

Since the neurological and social mechanisms of dependence are similar for all addictive substances, a common view, therefore, is that prevention should focus on an age group (teenagers) rather 
than specific substances (Ashton 2003; Leshner 1997; Nestler 1997; Wise 1998).

\section{Description of the intervention}

The mass media (TV, Internet, radio, newspapers, billboards) have increasingly been used as a way of delivering preventive health messages. They have the potential to modify the knowledge or attitudes of a large proportion of the community (Redman 1990). They also have the potential to reach large populations of suscepti- ble individuals and groups that may be difficult to access through more traditional approaches. In addition, in terms of the per capita cost of prevention messages, they are relatively inexpensive (Brinn 2010).

This review is limited to mass media campaigns that aim to prevent the uptake of illicit drug use (both in general or that of specific substances) or to reduce or stop the use of illicit drugs. It excludes mass media campaigns that aim to promote safer or less harmful use of drugs.

The following table summarises the main characteristics of most mass media campaign.

\begin{tabular}{|c|c|c|c|}
\hline Category & Objective & Target audience & Details \\
\hline \multirow[t]{5}{*}{ Information campaign } & Warning & General or youth population & $\begin{array}{l}\text { Information about the dangers } \\
\text { and risks of a range of illicit sub- } \\
\text { stances }\end{array}$ \\
\hline & \multirow[t]{3}{*}{ Empowerment } & \multirow[t]{2}{*}{$\begin{array}{l}\text { General population, especially } \\
\text { parents }\end{array}$} & $\begin{array}{l}\text { Information about how } \\
\text { to contribute to drug prevention } \\
\text { through your own behaviour }\end{array}$ \\
\hline & & & $\begin{array}{l}\text { Information about where and } \\
\text { how to seek support, counselling } \\
\text { and treatment regarding illicit } \\
\text { drug use, especially for your chil- } \\
\text { dren }\end{array}$ \\
\hline & & Youth population & $\begin{array}{l}\text { Information about where and } \\
\text { how to seek support, counselling } \\
\text { and treatment regarding illicit } \\
\text { drug use }\end{array}$ \\
\hline & Support & General population & $\begin{array}{l}\text { Information about existing pre- } \\
\text { vention interventions or pro- } \\
\text { grammes in communities, in } \\
\text { schools or for families in order to } \\
\text { strengthen community involve- } \\
\text { ment and support for them }\end{array}$ \\
\hline
\end{tabular}

Social marketing campaign Correct erroneous normative be- General or youth population liefs
Declared purpose is to correct erroneous normative beliefs about the extent and acceptance of drug use in peer populations ("you're not weird if you don't use because $80 \%$ of your peers don't either")

Declared purpose is to deglamorise and demystify drug use and related behaviour (e.g. drug driv- 
ing) and to explain the rationale of community norms and control measures

Setting positive role models or General or youth population Declared purpose is to promote social norms non-drug-use-related prototypes of lifestyles, behaviour and personality

\section{How the intervention might work}

Most campaigns are based on a limited number of theoretical models, such as the health belief model (lack of knowledge about health harms may lead to drug use), the theory of planned behaviour (drug use is a rational decision due to attitude toward drugs, perceived social norms and perceived control over drugs) and the social norms theory (overrated perception of prevalence among peers may lead to drug use). In summary, the theories most frequently used as base for anti-drugs mass media campaigns are:

- Health belief model. This model (Glanz 2002) is based on the concept that the perceived susceptibility to and the severity of the disease and the perceived benefits of action to avoid disease are the key factors in motivating a positive health action. So, based on some elements of the model, the provision of factual information about the negative effects and dangers of drugs should deter use or prevent substance abuse by creating negative attitudes towards drug use.

\section{Intervention based on this theory: information campaign}

- Theory of reasoned action/theory of planned behavior. The theory of reasoned action/theory of planned behaviour (Ajzen 1991) proposes that an individual's behavioural intentions have three constituent parts: the individual's attitude towards the behaviour, the social norms as perceived by the individual and the perceived control over the behaviour. Individuals may weight these differently in assessing their behavioural intentions. According to this model, drug use is a consequence of a rational decision (intention), which is based on the belief about drug use, the social norms towards drug use and the belief about control over the behaviour.

Intervention based on this theory: social marketing campaigns with the objective of setting or clarifying social and legal norms as well as information campaigns

- Social norms theory. This theory (Perkins 1986) states that "our behaviour is influenced by incorrect perceptions of how other members of our social groups think and act" (Berkowitz 2004, p. 5). Campaigns based on this theory, which are also referred to as 'normative education', challenge the misconception that many adults and most adolescents use drugs. For example, students are provided with information on the prevalence - from either national or local surveys - of drug use among their peers so that they can compare their own estimates of drug use with the actual prevalence.

- Related to this is the Super-Peer Theory (Strasburger 2008). The Super-Peer Theory postulates that media portrayal of drug use (or casual sex or violence) influences the susceptible teens.

Intervention based on this theory: social marketing campaigns that aim to correct erroneous normative beliefs

- Social learning theory. The social learning theory (Bandura 1977) postulates that personality is an interaction between environment, behaviours and the psychological processes of an individual. Also referred to as observational learning, the theory of social learning places an emphasis on observing and modelling other people's behaviours, attitudes and emotional reaction.

Intervention based on this theory: social marketing campaigns setting positive role models or social norms

\section{Why it is important to do this review}

Bühler and Kröger (Bühler 2006) conclude their review of reviews with the recommendation to use media campaigns only as supporting measures and not as a single strategy alone, whereas Hawks 2002, in line with the review of reviews by the Health Development Agency (HDA) (McGrath 2006), concludes that "the use of the mass media on its own, particularly in the presence of other countervailing influences, has not been found to be an effective way of reducing different types of psychoactive substance use. It has however been found to raise information levels and to lend support to policy initiatives".

Despite concerns in reviews about poor effectiveness and possible harm of anti-drug prevention activities (Faggiano 2008), media campaigns are still very popular worldwide and in European Union member states (EMCDDA 2009). 
An assessment of both positive and negative (iatrogenic) effects is important for ethical reasons as well, because mass media campaigns - unlike other social or health interventions - are imposed on populations that have neither asked for nor explicitly consented to the intervention (Sumnall 2007). A systematic review of all the studies assessing media campaign interventions aimed at preventing illicit drug use in young people is therefore necessary in order to inform future strategies and to help design campaigns that avoid harm. Such a review will also contribute to the identification of further areas for research.

\section{O B J E C T IVES}

To assess the effectiveness of mass media campaigns in preventing or reducing the use of or intention to use illicit drugs amongst young people.

\section{METHODS}

\section{Criteria for considering studies for this review}

\section{Types of studies}

Any study that evaluates the effectiveness of mass media campaigns in influencing drug use, intention to use or the attitude of young people towards illicit drugs.

1. Randomised controlled trials in which the unit of randomisation is an individual or a cluster (the school, community or geographical region)

2. Controlled trials without randomisation allocating schools, communities or geographical regions

3. Prospective and retrospective cohort studies

4. Interrupted time series

5. Controlled before and after studies

\section{Types of participants}

Young people under the age of 26.

\section{Types of interventions}

\section{Experimental intervention}

The following definition was adopted by a similar Cochrane review (Brinn 2010): "Mass media is defined here as channels of communication such as television, radio, newspapers, billboards, posters, leaflets or booklets intended to reach large numbers of people and which are not dependent on person to person contact". To be included in the review, a study needs to assess a mass media campaign explicitly aimed at influencing people's drug use, intention to use or attitude towards illicit drugs use.

\section{Control intervention}

1) No intervention; 2) other types of communication interventions such as school-based drug abuse prevention programmes (Faggiano 2008); 3) community-based prevention programmes; 4) lower exposure to intervention; 5) time before exposure to intervention.

\section{Types of outcome measures}

\section{Primary outcomes}

1. Self reported or biomarker-assessed illicit drug use

\section{Secondary outcomes}

1. Intentions not to use/to reduce use/to stop use

2. Attitudes towards illicit drug use

3. Knowledge about the effects of illicit drugs on health

4. Understanding of intended message and objectives

5. Perceptions (including perceptions of peer norms and perceptions about illicit drug use)

6. Adverse effects induced by the campaign (reactance, i.e. a reaction to contradict the prevailing norms of rules and positive descriptive norms, i.e. increased perception that drug use in peer population is common, normal or acceptable)

\section{Search methods for identification of studies}

\section{Electronic searches}

We obtained relevant trials from the following sources:

1. Cochrane Central Register of Controlled Trials (CENTRAL, The Cochrane Library 2013, Issue 1) which includes the Cochrane Drugs and Alcohol Group's Specialised Register;

2. MEDLINE through PubMed (freely accessible at http:// www.ncbi.nlm.nih.gov/pubmed/) (from 1966 to 29 January 2013);

3. EMBASE (from 1974 to 30 January 2013);

4. ProQuest Dissertations \& Theses A\&I (from 1861 to 3 February 2013).

We compiled detailed search strategies for each database searched. These were based on the search strategy developed for PubMed but revised appropriately for each database to take account of differences in controlled vocabulary and syntax rules. 
The search strategy for:

1. CENTRAL is shown in Appendix 1;

2. PubMed is shown in Appendix 2;

3. EMBASE is shown in Appendix 3;

4. ProQuest Dissertations \& Theses A\&I was: (media campaigns OR mass media) AND illicit drug* AND preventi* We searched for ongoing clinical trials and unpublished studies on the following Internet sites:

1. http://www.controlled-trials.com;

2. http://apps.who.int/trialsearch/;

3. http://clinicaltrials.gov/;

4. https://eudract.emea.europa.eu/.

\section{Searching other resources}

We also searched other sources to identify relevant studies. We assessed conference proceedings that were likely to contain relevant material and contacted the authors. We contacted investigators or experts in the field to seek information on unpublished or incomplete trials. We also reviewed EMCDDA National Focal Points Annual National Reports for any description of relevant studies conducted in Europe.

We used the first studies identified as fulfilling the inclusion criteria to inspect the MeSH terms and to integrate the search strategies. Moreover, we used the "related articles" function of PubMed in a "capture-recapture method" to validate the inclusiveness of the search strategy.

We did not apply any language restriction.

\section{Data collection and analysis}

\section{Selection of studies}

Two review authors (EA and MF) inspected the search hits by reading the titles and the abstracts. We obtained each potentially relevant study identified in the search in full text and at least two review authors assessed studies for inclusion independently. In case of doubts as to whether a study should have been included, this was resolved by discussion between the review authors. We collated and assessed multiple publications as one study.

\section{Data extraction and management}

Two review authors (EA and $\mathrm{AB}$ ) independently extracted data and input relevant information into Review Manager (Review Manager 2012) for meta-analysis. Two review authors (MF and FF) assessed the theoretical background of the campaigns. We discussed and solved every step by consensus. We produced a narrative synthesis of the key findings along with a meta-analysis of studies which used appropriate measures.

\section{Assessment of risk of bias in included studies}

Four review authors (EA, AB, MF and FF) performed quality assessments independently. We discussed and solved any disagreement by consensus. We uploaded final assessments into Review Manager. In order to obtain more information on the criteria for reducing risk of bias, we contacted the authors of most of the studies.

To assess RCTs we followed the criteria recommended by the Cochrane Handbook for Systematic Reviews of Interventions (Higgins 2011). The recommended approach for assessing risk of bias in studies included in Cochrane Reviews is a two-part tool, addressing seven specific domains, namely sequence generation and allocation concealment (selection bias), blinding of participants and providers (performance bias) blinding of outcome assessor (detection bias), incomplete outcome data (attrition bias) selective outcome reporting (reporting bias) and other source of bias. The first part of the tool involves describing what was reported to have happened in the study. The second part of the tool involves assigning a judgement relating to the risk of bias for that entry, in terms of low, high or unclear risk. The domains of sequence generation and allocation concealment (avoidance of selection bias) were addressed in the tool by a single entry for each study. Blinding of participants might not be applicable for this type of intervention, and we therefore considered blinding of personnel and outcome assessors (avoidance of performance bias and detection bias). We considered a study to have low risk of bias if the data were obtained with an anonymous questionnaire or administered by computer. We considered incomplete outcome data (avoidance of attrition bias) for all outcomes.

For ITS studies we used the tools developed by the Effective Practice and Organization of Care (EPOC) Group (Appendix 4). For cohort studies we used the SIGN Quality Criteria described in Appendix 5.

\section{Measures of treatment effect}

We intended to analyse dichotomous outcomes (such as intention to use or actual use of illicit substances) by calculating the risk ratio (RR) or odds ratio (OR) for each trial and express the uncertainty in each result with their $95 \%$ confidence intervals. We only found continuous outcome measures which we analysed by calculating the standardised mean difference (SMD) with its corresponding $95 \%$ confidence intervals.

\section{Unit of analysis issues}

In the case of cluster-randomised trials the unit of analysis is either the school or the town. We stated at protocol level that in this case we would have taken into account the criteria for assessing bias in cluster-randomised trials as described in the Cochrane Handbook. We inflated each arm's standard deviation for two studies (Slater 2006; Newton 2010) by multiplying it by the study design effect, 
a coefficient which takes into account the average cluster size and the study intra-class correlation.

\section{Dealing with missing data}

Where needed, we contacted the authors of the studies for integration of any possible missing data.

\section{Assessment of heterogeneity}

The presence of heterogeneity between the trials was tested using the $\mathrm{I}^{2}$ statistic and the $\mathrm{Chi}^{2}$ test. A P value of the $\mathrm{I}^{2}$ statistic higher than 0.50 and a $\mathrm{P}$ value of the $\mathrm{Chi}^{2}$ test lower than 0.10 suggests that there is some evidence of heterogeneity.

\section{Assessment of reporting biases}

We intended to use funnel plots (plots of the effect estimate from each study against the standard error) to assess the potential for bias related to the size of the trials, which could indicate possible publication bias. In fact we did not reach the minimum number of (10) studies included in the meta-analysis which is suggested as sufficient for conducting a funnel plot (Higgins 2011).

\section{Data synthesis}

We intended to carry out a meta-analysis by combining RR/OR or the SMD where possible. We performed a meta-analysis of the RCTs using a random-effect model in order to take into consideration the heterogeneity among studies.

For the studies evaluating the Meth Project (Colorado Meth 2011; Georgia Meth 2011; Hawaii Meth 2011; Idaho Meth 2010; Wyoming Meth 2011) we performed a separate meta-analysis. An interrupted time series (ITS) design was applied for estimating the differences in prevalence of methamphetamine use before and after the Meth Project intervention, adjusting for any underlying temporal trend. Statistical models were based on multilevel mixed effects logistic regression, with State as a random intercept modelling baseline log odds of methamphetamine use to vary randomly across states. The relatively few data points did not allow exploring of more complex models, e.g. the temporal trend could not be assumed to vary randomly across states. The fixed part of the final model assumes (i) a different baseline by age group, but similar among states; (ii) a linear temporal trend homogeneous across states; (iii) an effect of the intervention differing by age group but constant across time and occurring immediately after the intervention. The model may be written as logit $\left(\right.$ use $\left._{i j}\right)=\beta_{0}+$ $\mathrm{u}_{0 j}+\beta_{1}$ time $_{i}+\beta_{2}$ interv $_{i}+\beta_{3}$ age $_{i}+\beta_{4}$ agexinterv $_{i}+\epsilon_{i j}$, with use as prevalence of methamphetamine use, time as a continuous variable, intervention and age as two-level categorical variables and J indicating state. The exponentiated coefficient $\beta_{2}$ is interpretable as the ratio between the odds of using methamphetamine after (numerator) and before (denominator) the intervention (Gilmour 2006). The model was fitted separately for past-month and pastyear use of methamphetamine. Data points regarding lifetime use of methamphetamine were not analysed.

\section{Subgroup analysis and investigation of heterogeneity}

We intended to perform stratified meta-analysis in order to assess the differential effect of the campaigns based on different theoretical approaches. However the impact of media campaigns may be mediated by the sub-cultural environment and, in particular, by the attitude towards substance use in a given culture. Therefore, at protocol level it was anticipated that subsets of studies were to be analysed by characteristics of target participants (regional location, users versus non-users etc.) whenever possible. Studies could also be compared by type of campaign, based on different theoretical approaches. We did not reach the number of studies sufficient to perform any type of sub-set analysis.

\section{Sensitivity analysis}

To incorporate the assessment of risk of bias in the review process we first plotted the intervention effect estimates against the assessment of risk of bias. We subsequently inspected the results stratified for risk of bias and we did not find significant associations between measure of effect and risk of bias. We therefore decided to not include the 'Risk of bias' assessment in the meta-analysis and to discuss it narratively in the results section. The items considered in the sensitivity analysis were the random sequence, blinding of personnel and outcome assessors, and selective reporting.

\section{R E S U L T S}

\section{Description of studies}

See: Characteristics of included studies, Characteristics of excluded studies and Characteristics of studies awaiting classification.

\section{Results of the search}

The study flow chart is presented in Figure 1. 
Figure I. Study flow diagram. Please note that some studies include more than one article. This explains why there are $\mathbf{2 3}$ included studies out of $\mathbf{2 8}$ included articles.

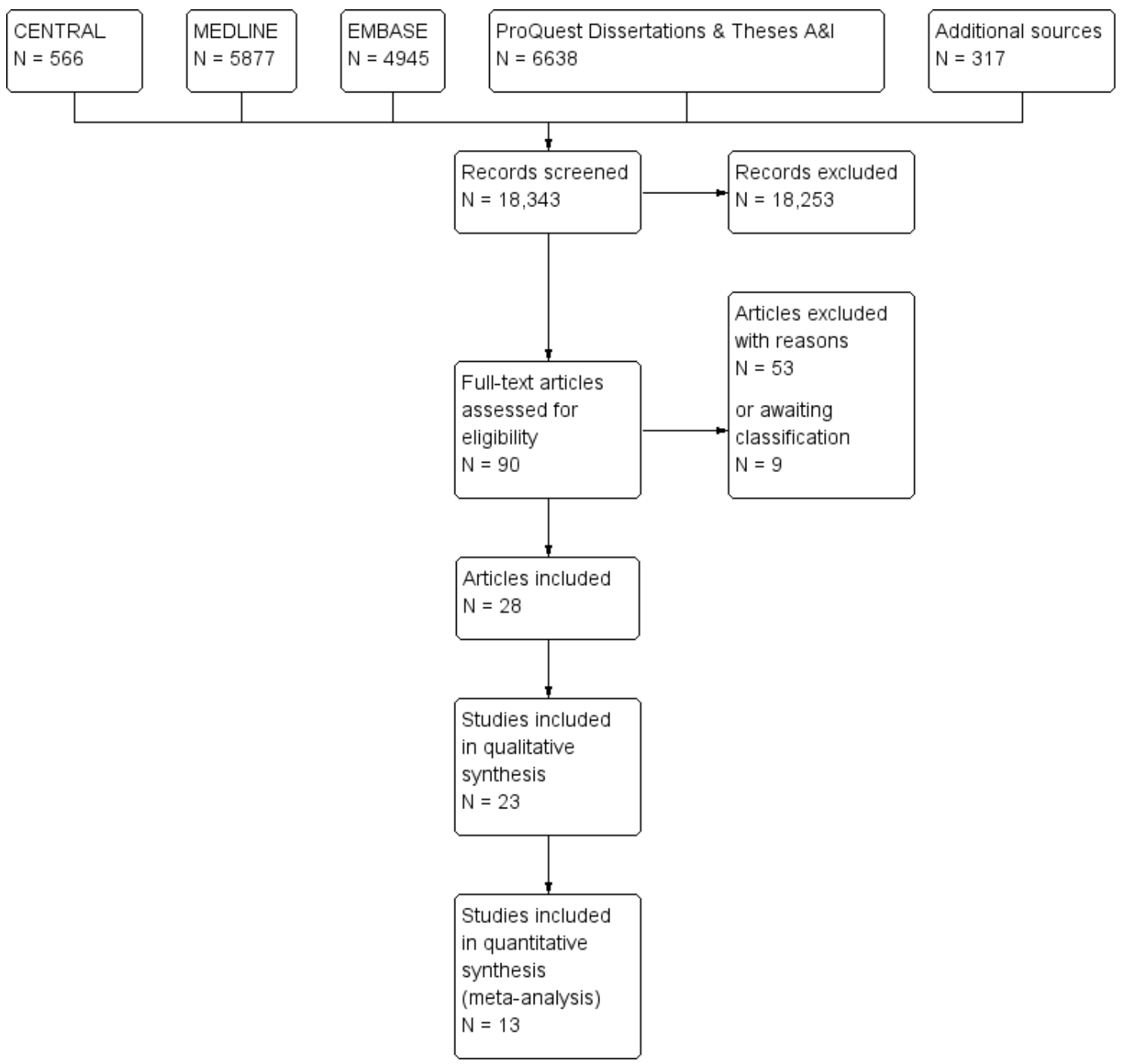

\section{Search sources}

On 29 January 2013 we performed a PubMed (MEDLINE) search as described in Appendix 2, which identified 5877 records. On 30 January 2013 we searched CENTRAL which returned 566 results and EMBASE which gave 4945 records. On 3 February 2013 we also performed a ProQuest 'Dissertations \& Theses A\&I' search which returned 6638 records.

We also obtained additional records $(\mathrm{N}=317)$ from one single paper (Hornik 2006) using PubMed's 'Similar articles' feature, and from papers extracted from 10 reviews (Battjes 1985; Berberian 1976; Hailey 2008; Kumpfer 2008; Romer 1994; Romer 1995; Schilling 1990; Stephenson 2003b; Wakefield 2010; Werb 2011), three reports (EMCDDA 2010; Know the Score 2007; NCI 2008) and three book chapters (Crano 2001; Flay 1983; Moskowitz 1983).

\section{Screening}

We independently screened records from each source search, i.e. no automatic removal of duplicates was used because of the risk of false-positive duplicates. Therefore, we screened 18,343 titles and abstracts. Of them, we excluded 18,253 records (99.5\%) as obviously irrelevant. 


\section{Full-text analysis}

We examined the full-text articles of the remaining 90 records. Of them, 62 records were either excluded $(\mathrm{N}=53)$ due to ineligibility of intervention type, participant age and reported outcome, or set in a pending status $(\mathrm{N}=9)$ due to missing information. We contacted authors whenever possible.

Twenty-eight records corresponded to 23 unique studies which were included in this review. A subset of 13 studies (eight RCTs and five ITS) could also be included in meta-analyses, mostly thanks to personal communication with some authors who provided us with unpublished data and additional reports.

\section{Included studies}

\section{Study design}

Out of 23 unique studies, 12 were randomised controlled trials (RCT) (Czyzewska 2007; Fang 2010; Fishbein 2002; Kelly 1992; Lee 2010; Newton 2010; Palmgreen 1991; Polansky 1999; Schwinn 2010; Slater 2011; Yzer 2003; Zhao 2006), two were prospective cohort studies (PCS) (Hornik 2006; Scheier 2010), one study was both a RCT and a PCS (Slater 2011), six were ITS (Carpenter 2011; Colorado Meth 2011; Hawaii Meth 2011; Idaho Meth 2010; Palmgreen 2001; Wyoming Meth 2011) and two were before and after (CBA) studies (Georgia Meth 2011; Miller 2000).

\section{Population}

No study enrolled subjects younger than 10 years old. Twentyone studies included subjects older than 10 and younger than 20 years old. Two studies included subjects older than 20 years old and younger than this review's limit of 26 years old; one of them included only people older than 20 (Miller 2000) and one people aged 18 to 22 (Palmgreen 1991).

Three studies included only girls (Fang 2010; Kelly 1992; Schwinn 2010). The others did not specify any sex-related selection criteria. Two studies focused on specific ethnic or racial groups: one on Mexican-American boys and girls (Polansky 1999) and one on Asian-American girls (Fang 2010). The remaining studies did not use ethnicity, racial or socioeconomic characteristics to define the selection criteria.

\section{Intervention}

\section{Mass media components}

Eight studies evaluated standalone TV/radio commercials ( Czyzewska 2007; Fishbein 2002; Kelly 1992; Palmgreen 1991; Palmgreen 2001; Polansky 1999; Yzer 2003; Zhao 2006) and four studies evaluated standalone Internet-based interventions (Fang 2010; Lee 2010; Newton 2010; Schwinn 2010). Eleven studies evaluated multi-component interventions, three regarding TV/ radio and printed advertising (Miller 2000; Slater 2006; Slater 2011) and eight regarding TV/radio commercials, printed advertisements and Internet advertising (Carpenter 2011; Hornik 2006; Scheier 2010 and the five Meth Projects). No study evaluated interventions using standalone printed advertising.

Three studies added a school-based drug prevention curriculum (Slater 2006; Slater 2011) or a combination of peer education, computer resources, campus policy and campus-wide events (Miller 2000) to the mass media component(s).

\section{Setting}

Eleven studies were conducted in only one setting: eight studies in a school/college setting (Czyzewska 2007; Fishbein 2002; Kelly 1992; Lee 2010; Miller 2000; Newton 2010; Polansky 1999; Yzer 2003), two in a community setting (Fang 2010; Schwinn 2010) and one in a national/statewide setting (Palmgreen 2001).

Twelve studies were conducted in multiple settings: three in school and community settings (Palmgreen 1991; Slater 2006; Zhao 2006), eight in community and national settings (Carpenter 2011; Hornik 2006; Scheier 2010 and the five Meth Projects), while one (Slater 2011) reported evaluations of two similar but distinct interventions - one implemented in a school and community setting and one aired to the whole nation.

\section{Comparison group}

Fourteen studies compared one or more mass media interventions with no intervention (Fang 2010; Fishbein 2002; Lee 2010; Miller 2000; Palmgreen 2001; Schwinn 2010; Slater 2006; Yzer 2003; Zhao 2006 and the five Meth projects). Four studies compared higher to lower exposure to a mass media intervention (Carpenter 2011; Hornik 2006; Scheier 2010; Slater 2011). Five studies compared anti-drug advertisements with another intervention (Czyzewska 2007; Kelly 1992; Newton 2010; Palmgreen 1991; Polansky 1999). Two studies (Palmgreen 1991; Yzer 2003) had different intervention arms comparing either another intervention or no intervention. For details of control interventions see the table Characteristics of included studies.

The following table summarises the interventions evaluated and the exposure of the comparison groups, as well as the theories underlying the interventions. 


\begin{tabular}{|c|c|c|c|c|c|c|c|}
\hline \multirow[t]{2}{*}{ Studies } & \multirow{2}{*}{$\begin{array}{l}\text { Ex- } \\
\text { plicit under- } \\
\text { pinning the- } \\
\text { ory }\end{array}$} & \multicolumn{3}{|l|}{ Intervention } & \multicolumn{3}{|c|}{ Comparison group } \\
\hline & & $\begin{array}{l}\text { Inter- } \\
\text { net-based in- } \\
\text { tervention }\end{array}$ & $\begin{array}{l}\text { PSA (public } \\
\text { service - TV/ } \\
\text { radio) adver- } \\
\text { tisements }\end{array}$ & $\begin{array}{l}\text { Printed ad- } \\
\text { vertisement }\end{array}$ & $\begin{array}{l}\text { No interven- } \\
\text { tion }\end{array}$ & $\begin{array}{l}\text { Lower expo- } \\
\text { sure to inter- } \\
\text { vention }\end{array}$ & $\begin{array}{l}\text { Other inter- } \\
\text { vention/dif- } \\
\text { ferent combi- } \\
\text { nation } \\
\text { of same inter- } \\
\text { vention }\end{array}$ \\
\hline $\begin{array}{l}\text { Palmgreen } \\
1991\end{array}$ & $\begin{array}{l}\text { In- } \\
\text { fluence of sen- } \\
\text { sation-seeking } \\
\text { on drug use }\end{array}$ & & $\mathrm{X}$ & & & & $\mathrm{X}$ \\
\hline Kelly 1992 & $\begin{array}{l}\text { Role of discus- } \\
\text { sion on atti- } \\
\text { tudes and } \\
\text { opinions }\end{array}$ & & $\mathrm{X}$ & & & & $\mathrm{X}$ \\
\hline Polansky 1999 & $\begin{array}{l}\text { Decision the- } \\
\text { ory }\end{array}$ & & $\mathrm{X}$ & & & & $\mathrm{X}$ \\
\hline Miller 2000 & $\begin{array}{l}\text { Self regulation } \\
\text { theory }\end{array}$ & & $\mathrm{X}$ & $\mathrm{X}$ & $\mathrm{X}$ & & \\
\hline $\begin{array}{l}\text { Palmgreen } \\
2001\end{array}$ & $\begin{array}{l}\text { In- } \\
\text { fluence of sen- } \\
\text { sation-seeking } \\
\text { on drug use }\end{array}$ & & $\mathrm{X}$ & & $\mathrm{X}$ & & \\
\hline Fishbein 2002 & $\begin{array}{l}\text { Beliefs, norms } \\
\text { or self efficacy }\end{array}$ & & $\mathrm{X}$ & & $\mathrm{X}$ & & \\
\hline Yzer 2003 & $\begin{array}{l}\text { The- } \\
\text { ories of behav- } \\
\text { ioral change: } \\
\text { persuasion ef- } \\
\text { fects }\end{array}$ & & $\mathrm{X}$ & & $\mathrm{X}$ & & $\mathrm{X}$ \\
\hline Slater 2006 & $\begin{array}{l}\text { Social-eco- } \\
\text { logical frame- } \\
\text { work (norms } \\
\text { and expec- } \\
\text { tations influ- } \\
\text { ence drug use) }\end{array}$ & & $\mathrm{X}$ & $\mathrm{X}$ & $\mathrm{X}$ & & \\
\hline Zhao 2006 & $\begin{array}{l}\text { Normative be- } \\
\text { liefs }\end{array}$ & & $\mathrm{X}$ & & $\mathrm{X}$ & & \\
\hline
\end{tabular}


(Continued)

\begin{tabular}{|c|c|c|c|c|c|c|c|}
\hline $\begin{array}{l}\text { Czyzewska } \\
2007\end{array}$ & $\begin{array}{l}\text { Reactance the- } \\
\text { ory }\end{array}$ & & $\mathrm{X}$ & & & & $\mathrm{X}$ \\
\hline Hornik 2006 & Unclear & $\mathrm{X}$ & $\mathrm{X}$ & $\mathrm{X}$ & & $\mathrm{X}$ & \\
\hline Scheier 2010 & $\begin{array}{l}\text { Social market- } \\
\text { ing }\end{array}$ & $\mathrm{X}$ & $\mathrm{X}$ & $\mathrm{X}$ & & $\mathrm{X}$ & \\
\hline Schwinn 2010 & $\begin{array}{l}\text { Social learning } \\
\text { theory }\end{array}$ & $\mathrm{X}$ & & & $\mathrm{X}$ & & \\
\hline Lee 2010 & $\begin{array}{l}\text { Readiness to } \\
\text { change }\end{array}$ & $\mathrm{X}$ & & & $\mathrm{X}$ & & \\
\hline Fang 2010 & $\begin{array}{l}\text { Family- } \\
\text { oriented }\end{array}$ & $\mathrm{X}$ & & & $\mathrm{X}$ & & \\
\hline Newton 2010 & $\begin{array}{l}\text { Social influ- } \\
\text { ence approach }\end{array}$ & $\mathrm{X}$ & & & & & $\mathrm{X}$ \\
\hline $\begin{array}{l}\text { Idaho Meth } \\
2010\end{array}$ & \multirow{5}{*}{$\begin{array}{l}\text { Perception of } \\
\text { risk and per- } \\
\text { ception } \\
\text { of social disap- } \\
\text { proval are cor- } \\
\text { related } \\
\text { with drug con- } \\
\text { sumption }\end{array}$} & \multirow[t]{5}{*}{$\mathrm{X}$} & \multirow[t]{5}{*}{$\mathrm{X}$} & \multirow[t]{5}{*}{$\mathrm{X}$} & \multirow[t]{5}{*}{$\mathrm{X}$} & & \\
\hline $\begin{array}{l}\text { Colorado } \\
\text { Meth } 2011\end{array}$ & & & & & & & \\
\hline $\begin{array}{l}\text { Georgia Meth } \\
2011\end{array}$ & & & & & & & \\
\hline $\begin{array}{l}\text { Hawaii Meth } \\
2011\end{array}$ & & & & & & & \\
\hline $\begin{array}{l}\text { Wyoming } \\
\text { Meth } 2011\end{array}$ & & & & & & & \\
\hline Slater 2011 & $\begin{array}{l}\text { Auton- } \\
\text { omy and aspi- } \\
\text { ration percep- } \\
\text { tions as me- } \\
\text { diators mari- } \\
\text { juana use }\end{array}$ & & $\mathrm{X}$ & $\mathrm{X}$ & & $\mathrm{X}$ & \\
\hline $\begin{array}{l}\text { Carpenter } \\
2011\end{array}$ & $\begin{array}{l}\text { Unclear; eval- } \\
\text { uated } \\
\text { many hetero- } \\
\text { geneous mass } \\
\text { media } \\
\text { campaigns }\end{array}$ & $\mathrm{X}$ & $\mathrm{X}$ & $\mathrm{X}$ & & $\mathrm{X}$ & \\
\hline
\end{tabular}

Media campaigns for the prevention of illicit drug use in young people (Review)

Copyright $\odot 2013$ The Cochrane Collaboration. Published by John Wiley \& Sons, Ltd. 


\section{Outcome}

The sum of studies described in this paragraph exceeds the number of included studies because many studies measured more than one outcome.

Sixteen studies measured the effect of mass media campaigns on illicit drugs use. Thirty-six studies reported the following secondary outcomes (seven were without primary outcomes):

- seven studies: intentions not to use/to reduce use/to stop use;

- 15 studies: attitudes towards illicit drug use;

- two studies: knowledge about the effects of illicit drugs on health;

- one study: understanding of intended message and objectives;

- 11 studies: perceptions (including perceptions of peer norms and perceptions about illicit drug use).

\section{Country}

Twenty-one studies were conducted in the USA, one in the USA and Canada (Schwinn 2010), and one in Australia (Newton 2010).

\section{Duration}

No follow-up was described, or was applicable, for seven studies (Carpenter 2011; Czyzewska 2007; Fishbein 2002; Palmgreen
1991; Polansky 1999; Yzer 2003; Zhao 2006). Follow-up was shorter than 12 months for four studies (Fang 2010; Kelly 1992; Lee 2010; Schwinn 2010), and longer than or equal to 12 months for the remaining 12 studies.

\section{Excluded studies}

Several thousand studies were excluded after screening their title and abstract because they did not meet the inclusion criteria. Fifty-three studies required closer scrutiny and are listed in the Characteristics of excluded studies table.

Four were excluded because the population studied did not meet the inclusion criteria; nine studies included interventions different from our inclusion criteria The remainder were excluded because the study design did not met the inclusion criteria.

\section{Risk of bias in included studies}

\section{Randomised controlled trials (RCTs)}

Approximately half of the included studies are randomised and quasi-randomised controlled trials. One of them is a mixed RCTcohort study (Slater 2011). The results of their 'Risk of bias' assessments are presented in Figure 2 and Figure 3 and described in detail in Table 1.

Figure 2. Randomised controlled trial 'Risk of bias' graph: review authors' judgements about each risk of bias item presented as percentages across all included studies.

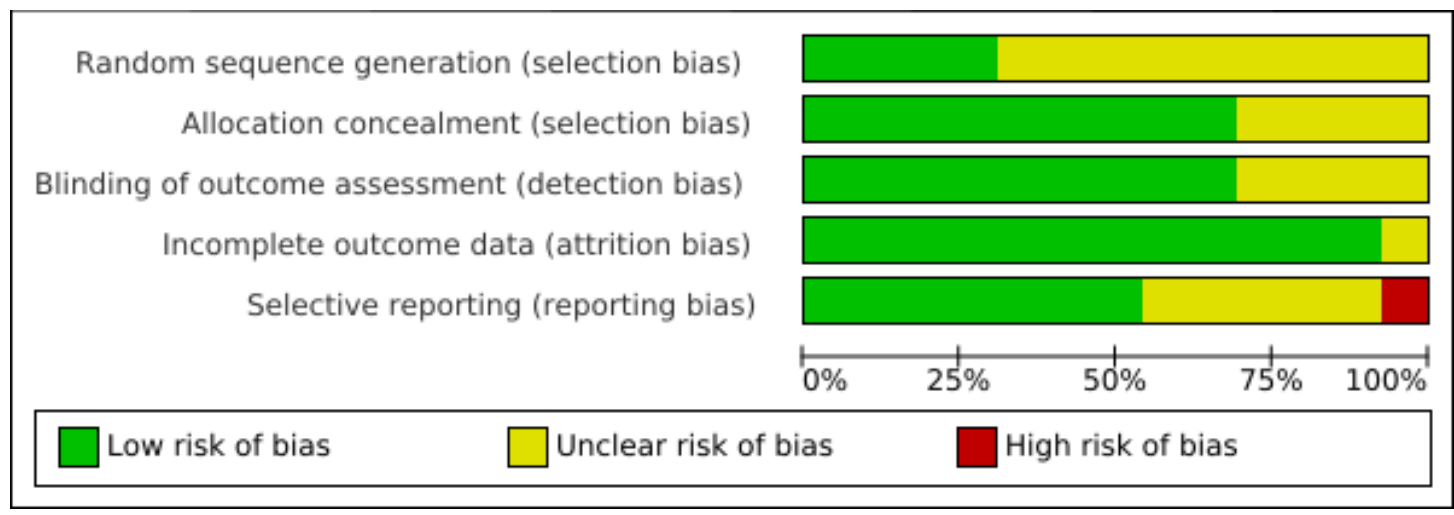


Figure 3. Randomised controlled trial 'Risk of bias' summary: review authors' judgements about each risk of bias item for each included study.

\begin{tabular}{|c|c|c|c|c|c|}
\hline & 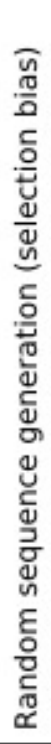 & 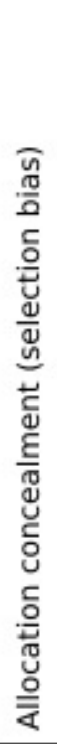 & 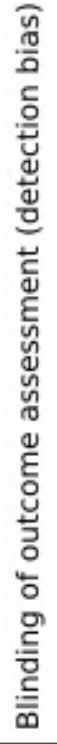 & 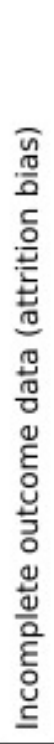 & 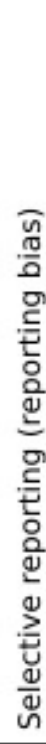 \\
\hline Czyzewska 2007 & $?$ & + & + & + & $?$ \\
\hline Fang 2010 & $?$ & + & + & + & $?$ \\
\hline Fishbein 2002 & $?$ & $?$ & + & + & + \\
\hline Kelly 1992 & $?$ & $?$ & $?$ & ) & \\
\hline Lee 2010 & + & + & + & + & $?$ \\
\hline Newton 2010 & + & + & + & 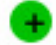 & $?$ \\
\hline Palmgreen 1991 & $?$ & $?$ & $?$ & + & \\
\hline Polansky 1999 & ? & $?$ & + & $?$ & + \\
\hline Schwinn 2010 & ? & + & + & - & \\
\hline Slater 2006 & $?$ & + & $?$ & & \\
\hline Slater 2011 & + & + & $?$ & & 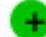 \\
\hline Yzer 2003 & + & + & + & + & 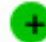 \\
\hline Zhao 2006 & ? & + & + & + & $?$ \\
\hline
\end{tabular}


Overall the quality of the included RCTs is acceptable: the stronger dimension is the consideration of risk of attrition bias (incomplete data addressed in the discussion) and the weaker dimension the risk of selection bias (unclear description of method for randomisation). More than half of the studies were clearly free of selective outcome reporting. In one case (Schwinn 2010) there was a clear indication of potential high risk of reporting bias.

\section{Other potential sources of bias}

Ecological factors are likely to interfere with the effect of a me- dia campaign. These factors can include exposures to other media campaigns (advertisements), films or mass media debates directly addressing illicit drugs or other factors acting indirectly (for example, a popular singer who dies from an overdose).

\section{Interrupted time series (ITS) and before and after studies} (CBA)

Six studies are ITS and two studies are CBA. The results of their 'Risk of bias' assessments are presented in Figure 4 and Figure 5.

Figure 4. Interrupted time series 'Risk of bias' graph: review authors' judgements about each risk of bias item presented as percentages across all included studies.

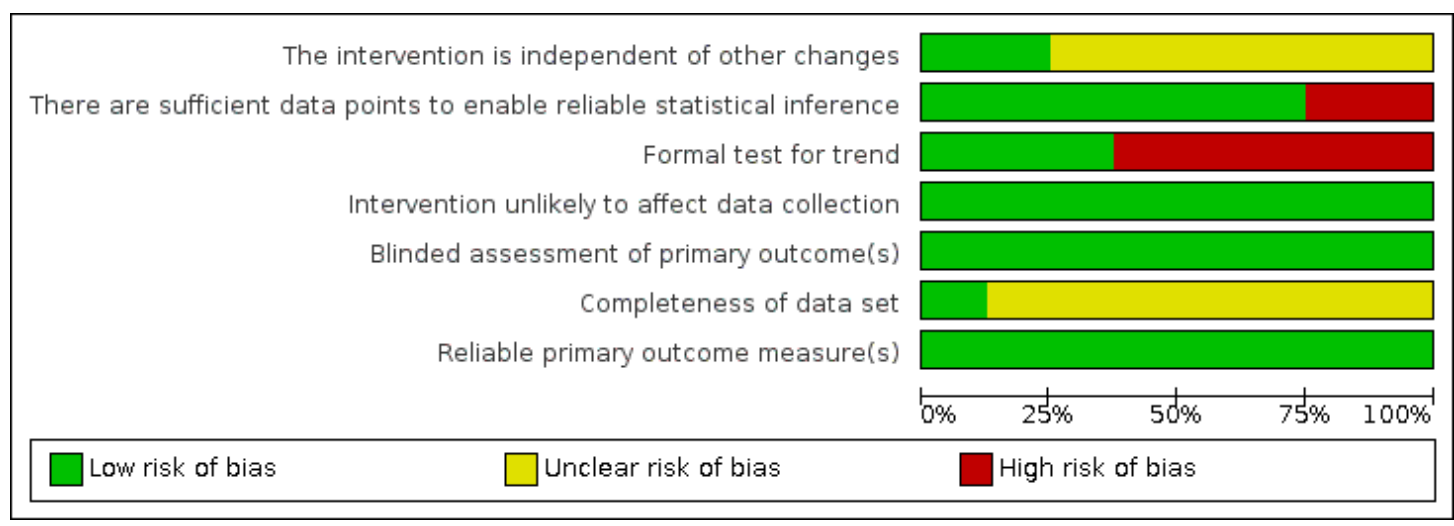


Figure 5. Interrupted time series 'Risk of bias' summary: review authors' judgements about each risk of bias item for each included study.

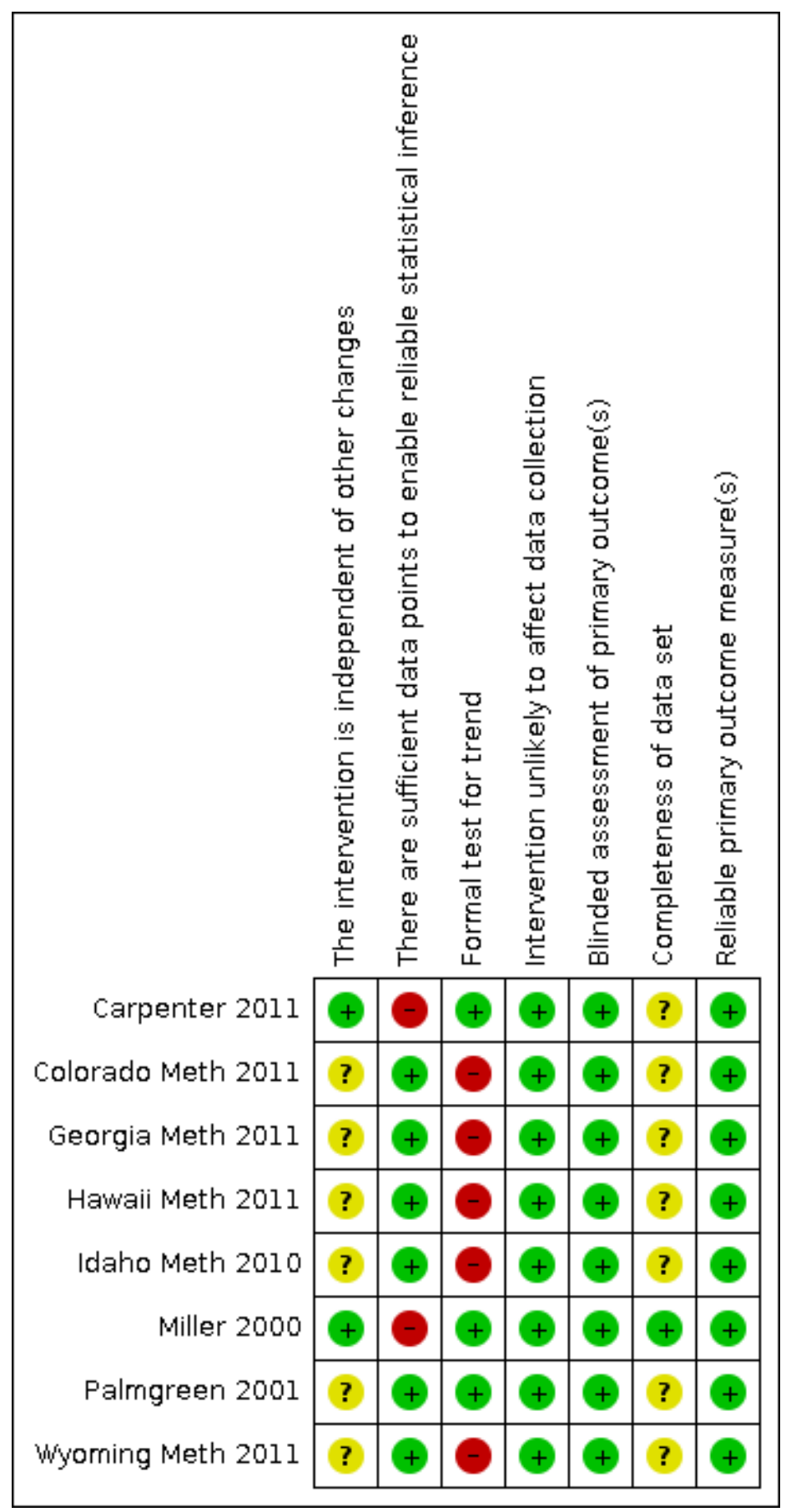

Media campaigns for the prevention of illicit drug use in young people (Review) 
Overall the studies reported sufficient data points to enable reliable statistical inferences; they also had good strategies to ensure anonymous or computer-administered questionnaires and to ensure that interventions did not affect data collection. The reliability of primary outcome measures was also satisfactory for all the studies. The weaker points were the lack of a formal test for trends and the unclear completeness of the data sets for many studies.

\section{Prospective cohort studies (PCS)}

Three studies are cohort studies and one of them is a mixed RCTcohort study (Slater 2011). The results of their 'Risk of bias' assessments are presented in Table 2, Figure 6 and Figure 7.

Figure 6. Prospective cohort studies 'Risk of bias' graph: review authors' judgements about each risk of bias item presented as percentages across all included studies

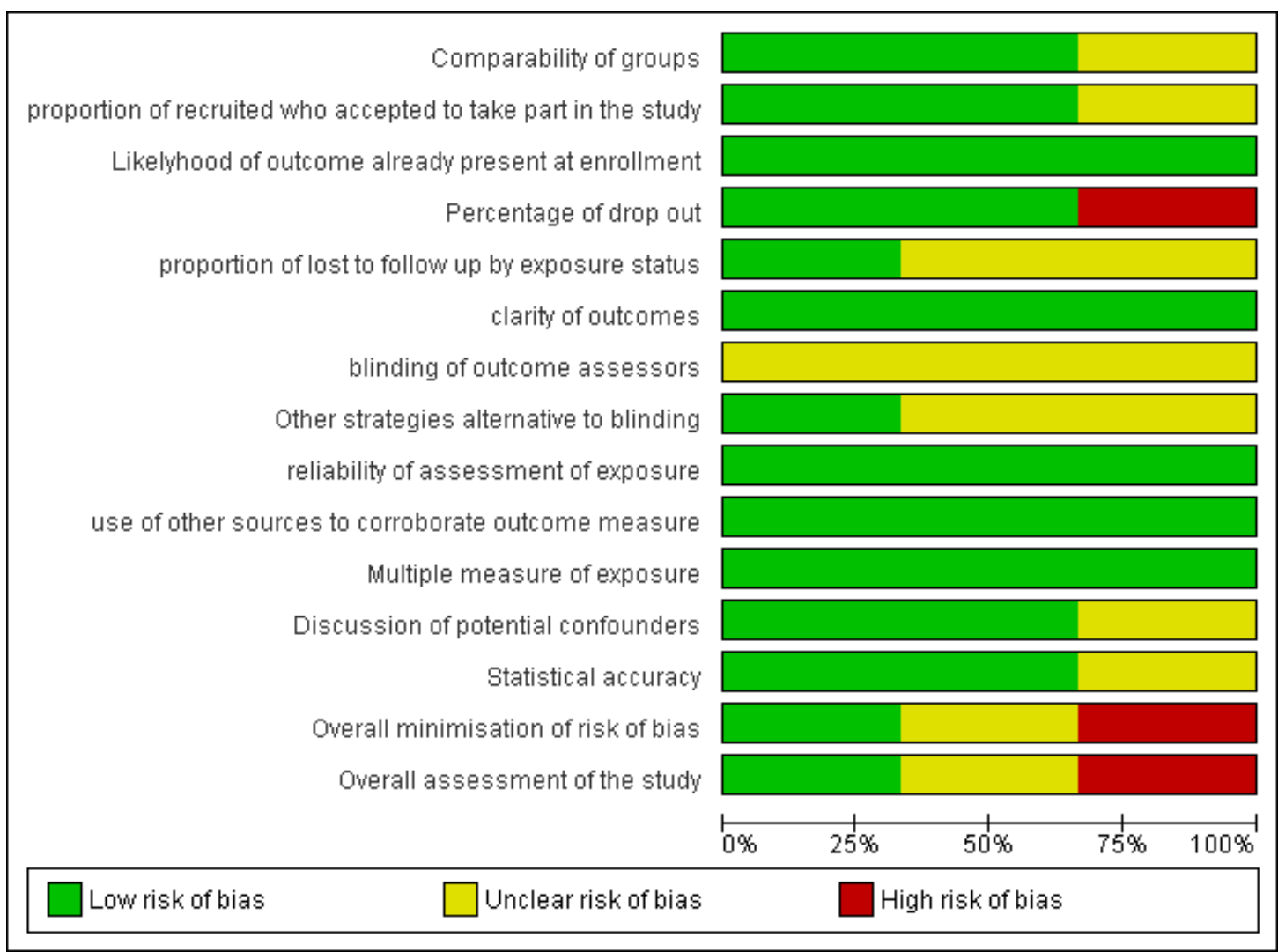

Media campaigns for the prevention of illicit drug use in young people (Review) 
Figure 7. Prospective cohort studies 'Risk of bias' summary: review authors' judgements about each risk of bias item for each included study.

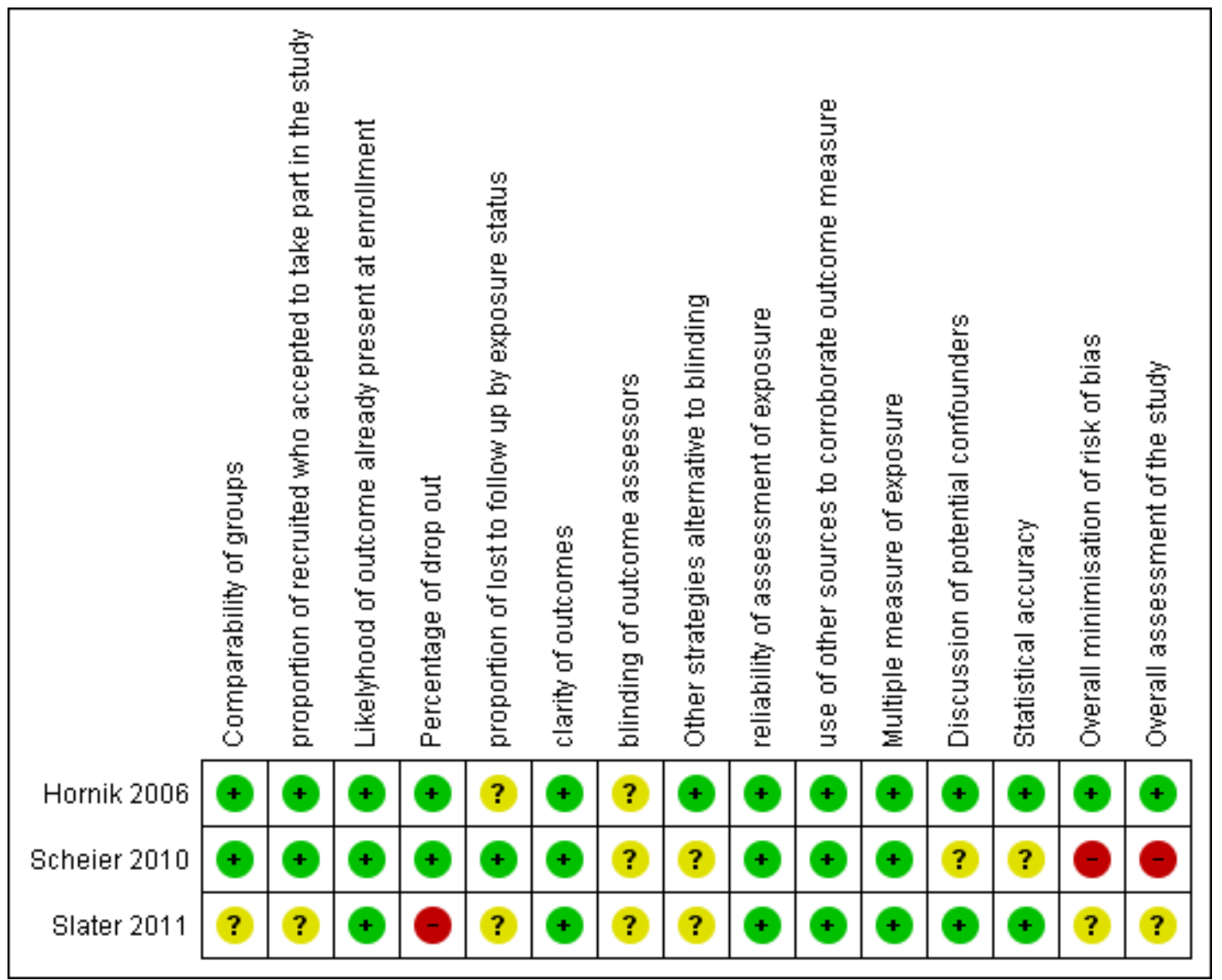

Overall, all PCS addressed an appropriate and clearly focused question. In two studies subjects were selected with proper procedures in order to make them comparable in all respects. The same two studies indicated how many of the people asked to take part actually participated in the study. One study (Slater 2011) failed to address these issues. Attrition was 35\% in two studies and $42.9 \%$ in Slater 2011. Comparison between participants and those lost to follow-up was made only in Scheier 2010.

\section{Assessment}

The outcomes were clearly defined in all studies. Blinding to exposure status was not applicable for any of the studies. In one study (Hornik 2006) there was some recognition that knowledge of exposure status could have influenced the assessment of the outcomes. In all studies the measure of assessment of exposure was reliable: evidence from other sources was used to demonstrate that the method of outcome assessment was valid and reliable, and exposure level or prognostic factor was assessed more than once.

\section{Confounding}

The main potential confounders were adequately identified and taken into account in two studies (Hornik 2006; Slater 2011).

\section{Statistical analysis}

Confidence intervals were provided in two studies. One study reported only P values (Scheier 2010).

\section{Overall assessment of the study}

One study did very well in addressing the risk of bias or confounding (Hornik 2006), one did quite well (Slater 2011) and one did not adjust for potential confounders (Scheier 2010). 


\section{Effects of interventions}

\section{Primary outcomes}

\section{Self reported or biomarker-assessed illicit drug use}

This primary outcome is measured in 15 studies: five randomised controlled trials (RCT) + one RCT and prospective cohort study; two prospective cohort studies; six interrupted time series (ITS) and one controlled before and after (CBA) study.
The five RCTs (Fang 2010; Lee 2010; Newton 2010; Schwinn 2010; Slater 2006) enrolled 5470 young people and were included in a meta-analysis (see Figure 8). Their pooled results show no effect of media campaign intervention (standardised mean difference (SMD) - 0.02; 95\% confidence interval (CI) -0.15 to 0.12 , heterogeneity $\mathrm{P}=0.02$ ) (Analysis 1.1 ). Youngsters exposed to a media campaign tend to use, on average, fewer illicit substances measured through an array of published and unpublished scales including the American Drug and Alcohol Survey (Centers for Disease Control and Prevention), Youth Risk Behavior Survey, Australian National Drug Strategy Household Survey and Global Appraisal of Individual Needs-I (see Table 3).

Figure 8. Forest plot of comparison: I Mass media versus no mass media intervention (RCT), outcome: I.I Drug use.

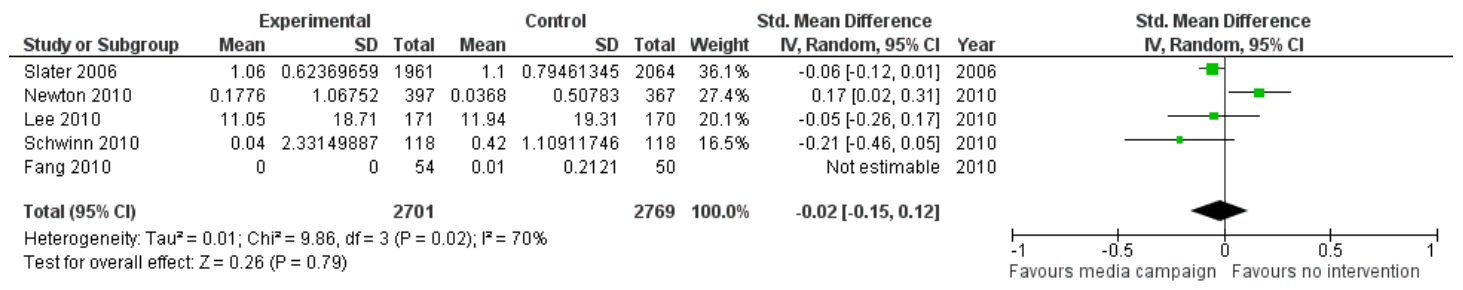

Several time points of use were available in the different studies, but we chose the six-month follow-up as a standard comparable across studies. To do this we have used both published and unpublished data kindly provided by the authors. Among the six-month assessments, Slater 2006 and Schwinn 2010 measured use in the past 30 days, Lee 2010 measured use in the past three months and Newton 2010 frequency of use in the past 12 months.

The pooled result shows no effect of the intervention, with overall significant heterogeneity among studies $(\mathrm{P}<0.05)$; this can be partially explained by the results of Newton 2010 which showed a reduction of use in the control group.

The theoretical background for the five studies was varied, with two studies based on the social learning theory (Schwinn 2010) and the social ecological framework (Slater 2006) providing the better results, whereas the study based on the social influence ap- proach (Newton 2010) favoured the control group.

Five ITS (Colorado Meth 2011; Georgia Meth 2011; Hawaii Meth 2011; Idaho Meth 2010; Wyoming Meth 2011, $\mathrm{N}=26,405$ ) evaluated the Meth Project intervention in five US states. In every study the first year reports pre-campaign figures. Observed and predicted overall and state-specific probabilities were plotted against time for both past-month (Figure 9) and past-year (Figure 10) use of methamphetamine. Among study participants aged 12 to 17 years old there was no evidence of an effect on past-month prevalence of methamphetamine (odds ratio (OR) 1.16, 95\% CI 0.63 to 2.13$)$ and evidence of a reduction in past-year prevalence (OR 0.59; 95\% CI 0.42 to 0.84). Among participants aged between 18 and 24 years old there was no evidence of an effect for past-month (OR 0.72 ; 95\% CI 0.16 to 3.20 ) or past-year (OR $0.91 ; 95 \%$ CI 0.43 to 1.94 ) prevalence of methamphetamine. 
Figure 9. Observed and predicted probabilities of past-month methamphetamine use in the Meth Project studies
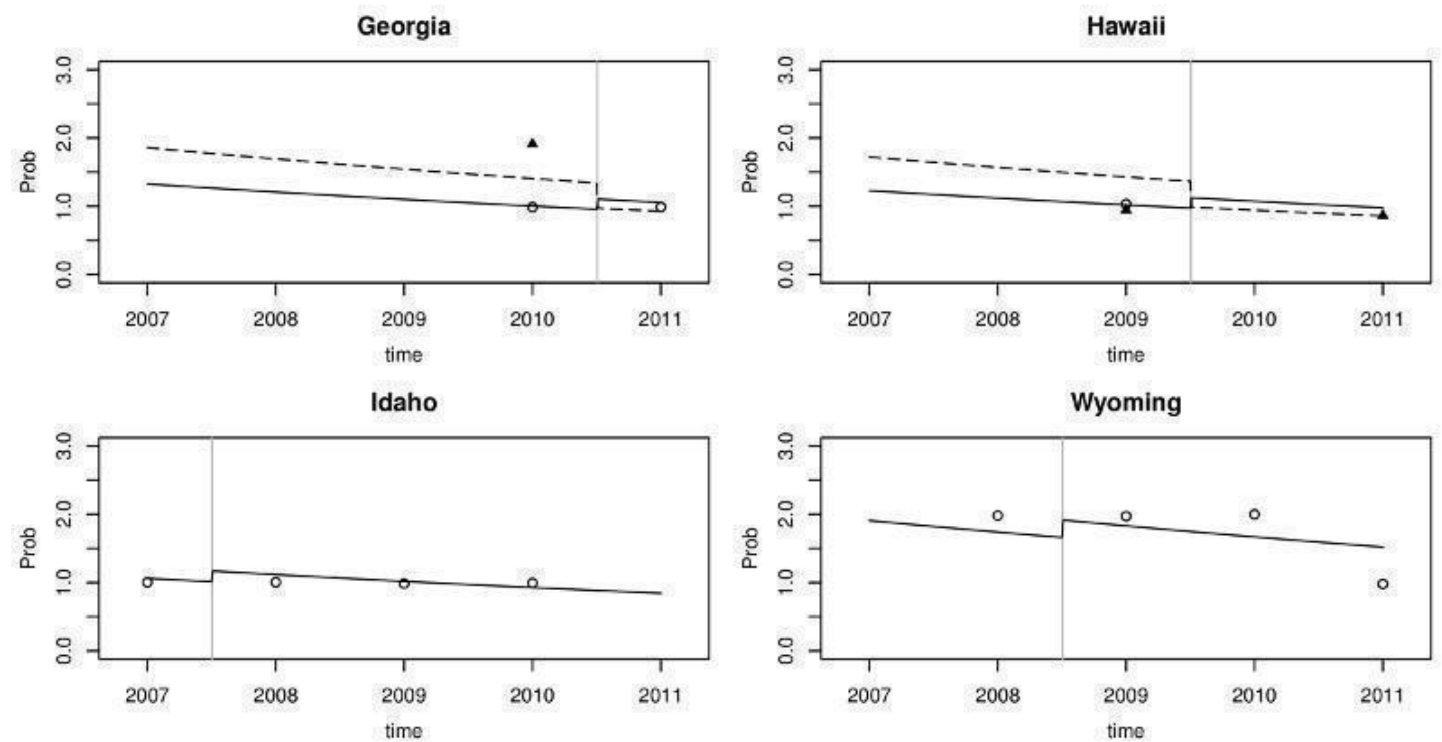

Observed probabilities
- Teens $\quad$ Y Young adults

Predicted probabilities

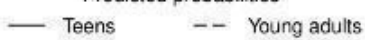


Figure 10. Observed and predicted probabilities of past-year methamphetamine use in the Meth Project studies
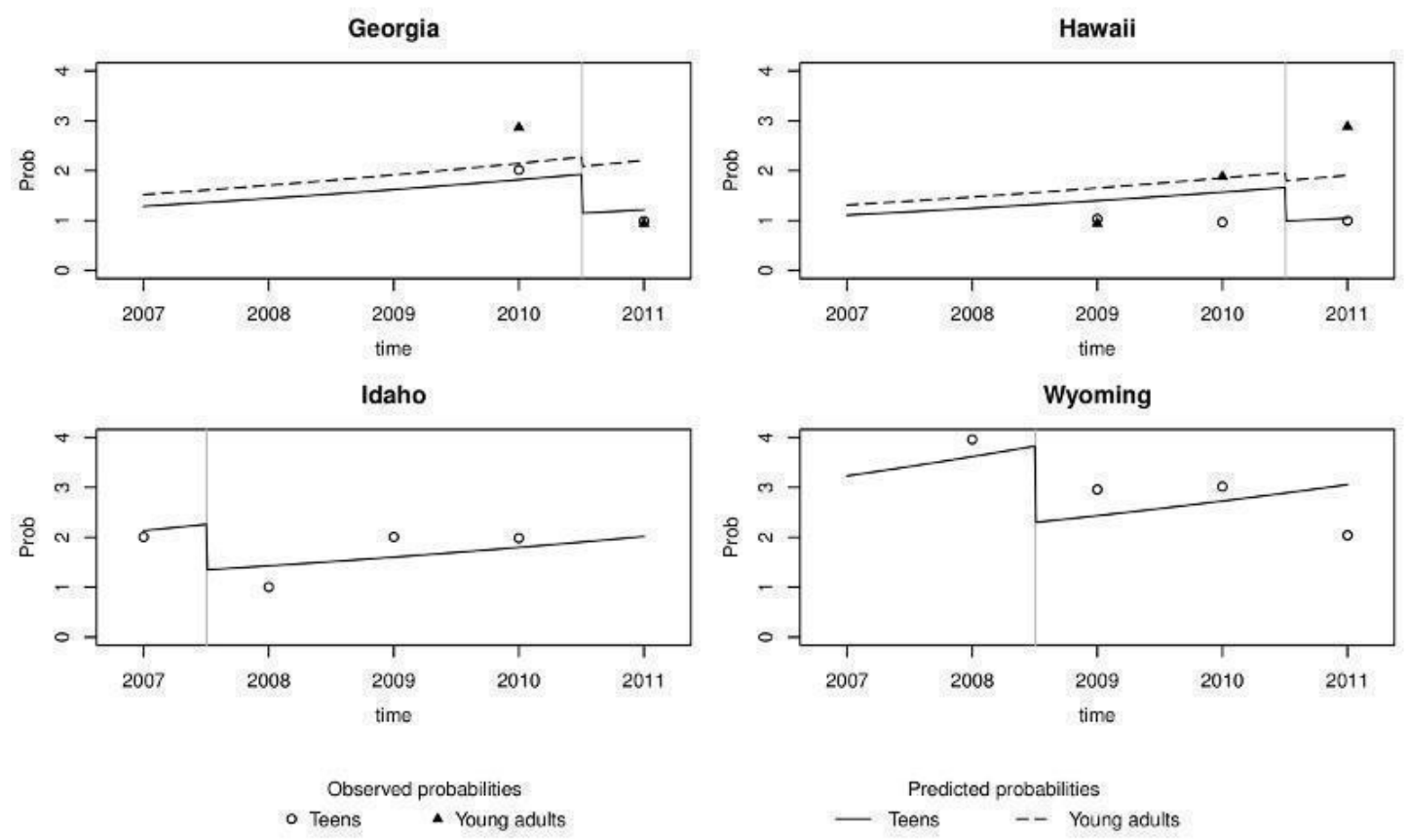

Due to the intrinsic methodological limitations of ITS studies and the impossibility of conducting more sophisticated analyses (e.g. by adjusting for potential confounders), these findings should be considered with caution.

Slater 2011, the only RCT that included a prospective cohort study(the reason why it was not included in the meta-analysis) found evidence that a community-level campaign, adjusted for the effect of a school-level campaign, reduced marijuana uptake compared to no intervention (estimate $-0.511 ; \mathrm{P}=0.026$ ).

Two prospective cohort studies $(\mathrm{N}=10,632)$ found results ranging from non-significantly effective to a significant iatrogenic effect. Namely, Scheier 2010 found that over time young participants in the experimental arms reported increasingly more awareness and recalled increasingly more campaign messages, and also a concomitant but not statistically significant decrease in their reported levels of marijuana use. Hornik 2006 measured past-year marijuana use after exposure to a national media campaign as a function of exposure to a specific advertisement at a prior round and found an increase in use (odds ratio (OR) 1.21; 95\% CI 1.19 to 1.65), controlled for considered confounders.

One ITS(Palmgreen 2001) was included in the meta-analysis because the author we contacted for this review suggested presenting the data as in the original papers. In this 32-month study, high sensation-seekers exhibited a significant upward trend in 30-day

marijuana use before exposure to the campaign and a significant downward trend after exposure. This finding was reported in both the communities involved in the study (Knox County Time Series $(P=0.001)$ and the Fayette County Time Series $(P=0.003$ and $\mathrm{P}=0.001$ after campaign 1 and 2, respectively)).

One ITS(Carpenter 2011) analysed the relationship between exposure to the 'Above the Influence' campaign in 210 US media markets and adolescent marijuana use from 2006 to 2008. The study showed lower rates of past-month (adjusted odds ratio (AOR) 0.67; 95\% CI 0.52 to 0.87) and lifetime (AOR 0.76; 95\% CI 0.62 to 0.93 ) marijuana use among girls in grade eight. For boys in grade eight and both girls and boys in grades 10 and 12 there was no evidence of an association between the campaign and a reduction in marijuana use.

The only controlled before and after (CBA) study (Miller 2000) found a modest increase in drug use in the control campus, paralleled by a modest decrease in drug use in the experimental campus, without statistical significance.

\section{Secondary outcomes}




\section{Intentions not to use/to reduce use/to stop use}

This outcome was measured by four RCTs, which found a nonstatistically significant effect in favour of media campaigns, and one prospective cohort study which, on the other hand, found a possible iatrogenic effect.

Four RCTs (Fang 2010; Polansky 1999; Yzer 2003; Zhao 2006) involving 1270 students were included in the meta-analysis (see Figure 11) and the pooled analysis shows that there is no effect (SMD -0.07; 95\% CI -0.19 to 0.04) (Analysis 1.2). Intentions to use drugs were measured with several unpublished scales and the Drug Attitude Scale (see Table 3 for a brief description of the scales used).

Figure I I. Forest plot of comparison: I Mass media versus no mass media intervention (RCT), outcome: I.2 Intention to use drugs.

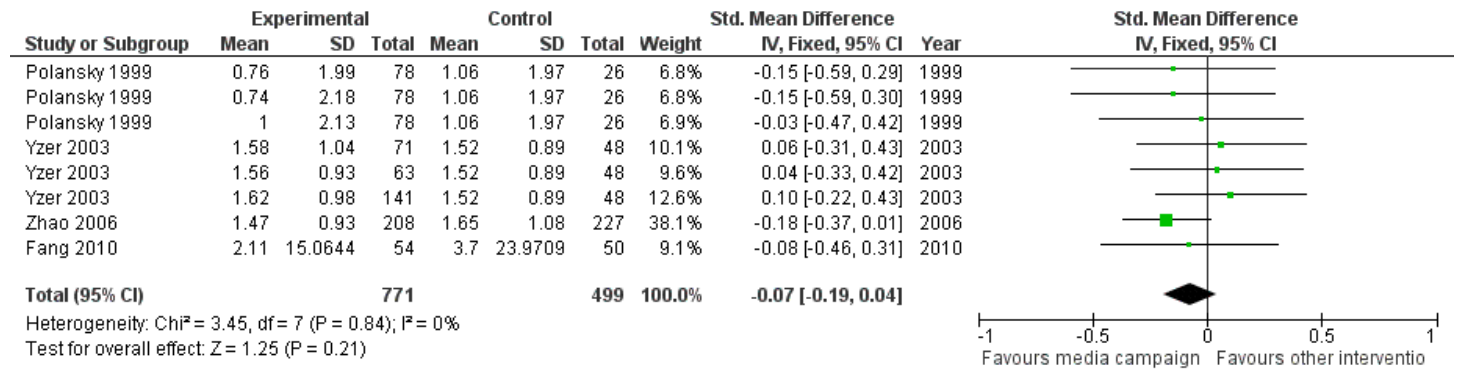

Hornik 2008 was not included in the meta-analysis because its study design (prospective cohort study) was not comparable with that adopted by the others (randomised controlled trial). The study found that at one round a higher level of exposition was associated with more intention to use marijuana (expressed as less intention to avoid marijuana use $(y=-0.07 ; 95 \%$ CI -0.13 to -0.01$)$.

\section{Attitudes towards illicit drug use}

Fourteen studies including 37,172 youngsters considered this outcome which was measured specifically by eight RCTs, one prospective cohort study and five ITS. No meta-analysis was possible and results have been described narratively. Overall, no conclusions can be drawn on the basis of the available studies.

Eight RCTs showed mixed results with four studies giving positive results and four uncertain results. For example, Palmgreen 1991 found that media campaign messages specifically targeting high sensation-seekers were more effective than controls in increasing negative attitude towards drug use. In Kelly 1992 the exposed group showed a change in attitude towards drugs. In Polansky 1999 ninth-grade students exposed to media advertisement showed more ability to resist peer pressure to use drugs than the control group. In Czyzewska 2007 the anti-marijuana advertisements group showed a tendency to more negative implicit attitudes to marijuana than the control whereas Newton 2010 showed that at the 12-month follow-up no differences between groups persisted for alcohol expectancies, cannabis attitudes or alcohol- and cannabis-related harms. The advertisements studied by Yzer 2003 targeted the belief that marijuana is a gateway to use of stronger drugs. Nevertheless results did not support this as no clear persuasion was found for any of the ad sequences. In comparison to the control condition, adolescents in the explicit gateway condition tended to agree less with the gateway message and displayed weaker correlations between anti-marijuana beliefs and their attitude towards marijuana use. Schwinn 2010 measured drug resistance/refusal skills; however they did not report results. Zhao 2006 did not find any significant effect on individual measures of attitude change.

Hornik 2006 found a small but significant increase in anti-marijuana beliefs and attitudes in students exposed to media campaigns even though this was not accompanied by significant parallel gains in intentions not to use, social norms or self efficacy.

Heterogeneous results were reported in the five included Meth 
Project studies. In Wyoming Meth 2011 more teens disapproved of experimental meth use (i.e. trying meth once or twice) in 2008 than 2011, and both experimental and regular use of heroin, marijuana and cocaine. In Colorado Meth 2011 disapproval of experimental use of marijuana decreased but disapproval of regular use increased from 2009 to 2011. In Georgia Meth 2011 most 12 to 17-year-olds disapproved of experimental use of meth, heroin and cocaine in 2011 than in 2010. In Hawaii Meth 2011 more 12 to 17-year-olds disapproved experimental use of meth in 2009 than in 2011. Most 18 to 24-year-olds disapproved of experimental and regular use of meth and experimental use of heroin and cocaine. In Idaho Meth 2010 more teens disapproved of experimental and regular use of meth, heroin and cocaine in 2007 than in 2010

\section{Knowledge about the effects of illicit drugs on health}

One RCT measured this outcome, finding a possible association between the effectiveness of the campaign and message on individual characteristics. One study shows significant improvement in knowledge about the target substance in the experimental group. Lee 2010 found an association between contemplation for change and marijuana use at three-month follow-up. Intervention participants who were higher in contemplation for change showed a significant decrease in marijuana use. Nevertheless, this result was not confirmed at six months follow-up. Newton 2010 showed that at the 12-month follow-up, significant improvements in alcohol and cannabis knowledge in students in the intervention group compared to the control group were present.

\section{Understanding of intended message and objectives}

Only one RCT addressed this outcome:Fishbein 2002 which adopted a measure of perceived effectiveness of a media campaign.

\section{Perceptions (including perception of peer norms and perception of risks of use of illicit drugs)}

This outcome was measured by 11 studies $(N=40,243)$ : four RCTs, one prospective cohort study, one CBA and five ITS.

Only one of the four included RCTs found a significant effect in favour of media campaigns in changing towards a negative perception of marijuana use (Zhao 2006). The remainder found weaker results apparently in favour of interventions.

Fishbein 2002 adopted a measure of perceived effectiveness of media campaign based on realism, learning and emotional responses, all considered highly correlated with effective messages. Zhao 2006 found that students exposed to media campaign messages showed changes towards a negative perception about the consequences of marijuana use. Schwinn 2010 measured the normative belief among participants and found a change in the experimental group which was not maintained at six months follow-up. As already mentioned Yzer 2003 targeted the belief that marijuana is a gateway to stronger drugs. Results did not support this and no clear persuasion was found for any of the ad sequences. In comparison to the control condition, adolescents in the explicit gateway condition tended to agree less with the gateway message and displayed weaker correlations between anti-marijuana beliefs and their attitude toward marijuana use.

Hornik 2006, the only prospective cohort study investigating this outcome, found a small but significant increase in anti-marijuana beliefs and attitudes in students exposed to media campaigns yet this was not accompanied by significant parallel gains in intentions not to use, social norms or self efficacy

The only CBA(Miller 2000) found that the students enrolled in the experimental arm showed significantly higher perceived risks from substance use

Results differed considerably across the five included Meth Project studies. In Wyoming Meth 2011 perception of ease to acquire any of the examined drugs (meth, heroin, marijuana and cocaine) decreased from 2008 to 2011. More teens agreed with all of the 14 perceived risks attributed to meth and more teens disagreed with six out of the nine perceived benefits attributed to meth. In Colorado Meth 2011 more teens in 2011 than in 2009 agreed with nine of the 14 items concerning risks attributed to meth. In Georgia Meth 2011 perception of ease to acquire cocaine and heroin decreased from 2010 to 2011 among 12 to 17-year-olds. More teens agreed with all of the 14 perceived risks attributed to meth, and fewer teens agreed with five of the nine perceived benefits attributed to meth. Among 18 to 24 -year olds, more young adults agreed with seven of the 14 perceived risks attributed to meth, and fewer young adults agreed with six of the nine perceived benefits attributed to meth. In Hawaii Meth 2011 perception of ease to acquire heroin decreased from 2009 to 2011 among 12 to 17 -year-olds. The percentage of those who see a "great risk" in taking meth, heroin and cocaine decreased by around 10 points. More teens agree with 13 of the 14 perceived risks attributed to meth. Among 18 to 24-year-olds a reduction of perceived ease to acquire marijuana and cocaine was also described. In such an age group the percentage of those who see a "great risk" in taking meth, heroin and cocaine decreased by around 15 points. More young adults agreed with all of the 14 perceived risks attributed to meth and fewer young adults agreed with five of nine perceived benefits of meth. In Idaho Meth 2010 perception of risk in trying meth, heroin and cocaine once or twice increased from 2007 to 2010. More teens agreed with all of the 14 perceived risks attributed to meth and fewer teens agreed with all of the nine perceived benefits attributed to meth.

\section{Adverse effects}

- Reactance (i.e. a reaction to contradict the prevailing norms of rules)

Fishbein 2002 found that six out of 16 studied Public Service Advertisements (PSA) were judged by the young participants as not effective. In other words, adolescents viewing these six PSAs 
reported that they and their friends would be more likely to try or to use drugs, and would feel less confident about how to deal with situations involving drugs. Specifically negative correlations were found for the advertisement tackling marijuana $(\mathrm{r}=-0.52)$, those not specifying a drug or talking about drugs in general, also tended to be judged as ineffective, although this relationship was not significant $(r=-0.23)$. PSAs describing the "just say no" message tended to be judged as less effective $(r=-0.29)$. Yzer 2003 found that adolescents exposed to the "Gateway" message (explicitly saying that marijuana use led to use of hard drugs) considered this message less effective and were (although not statistically significantly) more positive towards marijuana use, while Hornik 2006 found a possible presence of pro-marijuana effects in at least two analyses out of 10 in terms of intention to use and initiation.

- Positive descriptive norms (i.e. increased perception that drug use in peer population is common, normal or acceptable)

Palmgreen 2001 found a reinforcing effect of the media campaign on pro-marijuana beliefs (particularly for occasional use).

\section{I SCUSSION}

\section{Summary of main results}

The studies included in this review tested an array of different interventions including national campaigns, public service advertisements, television messages, video tapes and Internet-based campaigns and the effects were measured by means of unpublished and published scales administered to the participating adolescents. Hence the first issue is the comparability of results.

Overall 15 studies measured the effects on the use of drugs of nine campaigns of which four used the Internet, one was performed in school setting and four were TV broadcasting campaigns (the Meth Project was assessed by five studies and the National Youth Anti-Drug Media Campaign (NYADMC) was assessed at different stages by five studies).

The outcomes on the use of drugs of five randomised controlled trials (RCTs) (four on Internet-based interventions and one on $\mathrm{TV} /$ radio broadcasting) have been pooled, resulting in no effect of mass media campaigns (standardised mean difference (SMD) $0.02 ; 95 \%$ confidence interval (CI) -0.15 to 0.12 ), with statistically significant heterogeneity $(\mathrm{P}=0.02)$. The four studies including Internet-based interventions gave contrasting results about drug use (some showed that the intervention reduced the use of drugs and some showed that the intervention could favour use), whereas the study on the national campaigns found a reduction in use in the experimental group.

The study evaluating the school media campaign found a nonsignificant reduction in drug use in the experimental group.

The studies evaluating the Meth Project on methamphetamine were included in a separate meta-analysis, the pooled results of which showed a significant reduction in the past-year use of methamphetamine.

Five studies evaluated different phases of the NYADMC. The preliminary study showed positive results in favour of the campaign, the two studies evaluating the 1st phase showed an opposite effect, with a significant increase in drug use in the more robust study, and the two studies evaluating the 2 nd phase showed positive results in favour of the campaign.

There are a series of observational studies, generally cohort studies or interrupted time series (ITS), which can be classified as field trials and evaluate the effectiveness of the multimedia-TV campaigns intervention in its context. They show contrasting results, from weakly effective, as for the Meth Project campaign, to clearly harmful, as one form (Hornik 2006) reported statistically significant results in favour of the control group, showing an increase in marijuana use of $20 \%$ in those more exposed to the campaign compared to those less exposed. The multistage evaluation of the NYADMC campaign conducted to positive results.

Looking at the secondary outcomes, the RCTs included in the meta-analysis showed non-significant results in favour of the groups exposed to the campaign for intention to use, an outcome considered a proxy for future behavior (Litchfield 2006; Olds 2005). One observational study (Hornik 2006) found a possible reinforcing effect of media campaign exposure on intention to use, especially cannabis.

Summing up the available evidence from RCTs shows that media campaigns based on the Internet are not effective in reducing the use of drugs, whereas the evidence from observational studies shows that there are some positive effects in reducing last-year prevalence in younger people. A study based on independent data collection gave overall positive results for girls and showed no effectiveness in boys in terms of marijuana use.

\section{Overall completeness and applicability of evidence}

The objective of this review was to measure the effect of media campaigns on influencing drug use among young people. The studies we included only partially answer the question and they are hardly comparable. In fact the studies focused on a variety of interventions and used several different scales to measure the outcomes. It was therefore not possible to have results on all the typologies of campaign listed in the introduction section, and any attempt to compare effects is limited.

A second threat to the applicability of results is the nature of the studies: the RCTs are always carried out in an experimental context such as, for example, schools in which the students randomised to the intervention arm are exposed to the media message, or the trials enrolling volunteers on the Internet, a very selected population. This appears to measure efficacy and not effectiveness of the intervention, given that subjects are out of the context in which they would be exposed in the real world. The other studies, called 
field studies, measure the effect in a real context, but are limited in numbers, overall methodological quality and are actually focused on two campaigns.

Furthermore, all the studies were conducted in the USA, apart from two in Canada and Australia, and as a consequence the generalisability to other geographical and social contexts, such as Europe, remains unclear.

\section{Quality of the evidence}

We included 23 studies on very different interventions, the effects of which were measured with several scales. The methodological quality of the included studies was hard to assess as many dimensions were unclear in the relevant publications. Nevertheless, when the dimensions were reported the quality of the studies was acceptable. In many cases further information was obtained by contacting the study authors. The main limitation of the evidence available is the lack of comparability of some measures of outcomes and, more importantly, the unclear causal relationship between the campaign size and its effect. This lack of clarity reduces the generalisability of results, i.e. it is still unclear which part of a campaign should be reproduced to achieve which results.

\section{Potential biases in the review process}

The inclusion of studies which are different from randomised controlled trials complicates the identification and retrieval of the studies, due to a less structured indexing of studies in different databases, and lack of devoted registries and unique identification of studies. We therefore acknowledge that we might have missed some studies. Nevertheless, an accurate cross-check of all the reference lists and contacts with the principal investigators in the field may have reduced this risk.

The assessment of study quality relied on study design-specific checklists, yet for many publications the majority of the information we used assess and score the quality criteria was unclear. We therefore contacted many authors to ask for clarification, but in the case of the older studies it was not possible to retrieve additional information.

\section{Agreements and disagreements with other studies or reviews}

Werb and colleagues (Werb 2011) performed a systematic review of all the studies assessing public service announcements (eight studies) including meta-analyses for two outcomes: intention to use and and mean use of illicit drugs. In spite of different inclusion criteria (as we also included non-PSA interventions) and criteria for analysis, we reached similar conclusions. Furthermore, Wakefield 2010, in their broader analysis of media campaigns aiming to change health behaviour, address the media campaign effect on illicit drugs use with five studies, concluding that the relevant evidence is inconclusive.

\section{AUTHORS, CONCLUSIONS}

\section{Implications for practice}

The effectiveness of media campaigns to prevent illicit drug use among young people is not clearly supported, with some evidence of iatrogenic effects. Therefore it is recommended that such campaigns should only be provided in the context of rigorous, welldesigned and well-powered evaluation studies.

\section{Implications for research}

The great majority of the studies are conducted in the United States, thus more worldwide studies should be carried out. Moreover, validated and standardised tools to measure the outcome are recommended to allow comparability and generalisability of results. As the actual evidence suggests some effectiveness in specific populations (younger and female, for example) we need to focus better on investigation of the components of media campaigns which are effective in specific populations.

For this reason, beyond the general methodological recommendations, we suggest a strategy to make the best use of available resources and study designs. Our suggestions initially consider general improvement of methods:

- field evaluation studies should adopt, whenever possible, a cohort design;

- studies should be conducted in different countries and contexts;

- validated, comparable and standard tools should be used for the measurement of effects;

- the separate testing of specific media campaign components for their efficacy should be carried out by pilot randomised controlled trials in specific populations;

- future studies should ensure consistency among hypothesis testing, study design and measures of outcomes.

In general, whenever possible, interrupted time series studies, using independent and current data collection (such as the one by Carpenter 2011), should be conducted to assess the overall effects of any anti-drug media campaign.

Until the development of this research is ensured, we should not exclude the possibility of a campaign having iatrogenic effects. 


\section{ACKNOWLEDG EMENTS}

We would like to thank Gregor Burkhart and V. Anna Gyamathy for collaborating in conceiving the protocol for this review. We are grateful to Jennifer Stagnaro, Joan Polansky, John Horan, Ling Fang, Marco Yzer, Michael Slater, Nicola Newton, Philip Palmgreen and Violeta Taneva for providing us with useful advice and, whenever possible, with their studies' unpublished data.

\section{R E F R E NCES}

\section{References to studies included in this review}

Carpenter 2011 \{published data only\}

Carpenter CS, Pechmann C. Exposure to the Above the Influence antidrug advertisements and adolescent marijuana use in the United States, 2006-2008. American Journal of Public Health 2011;101(5):948-54. [PUBMED: 21421952]

Colorado Meth 2011 \{published and unpublished data\} Colorado Meth: Use \& Attitudes Survey 2011. The Meth Project 2011.

Czyzewska 2007 \{published data only\} Czyzewska M, Ginsburg HJ. Explicit and implicit effects of anti-marijuana and anti-tobacco TV advertisements. Addictive Behaviors 2007;32(1):114-27. [PUBMED: 16675148]

Fang 2010 \{published data only\}

Fang L, Schinke SP, Cole KC. Preventing substance use among early Asian-American adolescent girls: initial evaluation of a web-based, mother-daughter program. Journal of Adolescent Health 2010;47(5):529-32. [PUBMED: 20970090]

Fishbein 2002 \{published data only\} Fishbein M, Hall-Jamieson K, Zimmer E, von Haeften I, Nabi R. Avoiding the boomerang: testing the relative effectiveness of antidrug public service announcements before a national campaign. American Journal of Public Health 2002;92(2):238-45. [PUBMED: 11818299]

Georgia Meth 2011 \{published and unpublished data\} Georgia Meth: Use \& Attitudes Survey 2011. The Meth Project 2011.

Hawaii Meth 2011 \{published and unpublished data\} Hawaii Meth: Use \& Attitudes Survey 2011. The Meth Project 2011.

Hornik 2006 \{published data only\}

* Hornik R. Personal influence and the effects of the National Youth Anti-Drug Media Campaign. The ANNALS of the American Academy of Political and Social Science 2006; 608(1):282-300.

Hornik R, Jacobsohn L. The best laid plans: disappointments of the National Youth Anti-Drug Media
Campaign. LDI Issue Brief 2008;14(2):1-4. [PUBMED: 19288618]

Hornik R, Jacobsohn L, Orwin R, Piesse A, Kalton G. Effects of the National Youth Anti-Drug Media Campaign on youths. American Journal of Public Health 2008;98(12): 2229-36. [PUBMED: 18923126]

Orwin R, Cadell D, Chu A, Kalton G, Maklan D, Morin C, et al.Evaluation of the National Youth Anti-Drug Media Campaign: 2004 Report of Findings. Westat, 2006.

Idaho Meth 2010 \{published and unpublished data\}

* Idaho Meth: Use \& Attitudes Survey 2010. The Meth Project 2010.

Kelly 1992 \{published data only\}

Kelly K, Edwards R. Observations: Does discussion of advertising transform its effects? Yes...sometimes: A case among college students and their response to anti-drug advertising. Journal of Advertising Research 1992;32(4): 79-83.

\section{Lee 2010 \{published data only\}}

Lee CM, Neighbors C, Kilmer JR, Larimer ME. A brief, web-based personalized feedback selective intervention for college student marijuana use: a randomized clinical trial. Psychology of Addictive Behaviors 2010;24(2):265-73. [PUBMED: 20565152]

Miller 2000 \{published data only\} Miller WR, Toscova RT, Miller JH, Sanchez V. A theorybased motivational approach for reducing alcohol/drug problems in college. Health Education and Behavior 2000; 27(6):744-59. [PUBMED: 11104373]

Newton 2010 \{published and unpublished data\}

Newton NC, Andrews G, Teesson M, Vogl LE. Delivering prevention for alcohol and cannabis using the Internet: a cluster randomised controlled trial. Preventive Medicine 2009;48(6):579-84. [PUBMED: 19389420]

* Newton NC, Teesson M, Vogl LE, Andrews G. Internetbased prevention for alcohol and cannabis use: final results of the Climate Schools course. Addiction 2010;105(4): 749-59. [PUBMED: 20148791]

Palmgreen 1991 \{published data only\} Palmgreen P, Donohew L, Lorch EP, Rogus M, Helm D, Grant N. Sensation seeking, message sensation value, and drug use as mediators of PSA effectiveness. Health Communication 1991;3(4):217-27. 
Palmgreen 2001 \{published data only\}

* Palmgreen P, Donohew L, Lorch EP, Hoyle RH, Stephenson MT. Television campaigns and adolescent marijuana use: tests of sensation seeking targeting. American Journal of Public Health 2001;91(2):292-6. [PUBMED: 11211642]

Stephenson MT, Palmgreen P, Hoyle RH, Donohew L, Lorch EP, Colon SE. Short-term effects of an antimarijuana media campaign targeting high sensation seeking adolescents. Journal of Applied Communication Research 1999;27(3):175-95.

Polansky 1999 \{unpublished data only\} Polansky JM, Buki LP, Horan JJ, Ceperich SD, Burows DD. The effectiveness of substance abuse prevention videotapes with Mexican American adolescents. Hispanic Journal of Behavioral Sciences 1999;21(2):186-98.

Scheier 2010 \{published data only\}

Scheier LM, Grenard JL. Influence of a nationwide social marketing campaign on adolescent drug use. Journal of Health Communication 2010;15(3):240-71. [PUBMED: 20432107]

Schwinn 2010 \{published data only\}

Schwinn TM, Schinke SP, Di Noia J. Preventing drug abuse among adolescent girls: outcome data from an internetbased intervention. Prevention Science 2010;11(1):24-32. [PUBMED: 19728091]

Slater 2006 \{unpublished data only\} Slater MD, Kelly KJ, Edwards RW, Thurman PJ, Plested BA, Keefe TJ, et al.Combining in-school and communitybased media efforts: reducing marijuana and alcohol uptake among younger adolescents. Health Education Research 2006;21(1):157-67. [PUBMED: 16199491]

Slater 2011 \{published data only\} Slater MD, Kelly KJ, Lawrence FR, Stanley LR, Comello ML. Assessing media campaigns linking marijuana nonuse with autonomy and aspirations: "Be Under Your Own Influence" and ONDCP's "Above the Influence". Prevention Science 2011;12(1):12-22. [PUBMED: 21271357]

Wyoming Meth 2011 \{published and unpublished data\} Wyoming Meth: Use \& Attitudes Survey 2011. The Meth Project 2011.

Yzer 2003 \{unpublished data only\} Yzer MC, Cappella JN, Fishbein M, Hornik R, Ahern RK. The effectiveness of gateway communications in antimarijuana campaigns. Journal of Health Communication 2003;8(2):129-43. [PUBMED: 12746037]

Zhao 2006 \{published data only\} Zhao X, Sayeed S, Cappella J, Hornik R, Fishbein M, Ahern RK. Targeting norm-related beliefs about marijuana use in an adolescent population. Health Communication 2006;19 (3):187-96. [PUBMED: 16719722]

\section{References to studies excluded from this review}

Alemi 1996 \{published data only\}

Alemi F, Stephens RC, Javalghi RG, Dyches H, Butts J, Ghadiri A. A randomized trial of a telecommunications network for pregnant women who use cocaine. Medical Care 1996;34(10 Suppl):OS10-20. [PUBMED: 8843933]

An 2007 \{published data only\}

An S. Attitude toward direct-to-consumer advertising and drug inquiry intention: the moderating role of perceived knowledge. Journal of Health Communication 2007;12(6): 567-80. [PUBMED: 17763053]

Andrews 1995 \{published data only\}

Andrews AB, McLeese DG, Curran S. The impact of a media campaign on public action to help maltreated children in addictive families. Child Abuse and Neglect 1995; 19(8):921-32. [PUBMED: 7583751]

Barber 1990 \{published data only\}

Barber JJ, Grichting WL. Australia's media campaign against drug abuse. International Journal of the Addictions 1990;25 (6):693-708.

Beaudoin 2007 \{published data only\} Beaudoin CE, Thorson E. Evaluating the effects of a youth health media campaign. Journal of Health Communication 2007;12(5):439-54. [PUBMED: 17710595]

Beck 2008 \{published data only\}

Beck F, Legleye S, Obradovic I, Mutatayi C, Cohen B, Karila L. Drug use among youths [Les plus jeunes adolescents face aux drogues: reperage des usages problematiques et elements de reponse institutionnelle en France.]. Medecine Sciences: M/S 2008;24(8-9):758-67. [PUBMED: 18789225]

Belenko 2009 \{published data only\}

Belenko S, Dugosh KL, Lynch K, Mericle AA, Pich M, Forman RF. Online illegal drug use information: an exploratory analysis of drug-related website viewing by adolescents. Journal of Health Communication 2009;14(7): 612-30. [PUBMED: 19851914]

Black 1994 \{published data only\}

Black GS, Zastowny TR, Green PJ, Adams EH, Lawton $\mathrm{KB}$. The consistency of estimates obtained through centrallocation sampling: analysis of the Partnership for a DrugFree America Attitude Tracking Study. American Journal of Drug and Alcohol Abuse 1994;20(2):199-222.

Brannon 1989 \{published data only\} Brannon BR, Dent CW, Flay BR, Smith G, Sussman S, Pentz MA, et al.The television, school, and family project. $\mathrm{V}$. The impact of curriculum delivery format on program acceptance. Preventive Medicine 1989;18(4):492-502. [PUBMED: 2798371]

Chambers 2005 \{published data only\} Chambers M, Connor SL, McElhinney S. Substance use and young people: the potential of technology. Journal of Psychiatric and Mental Health Nursing 2005;12(2):179-86. [PUBMED: 15788035]

Chiauzzi 2008 \{published data only\} Chiauzzi E, Brevard J, Thum C, Decembrele S, Lord S. MyStudentBody-Stress: an online stress management intervention for college students. Journal of Health Communication 2008;13(6):555-72. [PUBMED: 18726812] 
Collins 1991 \{published data only\}

Collins D, Cellucci T. Effects of a school-based alcohol education program with a media prevention component. Psychological Reports 1991;69(1):191-7. [PUBMED: 1961790]

Cook 1999 \{published data only\}

Cook C. Book and media reviews. Addiction Biology 1999;4

(2):245-51. [PUBMED: 20575792]

David 2006 \{published data only\}

David C, Cappella Joseph N, Fishbein M. The social diffusion of influence among adolescents: group interaction in a chat room environment about antidrug advertisements. Communication Theory 2006;16(1):118-40.

DeJong 1999 \{published data only\} Dejong W, Wallack L. A critical perspective on the drug czar's antidrug media campaign. Journal of Health Communication 1999;4(2):155-60. [PUBMED: 10977283]

Di Noia 2003 \{published data only\}

Di Noia J, Schwinn TM, Dastur ZA, Schinke SP. The relative efficacy of pamphlets, CD-ROM, and the Internet for disseminating adolescent drug abuse prevention programs: an exploratory study. Preventive Medicine 2003; 37(6 Pt 1):646-53. [PUBMED: 14636798]

Donohew 2000 \{published data only\}

Donohew L, Zimmerman R, Cupp PS, Novak S, Colon $S$, Abell R. Sensation seeking, impulsive decision-making, and risky sex: implications for risk-taking and design of interventions. Personality and Individual Differences 2000; 28(6):1079-91.

Epstein 1999 \{published data only\}

Epstein J, McGaha AC. ATOD-TV: evaluation of a multimedia program designed to educate the public about substance abuse. Computers in Human Behavior 1999;15 (1):73-83.

Erceg-Hurn 2008 \{published and unpublished data\} Montana Meth: Use \& Attitudes Survey 2008. The Meth Project 2008.

* Erceg-Hurn DM. Drugs, money, and graphic ads: a critical review of the Montana Meth Project. Prevention Science 2008;9(4):256-63. [PUBMED: 18686033]

Everett 1995 \{published data only\}

Everett MW, Palmgreen P. Influences of sensation seeking, message sensation value, and program context on effectiveness of anticocaine public service announcements. Health Communication 1995;7(3):225-48.

Flay 2000 \{published data only\}

Flay BR. Approaches to substance use prevention utilizing school curriculum plus social environment change. Addictive Behaviors 2000;25(6):861-85.

Hannon 2000 \{published data only\}

Hannon SW. Background and principles of an African American targeted national anti-drug campaign. Journal of Public Health Management and Practice 2000;6(3):65-71. [PUBMED: 10848485]
Harrington 2003 \{published data only\}

Harrington NG, Lane DR, Donohew L, Zimmerman RS, Norling GR, An JH, et al.Persuasive strategies for effective anti-drug messages. Communication Monographs 2003;70 (1):1-1.

Helme 2007 \{published data only\}

Helme DW, Donohew RL, Baier M, Zittleman L. A classroom-administered simulation of a television campaign on adolescent smoking: testing an activation model of information exposure. Journal of Health Communication 2007;12(4):399-415. [PUBMED: 17558790]

Johnson 1990 \{published data only\}

Johnson CA, Pentz MA, Weber MD, Dwyer JH, Baer N, MacKinnon DP, et al.Relative effectiveness of comprehensive community programming for drug abuse prevention with high-risk and low-risk adolescents. Journal of Consulting and Clinical Psychology 1990;58(4):447-56. [PUBMED: 2212182]

Jordan 2005 \{published data only\} Jordan S. www.drugcom.de--an Internet based information and counselling project for the prevention of addiction [www.drugcom.de--ein Informations- und Beratungsangebot zur Suchtpravention im Internet.]. Praxis der Kinderpsychologie und Kinderpsychiatrie 2005;54(9): 742-54. [PUBMED: 16305021]

Kang 2009 \{published data only\}

Kang Y, Cappella JN, Fishbein M. The effect of marijuana scenes in anti-marijuana public service announcements on adolescents' evaluation of ad effectiveness. Health Communication 2009;24(6):483-93. [PUBMED: 19735026]

Know the Score 2007 \{published data only\}

Binnie I, Kinver A, Lam P. Know the Score: Cocaine Wave 3 - 2005/06 Post-Campaign Evaluation. Scottish Executive Social Research, June 2006.

Phillips R, Kinver A. Know the Score: Cocaine Wave 4 2006/07 Post-campaign Evaluation. Scottish Executive Social Research, February 2007.

TNS System Three. Know the Score - Heroin 2005 Preand Post-Campaign Evaluation. Scottish Executive Social Research, 2006.

TNS System Three. Know the Score: Anti-Heroin 2006/07 Campaign Evaluation. Scottish Executive Social Research, 2006.

Lorch 1994 \{published data only\} Lorch EP, Palmgreen P, Donohew L, Helm D, Baer SA, Dsilva MU. Program context, sensation seeking, and attention to televised anti-drug public service announcements. Human Communication Research 1994;20 (3):390-412.

Lubman 2007 \{published data only\} Lubman DI, Hides L, Yucel M, Toumbourou JW. Intervening early to reduce developmentally harmful substance use among youth populations. Medical Journal of Australia 2007;187(7 Suppl):S22-5. [PUBMED: 17908020]

Media campaigns for the prevention of illicit drug use in young people (Review)

Copyright @ 2013 The Cochrane Collaboration. Published by John Wiley \& Sons, Ltd. 
Marsiglia 2009 \{published data only\}

Marsiglia FF, Kulis S, Rodriguez GM, Becerra D, Castillo J. Culturally specific youth substance abuse resistance skills: applicability across the U.S.-Mexico border. Research on Social Work Practice 2009;19(2):152-64. [PUBMED: 19924268]

Myers 2006 \{published data only\}

Myers K, Valentine J, Morganthaler R, Melzer S. Telepsychiatry with incarcerated youth. Journal of Adolescent Health 2006;38(6):643-8. [PUBMED: 16730590]

Palmgreen 2007 \{published data only\}

Palmgreen P, Lorch EP, Stephenson MT, Hoyle RH, Donohew L. Effects of the Office of National Drug Control Policy's Marijuana Initiative Campaign on high-sensationseeking adolescents. American Journal of Public Health 2007;97(9):1644-9. [PUBMED: 17395843]

Pentz 1990 \{published data only\}

Pentz MA, Trebow EA, Hansen WB, MacKinnon DP, Dwyer JH, Johnson CA, et al.Effects of program implementation on adolescent drug use behavior: the Midwestern Prevention Project (MPP). Evaluation Review 1990;14(3):264-89.

Ramirez 1999 \{published data only\}

Ramirez AG, Gallion KJ, Espinoza R, Chalela P. Developing a media- and school-based program for substance abuse prevention among Hispanic youth: a case study of Mirame!/ Look at Me!. Nicotine and Tobacco Research 1999;1 Suppl 1:S99-104. [PUBMED: 11072412]

Reis 1994 \{published data only\}

Reis EC, Duggan AK, Adger HJ, DeAngelis C. The impact of anti-drug advertising. Perceptions of middle and high school students. Archives of Pediatrics \& Adolescent Medicine 1994;148(12):1262-8. [PUBMED: 7951804]

Ruggiero 2006 \{published data only\}

Ruggiero KJ, Resnick HS, Acierno R, Coffey SF, Carpenter MJ, Ruscio AM, et al.Internet-based intervention for mental health and substance use problems in disaster-affected populations: a pilot feasibility study. Behavior Therapy 2006;37(2):190-205. [PUBMED: 16942971]

Schmeling 1980 \{published data only\}

Schmeling DG, Wotring CE. Making anti-drug-abuse advertising work. Journal of Advertising Research 1980; Vol. 20, issue 3:33-7.

Siegel 2008 \{published data only\} Siegel JT, Alvaro EM, Crano WD, Skenderian J, Lac A, Patel N. Influencing inhalant intentions by changing socio-personal expectations. Prevention Science 2008;9(3): 153-65. [PUBMED: 18543103]

Skinner 1995a \{published data only\} Skinner ER, Slater MD. Family communication patterns, rebelliousness, and adolescent reactions to anti-drug PSAs. Journal of Drug Education 1995;25(4):343-55.

Sloboda 2006 \{published data only\}

Sloboda Z, Bukoski WJ (editors). Handbook of Drug Abuse Prevention. Boston, MA: Springer US, 2006. [: 9780387354088]
Spitzer 2010 \{published data only\}

Spitzer JE. Above the Influence: a Value Analysis of Anti-drug Public Service Announcements. ProQuest Dissertation, 2010. [: 750165158; : 9781124200040]

Stephenson 2002 \{published data only\} Stephenson MT, Morgan SE, Lorch EP, Palmgreen P, Donohew L, Hoyle RH. Predictors of exposure from an antimarijuana media campaign: outcome research assessing sensation seeking targeting. Health Communication 2002; 14(1):23-43. [PUBMED: 11853208]

Stephenson 2002a \{published data only\} Stephenson MT. Sensation seeking as a moderator of the processing of anti-heroin PSAs. Communication Studies 2002;53(4):358-80.

Stephenson 2003 \{published data only\} Stephenson MT. Examining adolescents' responses to antimarijuana PSAs. Human Communication Research 2003;29(3):343-69.

Stephenson 2005 \{published data only\} Stephenson MT, Quick BL. Parent ads in the National Youth Anti-Drug Media Campaign. Journal of Health Communication 2005;10(8):701-10. [PUBMED: 16316934]

Stevens 1996 \{published data only\} Stevens MM, Freeman DHJ, Mott L, Youells F. Three-year results of prevention programs on marijuana use: the New Hampshire study. Journal of Drug Education 1996;26(3): 257-73. [PUBMED: 8952210]

Stryker 2003 \{published data only\}

Stryker JE. Media and marijuana: A longitudinal analysis of news media effects on adolescents' marijuana use and related outcomes, 1977-1999. Journal of Health Communication 2003;8(4):305-28. [PUBMED: 12907398]

Sussman 1987 \{published data only\} Sussman S, Flay BR, Sobel JL, Rauch JM, Hansen WB, Johnson CA. Viewing and evaluation of a televised drug education program by students previously or concurrently exposed to school-based substance abuse prevention programming. Health Education Research 1987;2(4): 373-83.

Tait 2010 \{published data only\} Tait RJ, Christensen H. Internet-based interventions for young people with problematic substance use: a systematic review. Medical Journal of Australia 2010;192(11 Suppl): S15-21. [PUBMED: 20528701]

Taylor 1984 \{published data only\} Taylor RL, Lam DJ, Roppel CE, Barter JT. Friends can be good medicine: an excursion into mental health promotion. Community Mental Health Journal 1984;20(4):294-303. [PUBMED: 6518742]

Varshavsky 2003 \{published data only\} Varshavsky T. Media drug prevention and public service advertising: evaluating The National Youth Anti-Drug Media Campaign. Communication and Media Studies Senior Thesis 2003. 
Werch 2010 \{published data only\}

Werch CE, Bian H, Diclemente CC, Moore MJ, Thombs D, Ames SC, et al.A brief image-based prevention intervention for adolescents. Psychology of Addictive Behaviors 2010;24 (1):170-5. [PUBMED: 20307126]

\section{References to studies awaiting assessment}

Block 2002 \{unpublished data only\} Block LG, Morwitz VG, Putsis WPJ, Sen SK. Assessing the impact of antidrug advertising on adolescent drug consumption: results from a behavioral economic model. American Journal of Public Health 2002;92(8):1346-51. [PUBMED: 12144995]

Duncan 2000 \{published and unpublished data\} Duncan TE, Duncan SC, Beauchamp N, Wells J, Ary DV. Development and evaluation of an interactive CDROM refusal skills program to prevent youth substance use: "refuse to use". Journal of Behavioral Medicine 2000;23(1): 59-72. [PUBMED: 10749011]

Flay 1986 \{published data only\}

Flay BR. Mass media linkages with school-based programs for drug abuse prevention. Journal of School Health 1986;56 (9):402-6. [PUBMED: 3537525]

Longshore 2006 \{published and unpublished data\} Longshore D, Ghosh-Dastidar B, Ellickson PL. National Youth Anti-Drug Media Campaign and school-based drug prevention: Evidence for a synergistic effect in ALERT Plus. Addictive Behaviors 2006;31(3):496-508. [PUBMED: 15979245]

Marsch 2007 \{published data only\}

Marsch LA, Bickel WK, Grabinski MJ. Application of interactive, computer technology to adolescent substance abuse prevention and treatment. Adolescent Medicine: State of the Art Reviews 2007;18(2):342-56, xii. [PUBMED: 18605650]

Moore 2011 \{published data only\}

Moore LS. After Six Years...: an Examination of the Effectiveness of the Above The Influence Campaign on Its Initial Target Audience (Master's thesis). Retrieved from ProQuest Dissertations \& Theses A\&I, 2011. [: UMI 1505413]

Moreno 2009 \{published and unpublished data\} Moreno MA, Vanderstoep A, Parks MR, Zimmerman FJ, Kurth A, Christakis DA. Reducing at-risk adolescents' display of risk behavior on a social networking web site: a randomized controlled pilot intervention trial. Archives of Pediatrics and Adolescent Medicine 2009;163(1):35-41. [PUBMED: 19124701]

Skinner 1995 \{published data only\}

Skinner ER, Slater MD. Family communication patterns, rebelliousness, and adolescent reactions to anti-drug PSAs. Journal of Drug Education 1995;25(4):343-55. [PUBMED: 8907405]

Williams 2005 \{published and unpublished data\} Williams C, Griffin KW, Macaulay AP, West TL, Gronewold E. Efficacy of a drug prevention CD-ROM intervention for adolescents. Substance Use and Misuse 2005;40(6):869-78.

[PUBMED: 15974146]

\section{Additional references}

\section{Ajzen 1991}

Ajzen I. The theory of planned behavior. Organizational Behavior and Human Decision Processes 1991;50:179-211.

\section{Ashton 2003}

Ashton B. The American Star comes to England. Drug and Alcohol Findings 2003;8:21-6.

Bandura 1977

Bandura A. Social Learning Theory. New York: General Learning Press, 1977.

Battjes 1985

Battjes RJ. Prevention of adolescent drug abuse. International Journal of the Addictions 1985;20(6-7): 1113-34. [PUBMED: 2416701]

Berberian 1976

Berberian RM, Gross C, Lovejoy J, Paparella S. The effectiveness of drug education programs: a critical review. Health Education Monographs 1976;4(4):377-98. [PUBMED: 1010754]

\section{Berkowitz 2004}

Berkowitz A. The Social Norms Approach: Theory, Research, and Annotated Bibliography. http:// www.alanberkowitz.com/articles/social norms.pdf 2004.

Brinn 2010

Brinn MP, Carson KV, Esterman AJ, Chang AB, Smith BJ, Sowden AJ. Mass media interventions for preventing smoking in young people. Cochrane Database of Systematic Reviews 2010, Issue 11. [DOI: 10.1002/ 14651858.CD001006.pub2]

Bühler 2006

Bühler A, Kröger C. Expertise zur Prävention des Substanzmissbrauchs (Forschung und Praxis der Gesundheitsförderung Band 29). Köln: Bundeszentralefür gesundheitliche Aufklärung BZgA, 2006.

Camí 2003

Camí J, Farré M. Drug addiction. New England Journal of Medicine 2003;348(10):975-86. [DOI: 10.1056/ NEJMra023160]

Crano 2001

Crano WD, Burgoon M, Oskamp S. Mass Media and Drug Prevention: Classic and Contemporary Theories and Research. Mahwah, New Jersey: Lawrence Erlbaum Associates, 2001.

\section{EMCDDA 2009}

European Monitoring Centre for Drugs and Drug Addiction. 2009 Annual Report on the State of the Drugs Problem in Europe. Publications Office of the European Union, November 2009.

\section{EMCDDA 2010}

European Monitoring Centre for Drugs and Drug Addiction. The State of the Drugs Problem in Europe. Luxembourg: Publications Office of the European Union, 2010. [DOI: $10.2810 / 33349$; : 978-92-9168-432-8] 


\section{ESPAD 2011}

Hibell B, Guttormsson U, Ahlström S, Balakireva O, Bjarnason T, Kokkevi A, et al.The 2011 ESPAD Report Substance Use Among Students in 36 European Countries. Stockholm: Swedish Council for Information on Alcohol and other Drugs, European Monitoring Centre for Drugs and Drug Addiction, 2012.

Faggiano 2008

Faggiano F, Vigna-Taglianti FD, Versino E, Zambon A, Borraccino A, Lemma P. School-based prevention for illicit drugs use: a systematic review. Preventive Medicine 2008;46 (5):385-96. [PUBMED: 18258289]

\section{Flay 1983}

Flay BR, Sobel JL. The role of mass media in preventing adolescent substance abuse. Preventing Adolescent Drug Abuse Intervention Strategies. NIDA Research Monograph 47, 1983.

\section{Gilmour 2006}

Gilmour S, Degenhardt L, Hall W, Day C. Using intervention time series analyses to assess the effects of imperfectly identifiable natural events: a general method and example. BMC Medical Research Methodology 2006;6: 16. [PUBMED: 16579864 ]

\section{Glanz 2002}

Glanz K, Rimer BK, Lewis FM. Health Behavior and Health Education. Theory, Research and Practice. San Francisco: Wiley \& Sons, 2002.

Hailey 2008

Hailey D, Roine R, Ohinmaa A. The effectiveness of telemental health applications: a review. Canadian Journal of Psychiatry. Revue Canadienne de Psychiatrie 2008;53(11): 769-78. [PUBMED: 19087471]

\section{Hawks 2002}

Hawks D. A Selected Review of What Works in the Area of Prevention. World Health Organization, 2002.

\section{Higgins 2011}

Higgins JPT, Green S (editors). Cochrane Handbook for Systematic Reviews of Interventions Version 5.1.0 [updated March 2011]. The Cochrane Collaboration, 2011. Available from www.cochrane-handbook.org 2011.

\section{Hornik 2008}

Hornik R, Jacobsohn L. The best laid plans: disappointments of the National Youth Anti-Drug Media Campaign. Leonard Davis Institute Issue Brief 2008;14(2): $1-4$.

\section{Kumpfer 2008}

Kumpfer KL, Smith P, Summerhays JF. A wakeup call to the prevention field: are prevention programs for substance use effective for girls?. Substance Use and Misuse 2008;43(8-9): 978-1001. [PUBMED: 18649225]

\section{Leshner 1997}

Leshner AI. Drug abuse and addiction treatment research: the next generation. Archives of General Psychiatry 1997;54: 691-4. [DOI: 10.1001/archpsyc. 1997.01830200015002$]$

\section{Leshner 1999}

Leshner AI. Science-based views of drug addiction and its treatment. JAMA 1999;282(14):1314-6. [DOI: 10.1001/ jama.282.14.1314]

\section{Litchfield 2006}

Litchfield RA, White KM. Young adults' willingness and intentions to use amphetamines: An application of the theory of reasoned action. E-Journal of Applied Psychology 2006;2(1):1-9.

\section{McGrath 2006}

McGrath Y, Sumnall H, McVeigh J, Bellis M. Drug Use Prevention Among Young People: A Review Of Reviews. Evidence Briefing Update. Health Development Agency (HDA), 2006.

\section{McLelland 2000}

McLelland T, Lewis DC, O’Brien CP, Kleber HD. Drug dependence, a chronic medical disease: Implications for treatment, insurance and outcome evaluation. JAMA 2000; 284:1689-95. [PUBMED: 11015800]

\section{Moskowitz 1983}

Moskowitz JM. Preventing adolescent substance abuse through drug education. Preventing Adolescent Drug Abuse Intervention Strategies. NIDA Research Monograph 47, 1983.

\section{NCI 2008}

National Cancer Institute. The Role of the Media in Promoting and Reducing Tobacco Use. Vol. 19, Bethesda, MD: U.S. Department of Health and Human Services, National Institutes of Health, National Cancer Institute, 2008. [: NIH Pub. No. 07-6242]

\section{Nestler 1997}

Nestler EJ, Aghajanian GK. Molecular and cellular basis of addiction. Science 1997;278:58-63. [DOI: 10.1126/ science.278.5335.58]

\section{Olds 2005}

Olds RS, Thombs DL, Tomasek JR. Relations between normative beliefs and initiation intentions toward cigarette, alcohol and marijuana. Journal of Adolescent Health 2005; 37(1):75. [PUBMED: 15963910]

\section{Perkins 1986}

Perkins HW, Berkowitz AD. Perceiving the community norms of alcohol use among students: some research implications for campus alcohol education programming. International Journal of the Addictions 1986;21(9-10): 961-76.

\section{Redman 1990}

Redman S, Spencer EA, Sanson-Fisher RW. The role of mass media in changing health-related behaviour: a critical appraisal of two models. Health Promotion International 1990;5:85-101. [DOI: 10.1093/heapro/5.1.85]

\section{Review Manager 2012}

The Nordic Cochrane Centre, The Cochrane Collaboration. Review Manager (RevMan). 5.2. Copenhagen: The Nordic Cochrane Centre, The Cochrane Collaboration, 2012. 


\section{Romer 1994}

Romer D. Using mass media to reduce adolescent involvement in drug trafficking. Pediatrics 1994;93(6 Pt 2): 1073-7. [PUBMED: 8197010]

\section{Romer 1995}

Romer D, Kim S. Health interventions for African American and Latino youth: the potential role of mass media. Health Education Quarterly 1995;22(2):172-89. [PUBMED: 7622386]

Rossi 2003

Rossi PH, Freeman HE. Evaluation: A Systematic Approach. 7th Edition. Newbury Park: Sage Publications, Inc, 2003.

\section{Schilling 1990}

Schilling RF, McAlister AL. Preventing drug use in adolescents through media interventions. Journal of Consulting and Clinical Psychology 1990;58(4):416-24. [PUBMED: 2212178]

\section{Stephenson 2003b}

Stephenson MT. Mass media strategies targeting high sensation seekers: what works and why. American Journal of Health Behavior 2003;27 Suppl 3:S233-8. [PUBMED: 14672384]

\section{Strasburger 2008}

Strasburger VC, Wilson BJ, Jordan AB. Children, Adolescents, and the Media. 2nd Edition. Sage Publications, 2008.

Sumnall 2007

Sumnall HR, Bellis MA. Can health campaigns make people ill? The iatrogenic potential of population-based cannabis prevention. Journal of Epidemiology and Community Health 2007;61(11):930-1. [DOI: 10.1136/jech.2007.060277]

\section{Swendsen 2009}

Swendsen J, Conway KP, Degenhardt L, Dierker L, Glantz $\mathrm{M}$, Jin $\mathrm{R}$, et al.Socio-demographic risk factors for alcohol and drug dependence: the 10-year follow-up of the national comorbidity survey. Addiction 2009;104(8):1346-55.

[DOI: $10.1111 /$ j.1360-0443.2009.02622.x]

\section{UNODC 2012}

UNODC. World Drug Report 2012. E.12.XI.1. Vienna: United Nations, 2012.

\section{Wakefield 2010}

Wakefield MA, Loken B, Hornik RC. Use of mass media campaigns to change health behaviour. Lancet 2010;376: 1261-71. [DOI: 10.1016/S0140-6736(10)60809-4]

\section{Wammes 2007}

Wammes A, Van Leeuwen, Lokman S. Evaluatierapport DVP-Campagne 2006 'Je bent niet gek als jeniet blowt'. Utrecht: Trimbos Institute, 2007.

\section{Werb 2011}

Werb D, Mills EJ, Debeck K, Kerr T, Montaner JS, Wood E. The effectiveness of anti-illicit-drug public-service announcements: a systematic review and meta-analysis. Journal of Epidemiology and Community Health 2011;65 (10):834-40. [PUBMED: 21558482]

\section{Wise 1998}

Wise RA. Drug-activation of brain reward pathways. Drug and Alcohol Dependence 1998;51:13-22.

* Indicates the major publication for the study 


\section{CHARACTERISTICS OF STUDIES}

\section{Characteristics of included studies [ordered by study ID]}

\section{Carpenter 2011}

Methods

Study design: interrupted time series study

Sampling: systematic sampling (schools are selected within geographic areas that are determined by the sampling section of the University of Michigan Survey Research

Center, page 949)

Comparison group(s): pre-intervention surveys

Follow-up duration: n/a

Study time span: 2006 to 2008 (approximately 36 months)

\begin{tabular}{|c|c|c|}
\hline Participants & \multicolumn{2}{|c|}{130,245 youths from 8 th to 12 th grade (13- to 18 -year-old) } \\
\hline Interventions & \multicolumn{2}{|c|}{$\begin{array}{l}\text { All media for } 210 \text { media markets for } 2006 \text { to 2008, after the introduction of the Above } \\
\text { the Influence campaign }\end{array}$} \\
\hline Outcomes & \multicolumn{2}{|c|}{$\begin{array}{l}\text { - Past 30-day marijuana use } \\
\text { - Lifetime marijuana use } \\
\text { - Past-month alcohol consumption }\end{array}$} \\
\hline \multicolumn{3}{|l|}{ Notes } \\
\hline \multicolumn{3}{|l|}{ Risk of bias } \\
\hline Bias & Authors' judgement & Support for judgement \\
\hline $\begin{array}{l}\text { Random sequence generation (selection } \\
\text { bias) }\end{array}$ & Unclear risk & Not applicable \\
\hline Allocation concealment (selection bias) & Unclear risk & Not applicable \\
\hline $\begin{array}{l}\text { Blinding of outcome assessment (detection } \\
\text { bias) } \\
\text { All outcomes }\end{array}$ & Unclear risk & Not reported \\
\hline $\begin{array}{l}\text { Incomplete outcome data (attrition bias) } \\
\text { All outcomes }\end{array}$ & Unclear risk & Not reported \\
\hline Selective reporting (reporting bias) & Unclear risk & $\begin{array}{l}\text { No information regarding potential report- } \\
\text { ing bias }\end{array}$ \\
\hline
\end{tabular}


Colorado Meth 2011

Methods

Study design: interrupted time series study

Sampling: $\mathrm{n} / \mathrm{a}$

Comparison group(s): pre-intervention survey

Follow-up duration: n/a

Study time span: March 2009 to April 2011 (26 months)

Participants 1803 youths $(600+601+602)$

Interventions

Meth Project (USA), a "messaging campaign, supported by community outreach, and public policy initiatives". The campaign comprises "television, radio, print, billboard, and Internet advertising"

Outcomes

- Past-month use of methamphetamine

- Attitudes on methamphetamine and other drugs

- Perceptions concerning methamphetamine and other drugs

- Information sources and advertising awareness

- Statewide Meth Project awareness and perceptions

Notes

Risk of bias

\begin{tabular}{l|ll}
\hline Bias & Authors' judgement & Support for judgement \\
\hline $\begin{array}{l}\text { Random sequence generation (selection } \\
\text { bias) }\end{array}$ & Unclear risk & Not applicable \\
\hline $\begin{array}{l}\text { Allocation concealment (selection bias) } \\
\begin{array}{l}\text { Blinding of outcome assessment (detection } \\
\text { bias) } \\
\text { All outcomes }\end{array}\end{array}$ & Low risk & Not applicable \\
\hline $\begin{array}{l}\text { Incomplete outcome data (attrition bias) } \\
\text { All outcomes }\end{array}$ & Unclear risk & Anonymous questionnaires \\
\hline \begin{tabular}{l} 
Selective reporting (reporting bias) \\
\hline
\end{tabular} & Unclear risk & Not reported \\
\hline
\end{tabular}




\begin{tabular}{ll} 
Methods & Study design: randomised controlled trial \\
& Sampling: not specified \\
Comparison group $(s): 4=2$ anti-tobacco advertisements x 2 orders of advertisements (i. \\
e. explicit attitudes towards tobacco or marijuana) \\
$\begin{array}{l}\text { Follow-up duration: not applicable } \\
\text { Study time span: not specified }\end{array}$ \\
\hline Participants & 229 college students aged 18 to 19 years \\
\hline
\end{tabular}

15 advertisement embedded in a 15-minute science programme (USA). 10 advertisements were youth directed, 5 were non-youth directed. Each programme comprised of 90-second science film segments, 30-second youth-directed ad, 30-second non-youthdirected ad, then again another 30 -second youth-directed ad. There were 4 versions of recorded programme corresponding to 4 experimental conditions: 2 types of advertisements (i.e. anti-tobacco or anti-marijuana) x 2 orders of advertisements (i.e. explicit attitudes towards tobacco or marijuana)

\begin{tabular}{ll}
\hline Outcomes & - Implicit and explicit attitude towards tobacco \\
- Implicit and explicit attitude towards marijuana
\end{tabular}

\section{Risk of bias}

\begin{tabular}{|c|c|c|}
\hline Bias & Authors' judgement & Support for judgement \\
\hline $\begin{array}{l}\text { Random sequence generation (selection } \\
\text { bias) }\end{array}$ & Unclear risk & $\begin{array}{l}\text { p. } 117 \text { "They were randomly assigned to } \\
\text { experimental conditions", but randomisa- } \\
\text { tion details are not reported }\end{array}$ \\
\hline Allocation concealment (selection bias) & Low risk & $\begin{array}{l}\text { Although full allocation concealment is not } \\
\text { possible for this kind of study, there is low } \\
\text { risk of selection bias because researchers ad- } \\
\text { ministering the intervention were unlikely } \\
\text { to know the children. See p. 117: "Two } \\
\text { groups of } 18 \text { - to 19-year-old college stu- } \\
\text { dents were exposed to either anti-tobacco } \\
\text { or anti-marijuana advertisements followed } \\
\text { by implicit and explicit tests of attitudes to } \\
\text { both, marijuana and tobacco" }\end{array}$ \\
\hline
\end{tabular}

Blinding of outcome assessment (detection Low risk bias)

All outcomes

Incomplete outcome data (attrition bias) Low risk All outcomes
Anonymous questionnaire

p. 119 "Next to a computer, each person had a survey with a pre-recorded ID number on it"

All participants completed the test (being a post-only design); p. 117 "Two groups of 18- to 19-year-old college students were 
Czyzewska 2007 (Continued)

exposed to either anti-tobacco or anti-marijuana advertisements followed by implicit and explicit tests of attitudes to both, marijuana and tobacco"

Fang 2010

Methods

Study design: randomised controlled trial

Sampling: random sampling (through online advertisement and community service agencies)

Comparison group(s): no intervention

Follow-up duration: 6.25 months

Study time span: September 2007 to - December 2008 ( $\sim 16$ months)

Participants

108 Asian-American girls aged 10 to 14 with private access to a computer, and their mothers

Interventions

Internet-based prevention programme (USA) guided by family interaction theory and aiming to prevent girls' substance use through enhancing mother-daughter interactions. 9 sessions: mother-daughter relationship, conflict management, substance use opportunities, body image, mood management, stress management, problem solving, social influences, self efficacy. The programme was not designed expressly for Asian-Americans

Outcomes

Notes
- Past 30-day use of
o alcohol
$\circ$ cigarettes
- marijuana
$\circ$ prescription drugs

- Intention to use any of the above in the future

- Depression

- Other variables
- Self efficacy
- Refusal skills
- Mother-daughter closeness
- Mother-daughter communication
- Maternal monitoring
- Family rules against substance use

Only 1 post-test survey. Unclear whether the intervention focused on a single substance or many

\section{Risk of bias}

Bias

Media campaigns for the prevention of illicit drug use in young people (Review)

Copyright $\odot 2013$ The Cochrane Collaboration. Published by John Wiley \& Sons, Ltd. 
Fang 2010 (Continued)

\begin{tabular}{l|l|l}
$\begin{array}{l}\text { Random sequence generation (selection } \\
\text { bias) }\end{array}$ & Unclear risk & $\begin{array}{l}\text { p. } 530 \text { "Mother-daughter dyads were ran- } \\
\text { domly assigned to intervention }(\mathrm{n}=56) \text { and }\end{array}$ \\
& $\begin{array}{l}\text { control arms }(\mathrm{n}=52) \text { ", but randomisation } \\
\text { details are not reported }\end{array}$
\end{tabular}

Allocation concealment (selection bias) Low risk

Although full allocation concealment is not possible for this kind of study, there is low risk of selection bias because researchers administering the intervention were unlikely to know the children. See p. 530: "Delivered by voice-over narration, animated graphics, and games, session content involved skill demonstrations and interactive exercises that required the joint participation of mothers and daughters."

Blinding of outcome assessment (detection Low risk

Online questionnaire

bias)

p. 530 "Girls and mothers had separate and

All outcomes unique log-in names and passwords, and each completed a pretest and posttest survey online"

Incomplete outcome data (attrition bias) Low risk All outcomes
Low number of missing outcome data; missing data balanced in numbers across study groups

p. 530 "Mother-daughter dyads were randomly assigned to intervention $(\mathrm{n}=56)$ and control arms $(\mathrm{n}=52)$ "

"Two mother-daughter dyads attrited from each arm, and 104 dyads (54 intervention and 50 control) successfully completed both pretest and posttest measures"

p. 530 "The study protocol was approved by Columbia University's Institutional Review Board"

Fishbein 2002

Methods

Study design: randomised controlled trial

Sampling: systematic random sampling (letters from each included middle/high school) Comparison group(s): 5 experimental ( 6 advertisements each, embedded in a 24-minute documentary) + versus no intervention (documentary only) condition

Follow-up duration: not applicable

Study time span: not specified

Participants

3608 youths aged 11 to 18 years (grades 4 to 12 ), median age 15 years

Media campaigns for the prevention of illicit drug use in young people (Review) 
Fishbein 2002 (Continued)

Interventions

30 public service announcements produced by the Partnership for a Drug Free America (USA)

Outcomes

Notes
- 30 dependent variables (5 scores for each of the 6 PSAs)

- Perceived PSA effectiveness and realism

- Negative and positive emotional response

- Amount learned (understanding of intended message and on)

- 5 scores resulting from mean of the 6 PSA scores

- Total perceived PSA effectiveness and realism

- Total negative and positive emotional response

- Total amount learned (understanding of intended message and on)

- Perceptions:

- Perceived danger of engaging in risky behaviours

- Perceived harmfulness of engaging in risky behaviours

- Social norms

Risk of bias

\begin{tabular}{|c|c|c|}
\hline Bias & Authors' judgement & Support for judgement \\
\hline $\begin{array}{l}\text { Random sequence generation (selection } \\
\text { bias) }\end{array}$ & Unclear risk & $\begin{array}{l}\text { No mention of the sequence generation in } \\
\text { the article (methods section p. } 239 \text { ) }\end{array}$ \\
\hline Allocation concealment (selection bias) & Unclear risk & $\begin{array}{l}\text { No mention of the sequence generation in } \\
\text { the article (methods section p. 239) }\end{array}$ \\
\hline $\begin{array}{l}\text { Blinding of outcome assessment (detection } \\
\text { bias) } \\
\text { All outcomes }\end{array}$ & Low risk & $\begin{array}{l}\text { Anonymous questionnaire } \\
\text { p. } 240 \text { "Confidentiality and anonymity } \\
\text { were emphasized in the instructions, both } \\
\text { in written and audio-video form" }\end{array}$ \\
\hline $\begin{array}{l}\text { Incomplete outcome data (attrition bias) } \\
\text { All outcomes }\end{array}$ & Low risk & $\begin{array}{l}\text { Apparently almost all the sample exposed } \\
\text { to interventions were included in the final } \\
\text { analysis (and filled out the questionnaires) } \\
\text {. But no mention of the number originally } \\
\text { enrolled, mention of some drop-outs ap- } \\
\text { parently unlinked to outcomes but no ab- } \\
\text { solute numbers reported }\end{array}$ \\
\hline Selective reporting (reporting bias) & Low risk & $\begin{array}{l}\text { Protocol not available but we do not suspect } \\
\text { selective reporting }\end{array}$ \\
\hline
\end{tabular}




\begin{tabular}{|c|c|c|}
\hline Methods & \multicolumn{2}{|c|}{$\begin{array}{l}\text { Study design: before and after study } \\
\text { Sampling: 4-stage probability sampling } \\
\text { Comparison group(s): pre-intervention survey } \\
\text { Follow-up duration: n/a } \\
\text { Study time span: November } 2009 \text { to April } 2011 \text { (18 months) }\end{array}$} \\
\hline Participants & \multicolumn{2}{|c|}{4454 youths $(2432+2022)$} \\
\hline Interventions & \multicolumn{2}{|c|}{$\begin{array}{l}\text { Meth Project (USA), a "messaging campaign, supported by community outreach, and } \\
\text { public policy initiatives". The campaign comprises "television, radio, print, billboard, } \\
\text { and Internet advertising" }\end{array}$} \\
\hline Outcomes & \multicolumn{2}{|c|}{$\begin{array}{l}\text { - Past-month use of methamphetamine } \\
\text { - Attitudes towards methamphetamine and other drugs } \\
\text { - Perceptions concerning methamphetamine and other drugs } \\
\text { - Information sources and advertising awareness } \\
\text { - Statewide Meth Project awareness and perceptions }\end{array}$} \\
\hline \multicolumn{3}{|l|}{ Notes } \\
\hline \multicolumn{3}{|l|}{ Risk of bias } \\
\hline Bias & Authors' judgement & Support for judgement \\
\hline $\begin{array}{l}\text { Random sequence generation (selection } \\
\text { bias) }\end{array}$ & Unclear risk & Not applicable \\
\hline Allocation concealment (selection bias) & Unclear risk & Not applicable \\
\hline $\begin{array}{l}\text { Blinding of outcome assessment (detection } \\
\text { bias) } \\
\text { All outcomes }\end{array}$ & Low risk & Anonymous questionnaires \\
\hline $\begin{array}{l}\text { Incomplete outcome data (attrition bias) } \\
\text { All outcomes }\end{array}$ & Unclear risk & Not reported \\
\hline Selective reporting (reporting bias) & Unclear risk & $\begin{array}{l}\text { No information regarding potential report- } \\
\text { ing bias }\end{array}$ \\
\hline
\end{tabular}

Hawaii Meth 2011

Methods

Study design: interrupted time series study

Sampling: 4-stage probability sampling

Comparison group(s): pre-intervention survey

Follow-up duration: n/a

Study time span: March 2009 to March 2011 (25 months)

Participants

3305 youths $(1065+1035+1205)$

Media campaigns for the prevention of illicit drug use in young people (Review) 
Hawaii Meth 2011 (Continued)

\begin{tabular}{|c|c|c|}
\hline Interventions & \multicolumn{2}{|c|}{$\begin{array}{l}\text { Meth Project (USA), a "messaging campaign, supported by community outreach, and } \\
\text { public policy initiatives". The campaign comprises "television, radio, print, billboard, } \\
\text { and Internet advertising" }\end{array}$} \\
\hline Outcomes & \multicolumn{2}{|c|}{$\begin{array}{l}\text { - Past-month use of methamphetamine } \\
\text { - Attitudes on methamphetamine and other drugs } \\
\text { - Perceptions concerning methamphetamine and other drugs } \\
\text { - Information sources and advertising awareness } \\
\text { - Statewide Meth Project awareness and perceptions }\end{array}$} \\
\hline \multicolumn{3}{|l|}{ Notes } \\
\hline \multicolumn{3}{|l|}{ Risk of bias } \\
\hline Bias & Authors' judgement & Support for judgement \\
\hline $\begin{array}{l}\text { Random sequence generation (selection } \\
\text { bias) }\end{array}$ & Unclear risk & Not applicable \\
\hline Allocation concealment (selection bias) & Unclear risk & Not applicable \\
\hline $\begin{array}{l}\text { Blinding of outcome assessment (detection } \\
\text { bias) } \\
\text { All outcomes }\end{array}$ & Low risk & Anonymous questionnaires \\
\hline $\begin{array}{l}\text { Incomplete outcome data (attrition bias) } \\
\text { All outcomes }\end{array}$ & Unclear risk & Not reported \\
\hline Selective reporting (reporting bias) & Unclear risk & $\begin{array}{l}\text { No information regarding potential report- } \\
\text { ing bias }\end{array}$ \\
\hline
\end{tabular}

Hornik 2006

Methods

Study design: prospective cohort study

Sampling: systematic sampling (4-stage, geographic)

Comparison group(s): lower exposure to intervention

Follow-up duration: November 1999 to June 2004 (56 months)

Study time span: September 1999 to June 2004 (58 months). Up to 4 observations per each of the 3 cohorts. Interviews were carried out at home

Participants

Interventions
8117 youths aged 12.5 to 18 years in the first round

The National Youth Anti-Drug Media Campaign (USA) was a comprehensive social marketing campaign aimed at youths aged 9 to 18 years and disseminated though television, radio, websites, magazines, movie theatres and others. The campaign established partnership with civic, professional and community groups and outreach programs with the media, entertainment and sport industries 


\section{Hornik 2006 (Continued)}

\begin{tabular}{l|l}
\hline Outcomes & $\begin{array}{l}\text { - Lifetime, past-year and past 30-day use of marijuana } \\
\text { - Intention to use marijuana } \\
\text { - Attitudes towards marijuana and self efficacy to resist use of marijuana } \\
\text { - Perceptions and social norms about marijuana }\end{array}$ \\
\hline Notes & $\begin{array}{l}\text { NIDA report 'Evaluation of the National Youth Anti-Drug Media Campaign: } 2004 \\
\text { Report of Findings. June 2006', on which this article is based, was also used to retrieve } \\
\text { information for this meta-analysis }\end{array}$ \\
\hline
\end{tabular}

\section{Risk of bias}

\begin{tabular}{|c|c|c|}
\hline Bias & Authors' judgement & Support for judgement \\
\hline $\begin{array}{l}\text { Random sequence generation (selection } \\
\text { bias) }\end{array}$ & Unclear risk & Not applicable \\
\hline Allocation concealment (selection bias) & Unclear risk & Not applicable \\
\hline $\begin{array}{l}\text { Blinding of outcome assessment (detection } \\
\text { bias) } \\
\text { All outcomes }\end{array}$ & Low risk & $\begin{array}{l}\text { Anonymous and administered via com- } \\
\text { puter } \\
\text { p. } 2230 \text { (Hornik 2008) "NSPY ques- } \\
\text { tionnaires were administered on laptop } \\
\text { computers brought into the respondents' } \\
\text { homes. The interviewer recorded answers } \\
\text { for the opening sections, but for most of the } \\
\text { interview, to protect privacy, respondents } \\
\text { heard pre-recorded categories of questions } \\
\text { and answer through headphones and re- } \\
\text { sponded via touch screen selection on the } \\
\text { computer. Interviews could be conducted } \\
\text { in English or Spanish" }\end{array}$ \\
\hline $\begin{array}{l}\text { Incomplete outcome data (attrition bias) } \\
\text { All outcomes }\end{array}$ & Low risk & $\begin{array}{l}\text { "The overall response rate among youths } \\
\text { for the first round was } 65 \% \text {, with } 86 \% \\
\text { to } 93 \% \text { of still eligible youths interviewed } \\
\text { in subsequent rounds", page } 2230 \text { in Eval- } \\
\text { uation of the National Youth Anti-Drug } \\
\text { Media Campaign: } 2004 \text { Report of Find- } \\
\text { ings, page } 2-12 \text {, table } 2-A \text { "Completed in- } \\
\text { terviews by wave" }\end{array}$ \\
\hline Selective reporting (reporting bias) & Low risk & $\begin{array}{l}\text { No protocol available but the we do not } \\
\text { suspect selective reporting bias }\end{array}$ \\
\hline
\end{tabular}


Idaho Meth 2010

Methods

Study design: interrupted time series study

Sampling: 4-stage probability sampling

Comparison group(s): pre-intervention survey

Follow-up duration: n/a

Study time span: September 2007 to December 2010 (40 months)

Participants $\quad 11,143$ youths $(3091+2590+2641+2821)$

Interventions

Meth Project (USA), a "messaging campaign, supported by community outreach, and public policy initiatives". The campaign comprises "television, radio, print, billboard, and Internet advertising"

Outcomes

- Past-month use of methamphetamine

- Attitudes towards methamphetamine and other drugs

- Perceptions concerning methamphetamine and other drugs

- Informations sources and advertising awareness

- Statewide Meth Project awareness and perceptions

Notes

Risk of bias

\begin{tabular}{l|ll}
\hline Bias & Authors' judgement & Support for judgement \\
\hline $\begin{array}{l}\text { Random sequence generation (selection } \\
\text { bias) }\end{array}$ & Unclear risk & Not applicable \\
\hline $\begin{array}{l}\text { Allocation concealment (selection bias) } \\
\begin{array}{l}\text { Blinding of outcome assessment (detection } \\
\text { bias) } \\
\text { All outcomes }\end{array}\end{array}$ & Low risk & Not applicable \\
\hline $\begin{array}{l}\text { Incomplete outcome data (attrition bias) } \\
\text { All outcomes }\end{array}$ & Unclear risk & Anonymous questionnaires \\
\hline \begin{tabular}{l} 
Selective reporting (reporting bias) \\
\hline
\end{tabular} & Unclear risk & Not reported \\
\hline
\end{tabular}




\begin{tabular}{|c|c|}
\hline Methods & $\begin{array}{l}\text { Study design: randomised controlled trial. } \\
\text { Sampling: not specified. } \\
\text { Comparison group(s): } \\
\text { - control group (no anti-drug PSA and no group discussion). } \\
\text { - experimental group } 1 \text { (anti-drug PSA without group discussion) } \\
\text { - experimental group } 2 \text { (anti-drug PSA with group discussion) } \\
\text { Follow-up duration: } 1.5 \text { months (6 weeks). } \\
\text { Study time span: not specified, at least } 1.5 \text { months. }\end{array}$ \\
\hline Participants & 79 female college students, primarily 18 to 19 years old \\
\hline Interventions & $\begin{array}{l}\text { Anti-drug messages (USA) selected from the library of the Media Advertising Partnership } \\
\text { for a Drug-Free America and centred on drugs and alcohol }\end{array}$ \\
\hline Outcomes & $\begin{array}{l}\text { - Attitudes towards marijuana } \\
\text { - Attitudes towards cocaine } \\
\text { - Attitudes towards crack } \\
\text { - Attitude towards getting drunk }\end{array}$ \\
\hline Notes & $\begin{array}{l}\text { Pre-test, post-test and } 6 \text {-week follow-up means are provided. Standard deviations are not } \\
\text { provided }\end{array}$ \\
\hline
\end{tabular}

\section{Risk of bias}

\begin{tabular}{|c|c|c|}
\hline Bias & Authors' judgement & Support for judgement \\
\hline $\begin{array}{l}\text { Random sequence generation (selection } \\
\text { bias) }\end{array}$ & Unclear risk & $\begin{array}{l}\text { Not reported } \\
\text { p. } 80 \text { "Subjects were randomly divided into } \\
\text { a total of } 9 \text { discussion groups." }\end{array}$ \\
\hline Allocation concealment (selection bias) & Unclear risk & $\begin{array}{l}\text { Not reported } \\
\text { Baseline comparisons reported }\end{array}$ \\
\hline
\end{tabular}

Blinding of outcome assessment (detection Unclear risk

Blinding of outcome assessors not reported bias)

All outcomes

Incomplete outcome data (attrition bias) Low risk All outcomes

Selective reporting (reporting bias)
No missing data and clear reporting of sample size both of the intervention and control group

No study protocol available but clear reporting of main study hypothesis and direct correlation between main topics investigated in the experiment and reported outcomes

TOPICAL EXPERIMENTAL AREAS: p. 79 "two topical areas chosen for the study were (1) the age at which parents 
Kelly 1992 (Continued)

should talk to their children about dangers of drugs, (2) how much responsibility one has, if any, for another's drug use"

OUTCOMES:

p. 80 "three questions asking at what age children should be spoken to about marijuana, cocaine and crack"

p. 81 "one question asked subjects to rate their agreement on a 5 point Likert scale with the statement "whether or not I get drunk is nobody's business". Similar question were asked regarding use of marijuana, cocaine and crack"

Lee 2010

Methods

Study design: randomised controlled trial

Sampling: random sampling (letters and email sent to -4000 college students at a "large public university in the Northwest United States")

Comparison group(s): no intervention (no feedback or information, students were asked to complete web-based assessments)

Follow-up duration: 6 months

Study time span: June 2005 to not specified (at least 6 months because a 6-month followup was performed)

Participants

341 college students aged 17 to 19 with any use of marijuana in the 3 months before study

Interventions

Internet-based personalised feedback intervention (USA). Participants were presented with feedback about their marijuana use, perceived and actual descriptive norms about marijuana use, and perceived pros and cons of using marijuana. Skills and training tips for avoiding marijuana and making changes in use were provided, as well as limited alcohol feedback. Perceived high-risk contexts and alternative activities around campus and in the communities were provided

\begin{tabular}{|l|l}
\hline Outcomes & - Past 90 -day use of marijuana \\
- Contemplation to change marijuana use (intention) \\
- Consequences of marijuana use (knowledge) \\
- Family history of drug problem
\end{tabular}

Notes

Baseline survey, then 3- and 6-month follow-ups

Risk of bias

\begin{tabular}{|c|c|c|}
\hline Bias & Authors' judgement & Support for judgement \\
\hline $\begin{array}{l}\text { Random sequence generation (selection } \\
\text { bias) }\end{array}$ & Low risk & $\begin{array}{l}\text { Computer-based } \\
\text { p. } 267 \text {, "Students were randomly assigned }\end{array}$ \\
\hline
\end{tabular}

Media campaigns for the prevention of illicit drug use in young people (Review)

Copyright (c) 2013 The Cochrane Collaboration. Published by John Wiley \& Sons, Ltd. 
Lee 2010 (Continued)

\begin{tabular}{|c|c|c|}
\hline & & $\begin{array}{l}\text { to a personalized feedback intervention } \\
\text { (PFI) or control condition based on their } \\
\text { screening responses (prior to baseline), us- } \\
\text { ing a stratified randomization procedure to } \\
\text { produce groups with equivalent use rates at } \\
\text { randomization" }\end{array}$ \\
\hline Allocation concealment (selection bias) & Low risk & $\begin{array}{l}\text { Although full allocation concealment is not } \\
\text { possible for this kind of study, there is low } \\
\text { risk of selection bias because researchers ad- } \\
\text { ministering the intervention were unlikely } \\
\text { to know the children. See p. 268: "Students } \\
\text { in the intervention group received individ- } \\
\text { ual personalized feedback based on base- } \\
\text { line information. On completion of the } \\
\text { baseline survey, PFI participants could im- } \\
\text { mediately view feedback online and could } \\
\text { choose to print feedback to their own } \\
\text { printer. Participants could return to view } \\
\text { feedback on the web for } 3 \text { months" }\end{array}$ \\
\hline $\begin{array}{l}\text { Blinding of outcome assessment (detection } \\
\text { bias) } \\
\text { All outcomes }\end{array}$ & Low risk & $\begin{array}{l}\text { Computer-administered questionnaire (p. } \\
266-7 \text { ) }\end{array}$ \\
\hline $\begin{array}{l}\text { Incomplete outcome data (attrition bias) } \\
\text { All outcomes }\end{array}$ & Low risk & $\begin{array}{l}\text { p. } 268 \text { "All analyses are based on intent- } \\
\text { to-treat, regardless of whether participants } \\
\text { viewed their feedback" }\end{array}$ \\
\hline Selective reporting (reporting bias) & Unclear risk & $\begin{array}{l}\text { p. } 267 \text { "All study procedures were approved } \\
\text { by the university IRB and a federal Certifi- } \\
\text { cate of Confidentiality was obtained from } \\
\text { the National Institutes of Health" }\end{array}$ \\
\hline
\end{tabular}

Miller 2000

Methods

Study design: before and after study

Sampling: random sampling

Comparison group $(s)$ : no intervention (other campus with no intervention)

Follow-up duration: 1 year

Study time span: $1988-9$, for 1.5 years

Participants

1024 college students at baseline (median age 25 in the intervention group, 22 in the control group), 865 at 1-year follow-up

Interventions

The Campuswide Alcohol and Drug Abuse Prevention Program (CADAPP; USA), based on self regulation theory. The campaign made use of printed materials, videotapes, speakers, peer-education, computer resources, campus policy, campus wide events. Other components of CADAPP targeted particular at-risk segments: free and confiden-

Media campaigns for the prevention of illicit drug use in young people (Review)

Copyright (c) 2013 The Cochrane Collaboration. Published by John Wiley \& Sons, Ltd. 
Miller 2000 (Continued)

tial psychological 'drinker's checkup', list of drug/alcohol referral services available in the community, free psychological help for concerned family members and friends, alcohol self control training for on-campus fraternities

$\begin{array}{ll}\text { Outcomes } & \text { - Frequency of use of } 10 \text { types of drugs including cannabis and cocaine } \\ & \text { - Past 30-day alcohol consumption } \\ & \text { - Perception of risk related to alcohol and other drugs use } \\ & \text { - Problems related to alcohol and other drug use }\end{array}$

\section{Risk of bias}

\begin{tabular}{|c|c|c|}
\hline Bias & Authors' judgement & Support for judgement \\
\hline $\begin{array}{l}\text { Random sequence generation (selection } \\
\text { bias) }\end{array}$ & Unclear risk & Not applicable \\
\hline Allocation concealment (selection bias) & Unclear risk & Not applicable \\
\hline $\begin{array}{l}\text { Blinding of outcome assessment (detection } \\
\text { bias) } \\
\text { All outcomes }\end{array}$ & Low risk & $\begin{array}{l}\text { Anonymous questionnaire } \\
\text { p. } 746 \text { "Impact of CADAPP was measured } \\
\text { through anonymous surveys of students on } \\
\text { each campus [..]" }\end{array}$ \\
\hline $\begin{array}{l}\text { Incomplete outcome data (attrition bias) } \\
\text { All outcomes }\end{array}$ & Low risk & $\begin{array}{l}\text { p. } 751 \text { "At baseline (fall) assessment, } 1 \text {, } \\
400 \text { surveys were distributed to enrolled } \\
\text { UNM students, a sample of approximately } \\
6 \% \text { selected randomly by the university's } \\
\text { computerized mailing list program. Of } \\
\text { these, } 567 \text { surveys were returned and usable } \\
(41 \%) \text {. At the control campus, } 1,080 \text { sur- } \\
\text { veys were distributed to a random sample of } \\
\text { students, } 457 \text { of whom returned them ( } 42 \text {. } \\
3 \%) \text {. [..] The return rates were } 431(31 \%) \\
\text { at UNM and } 434(34 \%) \text { at NMSU" }\end{array}$ \\
\hline Selective reporting (reporting bias) & Unclear risk & $\begin{array}{l}\text { No information regarding potential report- } \\
\text { ing bias }\end{array}$ \\
\hline
\end{tabular}



tion branch: $\mathrm{N}=397,5$ schools; control branch: $\mathrm{N}=367,5$ schools). Students who enrol in independent schools come predominantly from high socioeconomic backgrounds

Interventions

Climate Schools course (Australia) is an Internet-based intervention founded on the social influence approach, derived from Bandura's social learning theory. The course delivered 2 sets of 6 40-minute lessons, each including 15 to 20-minute Internet-based lesson completed individually and 20 to 25 -minute teacher-delivered activities. During the Internet-based part, students followed a cartoon storyline of teenagers experiencing real-life situations and problems with alcohol and cannabis

$\begin{array}{ll}\text { Outcomes } & \text { - Use of alcohol (number of drinks per week) and cannabis (times per week) } \\ \text { - Alcohol and cannabis knowledge } \\ \text { - Alcohol and cannabis attitudes } \\ \text { - Alcohol- and cannabis-related harms }\end{array}$

Hybrid intervention: both school- and Internet-based

\section{Risk of bias}

Bias Authors' judgement

Random sequence generation (selection Low risk bias)

\section{Support for judgement}

p. 750 "The 10 participating schools were assigned randomly using an online randomization system (www.randomizer.org) to either the control condition (usual drug education) or the intervention condition (the Climate Schools: Alcohol and Cannabis course)"

Allocation concealment (selection bias) Low risk
Although full allocation concealment is not possible for this kind of study, there is low risk of selection bias because researchers administering the intervention were unlikely to know the children. See p. 750 "The Climate Schools: Alcohol and Cannabis course comprised the delivery of two sets of six 40-minute lessons. The Climate Schools: Alcohol module was delivered immediately after the baseline assessment, and the Climate Schools: Alco- 
Newton 2010 (Continued)

hol and Cannabis module was delivered 6 months later in the same school year. Each lesson included a 15-20-minute Internetbased lesson completed individually, where students followed a cartoon storyline of teenagers experiencing real-life situations and problems with alcohol and cannabis. The second part of each lesson was a predetermined activity delivered by the teacher to reinforce the information taught in the cartoons. Intervention group teachers were provided with a programme manual but no additional training."

Blinding of outcome assessment (detection Low risk bias)

All outcomes

Incomplete outcome data (attrition bias) Low risk All outcomes p. 751 "A self-report questionnaire was completed online by all students in a classroom setting, where anonymity and confidentiality were assured"

Similar attrition \% over the 2 study groups (figure 1, page 754)

p. 754 "Compared to students who were present at baseline and any follow-up occasion, students present only at baseline had significantly higher alcohol-related knowledge [7.66 versus 7.48 (of 16); $\mathrm{F}(1,758$ ) $=4.88, \mathrm{P}<0.05]$. There were no significant differences on any other alcohol or cannabis outcome measures, nor was there evidence of differential attrition"

No study protocol was mentioned

\section{Palmgreen 1991}

Methods
Study design: randomised controlled trial.

Sampling: random sampling (students were recruited from a variety of sources, including driver's licence listings, recruitment advertisements in local newspapers and shopper weekly, etc)

Comparison group(s): 2 experimental viewing conditions

- one public service announcements (PSA) aimed at high sensation-seekers (HSSs)

- one PSA aimed at low sensation-seekers (LSSs)

Follow-up duration: not applicable

Study time span: not specified, at least 1 day 
Palmgreen 1991 (Continued)

\begin{tabular}{l|l}
$\begin{array}{l}\text { Interventions } \\
\text { (USA) }\end{array}$ & $\begin{array}{l}\text { national-quality 30-second embedded PSAs, one aimed at HSS and the other at LSS } \\
\text { Outcomes }\end{array}$ \\
\hline Notes & \begin{tabular}{l} 
Intention to call a support hotline \\
\hline
\end{tabular} \\
\hline
\end{tabular}

\section{Risk of bias}

\begin{tabular}{|c|c|c|}
\hline Bias & Authors' judgement & Support for judgement \\
\hline $\begin{array}{l}\text { Random sequence generation (selection } \\
\text { bias) }\end{array}$ & Unclear risk & $\begin{array}{l}\text { Not clearly reported } \\
\text { p. } 221 \text { "LSSs ad HSSs were randomly as- } \\
\text { signed to one of the experimental condi- } \\
\text { tions or the control group" }\end{array}$ \\
\hline Allocation concealment (selection bias) & Unclear risk & $\begin{array}{l}\text { Not reported } \\
\text { No baseline comparisons reported }\end{array}$ \\
\hline $\begin{array}{l}\text { Blinding of outcome assessment (detection } \\
\text { bias) } \\
\text { All outcomes }\end{array}$ & Unclear risk & Blinding of outcome assessors not reported \\
\hline $\begin{array}{l}\text { Incomplete outcome data (attrition bias) } \\
\text { All outcomes }\end{array}$ & Low risk & $\begin{array}{l}\text { No missing data and clear reporting of sam- } \\
\text { ple size both of the intervention and con- } \\
\text { trol group }\end{array}$ \\
\hline Selective reporting (reporting bias) & Low risk & $\begin{array}{l}\text { No study protocol available but clear re- } \\
\text { porting of main study hypothesis (p. 219) } \\
\text { and outcomes measures }\end{array}$ \\
\hline
\end{tabular}

Palmgreen 2001

\begin{tabular}{ll} 
Methods & $\begin{array}{l}\text { Study design: interrupted time series study } \\
\text { Sampling: systematic sampling (geographical and grade stratification from enrolment } \\
\text { lists of 7th to 10th graders in spring 1996) } \\
\text { Comparison group(s): pre-intervention surveys } \\
\text { Follow-up duration: n/a } \\
\text { Study time span: March } 1996 \text { to December } 1998 \text { (34 months) }\end{array}$ \\
\hline Participants & $\begin{array}{l}6371 \text { youths from 7th to 10th grade (12- to 17-year-olds), 3174 from Fayette County } \\
\text { and } 3197 \text { youths from Knox County }\end{array}$ \\
\hline Interventions & $\begin{array}{l}3 \text { anti-marijuana public service announcements televised from January through April } \\
1997 \text { and from January through April } 1998 \text { in Fayette and Knox Counties (USA). These } \\
\text { advertisements were based on the SENTAR (sensation-seeking targeting) prevention } \\
\text { approach }\end{array}$
\end{tabular}


Palmgreen 2001 (Continued)

\begin{tabular}{|c|c|c|}
\hline Outcomes & \multicolumn{2}{|c|}{ - Past 30-day use of marijuana } \\
\hline Notes & \multicolumn{2}{|c|}{$\begin{array}{l}\text { The } 2 \text { samples differed significantly on some independent (e.g. perceived peer and fam- } \\
\text { ily drug use, delinquency) and dependent (use of marijuana) variables, although demo- } \\
\text { graphic and sensation-seeking variables were consistent between the } 2 \text { samples }\end{array}$} \\
\hline \multicolumn{3}{|l|}{ Risk of bias } \\
\hline Bias & Authors' judgement & Support for judgement \\
\hline $\begin{array}{l}\text { Random sequence generation (selection } \\
\text { bias) }\end{array}$ & Unclear risk & Not applicable \\
\hline Allocation concealment (selection bias) & Unclear risk & Not applicable \\
\hline $\begin{array}{l}\text { Blinding of outcome assessment (detection } \\
\text { bias) } \\
\text { All outcomes }\end{array}$ & Low risk & $\begin{array}{l}\text { Anonymous questionnaire } \\
\text { p. } 293 \text { "Interviews were private and anony- } \\
\text { mous, with self-administration of drug and } \\
\text { alcohol items via laptop computer" }\end{array}$ \\
\hline $\begin{array}{l}\text { Incomplete outcome data (attrition bias) } \\
\text { All outcomes }\end{array}$ & Unclear risk & Not reported \\
\hline Selective reporting (reporting bias) & Unclear risk & $\begin{array}{l}\text { No information regarding potential report- } \\
\text { ing bias }\end{array}$ \\
\hline
\end{tabular}

Polansky 1999

\begin{tabular}{l|l}
\hline Methods & $\begin{array}{l}\text { Study design: randomised controlled trial } \\
\text { Sampling: systematic sampling (gender, classroom) } \\
\text { Comparison group }(s): 2 \times 2 \times 4 \text { design (replication } \times \text { gender } \times \text { treatment) } \\
\begin{array}{l}\text { Follow-up duration: not specified } \\
\text { Study time span: not specified }\end{array}\end{array}$ \\
\hline Participants & $\begin{array}{l}312 \text { 7th through to 9th graders from a rural south-western Mexican-American commu- } \\
\text { nity }\end{array}$ \\
\hline Interventions & $\begin{array}{l}3 \text { substance abuse prevention videotapes (USA) derived from different theoretical frame- } \\
\text { works: information-based programming, social skills approach and assertiveness training } \\
\text { (a subset of social skills approach) }\end{array}$ \\
\hline Outcomes & $\begin{array}{l}\text { - Attitudes towards drugs } \\
\text { - Use of drugs } \\
\text { - Other: knowledge of videotape content and disposition to select socially } \\
\text { appropriate responses }\end{array}$ \\
\hline
\end{tabular}


Polansky 1999 (Continued)

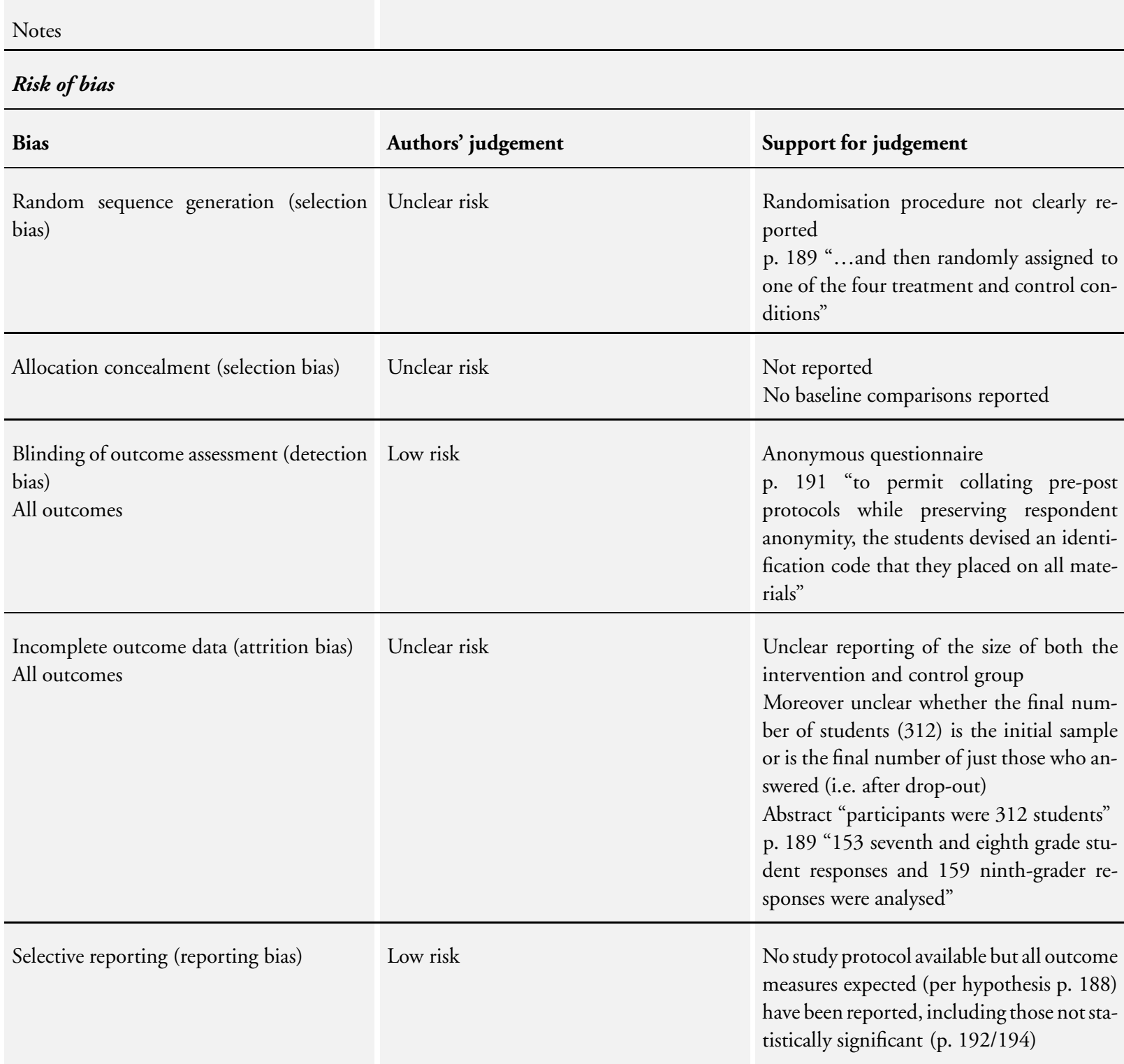

Scheier 2010

\begin{tabular}{ll} 
Methods & $\begin{array}{l}\text { Study design: prospective cohort study } \\
\text { Sampling: systematic sampling (representative of major racial groups) } \\
\text { Comparison group(s): lower exposure to intervention }\end{array}$ \\
$\begin{array}{l}\text { Follow-up duration: } 48 \text { months } \\
\text { Study time span: April } 1999 \text { to March } 2003 \text { (48 months) }\end{array}$ \\
\hline Participants & $\begin{array}{l}2515 \text { youth aged } 12 \text { to } 18 \text { interviewed by the National Survey of Parents and Youth } \\
\text { (NSPY) }\end{array}$
\end{tabular}

Media campaigns for the prevention of illicit drug use in young people (Review) 
Scheier 2010 (Continued)

\begin{tabular}{|c|c|c|}
\hline Interventions & \multicolumn{2}{|c|}{$\begin{array}{l}\text { The National Youth Anti-Drug Media Campaign (USA), already described in Hornik } \\
2006\end{array}$} \\
\hline Outcomes & \multicolumn{2}{|c|}{$\begin{array}{l}\text { - Past } 12 \text {-month episodes of drunkenness or cannabis intoxication } \\
\text { - Past } 30 \text {-day binge drinking ( } 5 \text { or more drinks in a row) } \\
\text { - Past } 30 \text {-day use of cigarettes }\end{array}$} \\
\hline \multicolumn{3}{|l|}{ Notes } \\
\hline \multicolumn{3}{|l|}{ Risk of bias } \\
\hline Bias & Authors' judgement & Support for judgement \\
\hline $\begin{array}{l}\text { Random sequence generation (selection } \\
\text { bias) }\end{array}$ & Unclear risk & Not applicable \\
\hline Allocation concealment (selection bias) & Unclear risk & Not applicable \\
\hline $\begin{array}{l}\text { Blinding of outcome assessment (detection } \\
\text { bias) } \\
\text { All outcomes }\end{array}$ & Low risk & $\begin{array}{l}\text { Anonymous and computer-administered } \\
\text { questionnaire } \\
\text { p. } 248 \text { "Assessment of alcohol and drug } \\
\text { use relied on an Anonymous Computer As- } \\
\text { sisted Self-report Interview (ACASI)" }\end{array}$ \\
\hline $\begin{array}{l}\text { Incomplete outcome data (attrition bias) } \\
\text { All outcomes }\end{array}$ & Low risk & $\begin{array}{l}\text { Same as Hornik } 2008 \text { ("The overall re- } \\
\text { sponse rate among youths for the first } \\
\text { round was } 65 \% \text {, with } 86 \% \text { to } 93 \% \text { of still } \\
\text { eligible youths interviewed in subsequent } \\
\text { rounds", page } 2230 \text { Evaluation of the Na- } \\
\text { tional Youth Anti-Drug Media Campaign: } \\
2004 \text { Report of Findings, page 2-12, table } \\
2 \text {-A "Completed interviews by wave") }\end{array}$ \\
\hline Selective reporting (reporting bias) & Unclear risk & Not applicable \\
\hline
\end{tabular}

Schwinn 2010

\begin{tabular}{|c|c|}
\hline Methods & $\begin{array}{l}\text { Study design: randomised controlled trial } \\
\text { Sampling: random sampling } \\
\text { Comparison group(s): no intervention } \\
\text { Follow-up duration: } 6 \text { months } \\
\text { Study time span: at least } 8 \text { months (not directly specified, but pretest was administered } \\
6 \text { weeks before intervention and last follow-up was assessed after } 6 \text { months) }\end{array}$ \\
\hline Participants & $\begin{array}{l}236 \text { girls aged } 13 \text { to } 14 \text { from } 42 \text { US states and } 4 \text { Canadian provinces, recruited through } \\
\text { the youth-oriented website Kiwibox.com }\end{array}$ \\
\hline
\end{tabular}


Schwinn 2010 (Continued)

$\begin{array}{ll}\text { Interventions } & \text { Internet-based gender-specific intervention (USA, Canada) composed by } 12 \text { sessions. } \\ \text { This intervention is a pilot test of a gender-specific intervention based on the social learn- } \\ \text { ing theory and employs a social competence and skill building strategy. High interaction }\end{array}$

Outcomes - Past 30-day alcohol, cigarette, marijuana, poly drug and total substance use

- Mediator variables

- Decision-making skills

- Goal-setting skills

- Drug resistance/refusal skills

- Stress management

- Social skills

- Self esteem

- Body esteem

- Self efficacy

Notes

Baseline and 6-month follow-up

Risk of bias

Bias

Random sequence generation (selection Unclear risk bias)

Allocation concealment (selection bias)

Low risk

\section{Support for judgement}

p. 26 "After study enrolment, girls were randomly assigned to the intervention or control arm"

Although full allocation concealment is not possible for this kind of study, there is low risk of selection bias because researchers administering the intervention were unlikely to know the children. See p. 26 "After completing online pretest measures, intervention girls were immediately directed to the first program session. Control girls were thanked for their time and reminded that they would be notified when the next survey was available."

Blinding of outcome assessment (detection Low risk bias)

All outcomes

Incomplete outcome data (attrition bias) Low risk All outcomes
Computer-administered questionnaire p. 26 "After completing online pretest measures, intervention girls were immediately directed to the first program session. [..] Immediately following completion of the last program module, girls in the intervention group completed the post-test"

p. 28 "Differential attrition was assessed across the three measurement occasions using the same variables analysed in baseline

Media campaigns for the prevention of illicit drug use in young people (Review) 
Schwinn 2010 (Continued)

\begin{tabular}{|c|c|c|}
\hline & & $\begin{array}{l}\text { equivalency. Pretest to posttest attrition was } \\
6.8 \% \text {; the attrition rates for girls in inter- } \\
\text { vention and control groups did not differ, } \\
\mathrm{X} 2(1)=1.74, \mathrm{p}>0.05 \text {. At final follow-up, } \\
\text { attrition was } 9 \% \text {; again, rates did not differ } \\
\text { by study group, X2 }(1)=0.84, \mathrm{p}>0.05 \%\end{array}$ \\
\hline Selective reporting (reporting bias) & High risk & $\begin{array}{l}\text { Protocol not mentioned. Subjective out- } \\
\text { comes were not described in full but only } \\
\text { as predictors of objective outcomes (sub- } \\
\text { stance use) }\end{array}$ \\
\hline
\end{tabular}

Slater 2006

Methods

Study design: quasi-randomised controlled trial (assignment to media condition was random; assignment to school condition was not fully random because of problem of staff scheduling in 7 of the 16 communities)

Sampling: randomised cluster sampling (treatment and control communities were extracted from 4 major regions of the US)

Comparison group(s): no intervention (8 intervention versus 8 non-intervention communities)

Follow-up duration: 24 months

Study time span: Autumn 1999 to Spring 2003 ( -42 months; but intervention lasted 24 months for each community, entry to the in project was different in different communities)

4216 6th- and 7th-grade students; mean age at baseline was 12.2 years

Interventions

The 'Be Under Your Own Influence' programme (USA) is a school- and communitybased media effort on marijuana, alcohol and tobacco uptake. The programme emphasised "non-use as an expression of personal identity and the consistency of non-use with youth aspiration". The school-based intervention was research-based All Stars ${ }^{\mathrm{TM}}$ (13 sessions in the first year +7 booster sessions in the second year); the community intervention was composed of workshops held by trained project staff

Outcomes

- Lifetime and past 30-day use of marijuana

- Lifetime and past 30-day episodes of alcohol intoxication

- Lifetime and current smoking of cigarettes

Notes

This intervention ran concurrently with the Office of National Drug Policy's national anti-drug campaign (Hornik 2006; Scheier 2010), but their simultaneous effect was not assessed in this study

Risk of bias

Bias

Authors' judgement

Support for judgement

Media campaigns for the prevention of illicit drug use in young people (Review)

Copyright @ 2013 The Cochrane Collaboration. Published by John Wiley \& Sons, Ltd. 


\section{Slater 2006 (Continued)}

\author{
Random sequence generation (selection Unclear risk \\ bias)
}

Allocation concealment (selection bias) Low risk

Blinding of outcome assessment (detection Unclear risk bias)

All outcomes

Incomplete outcome data (attrition bias) Low risk

All outcomes

Selective reporting (reporting bias) Low risk

Matching procedure described but no specification of random sequence generation

Although full allocation concealment is not possible for this kind of study, there is low risk of selection bias because researchers administering the intervention were unlikely to know the children

Blinding of outcome assessors not reported Missing data have been imputed using appropriate methods (p. 161)

No protocol available but the we do not suspect selective reporting bias

Slater 2011

Methods

Study design: randomised controlled trial with a nested prospective cohort study Sampling: systematic sampling (schools were recruited based on National Center for Educational Statistics district listings)

Comparison group(s): 4 groups, each including 10 schools and each comprising low to high exposure to the ONDCP campaign

- Be Under Your Own Influence (BUYOI) intervention both at school and in the community

- BUYOI intervention at school but not in the community

- BUYOI intervention in the community but not at school

- no BUYOI intervention neither at school nor in the community

Follow-up duration: 24 months

Study time span: Autumn 2005 to Spring 2009 ( -42 months)

Participants

Interventions
3236 students, mean age $12.4 \pm 0.6$ years

The Office of National Drug Control Policy's (ONDCP) 'Above the Influence' media campaign (USA) and a school- and community-based mass media intervention, 'Be Under Your Own Influence' (BUYOI; USA). They both started in 2005 and ran concurrently

- The ONDCP's campaign is the rebranded version of the national anti-drug campaign launched in 1998 (Hornik 2006; Palmgreen 2007; Scheier 2010). This version, like the original one, used televised ads supplemented by printed ads (e.g. posters)

- The BUYOI campaign is a replication and extension of a campaign launched in 1999 (Slater 2006). This campaign employed only printed ads and was implemented both in schools and communities

Although the ONDCP's campaign used far more creative executions given its funding 
Slater 2011 (Continued)

levels, both campaigns were similar in concept, i.e. both linked substance use with autonomy and aspiration threats

Outcomes

- Attitudes: autonomy and aspiration inconsistent with marijuana use

- Lifetime, past 90-day and past 30-day use of marijuana

Notes

Risk of bias

\begin{tabular}{|c|c|c|}
\hline Bias & Authors' judgement & Support for judgement \\
\hline $\begin{array}{l}\text { Random sequence generation (selection } \\
\text { bias) }\end{array}$ & Low risk & $\begin{array}{l}\text { Page } 15 \text { "Random assignment used a } \\
\text { group-matching procedure: NCES data } \\
\text { on community demographics and location } \\
\text { were used to generate possible randomiza- } \\
\text { tion schemes in which major demograph- } \\
\text { ics and location were balanced to the de- } \\
\text { gree possible across experimental condi- } \\
\text { tions and one of the acceptable schemes was } \\
\text { randomly selected." }\end{array}$ \\
\hline
\end{tabular}

Allocation concealment (selection bias) Low risk

Although full allocation concealment is not possible for this kind of study, there is low risk of selection bias because researchers administering the intervention were unlikely to know the children

Blinding of outcome assessment (detection Unclear risk

It is unclear who administered the quesbias) tionnaires and whether they were anonymous

All outcomes

Reasons for missing outcome data unlikely

Incomplete outcome data (attrition bias) Low risk

All outcomes

to be related to true outcome

Selective reporting (reporting bias) Low risk

No protocol available but the we do not suspect selective reporting

\section{Wyoming Meth 2011}

Methods

Study design: interrupted time series study

Sampling: 4-stage probability sampling

Comparison group(s): pre-intervention survey

Follow-up duration: n/a

Study time span: April 2008 to May 2011 (34 months)

Participants

5700 youths $(909+913+2652+1226)$

Media campaigns for the prevention of illicit drug use in young people (Review) 


\section{Wyoming Meth 2011 (Continued)}

Interventions
$\begin{aligned} & \text { Meth Project (USA), a "messaging campaign, supported by community outreach, and } \\ & \text { public policy initiatives". The campaign comprises "television, radio, print, billboard, } \\ & \text { and Internet advertising" }\end{aligned}$

\begin{tabular}{ll} 
Outcomes & - Past-month use of methamphetamine \\
& - Attitudes towards methamphetamine and other drugs \\
& - Perceptions concerning methamphetamine and other drugs \\
& - Informations sources and advertising awareness \\
& - Statewide Meth Project awareness and perceptions \\
\hline Notes & \\
\hline
\end{tabular}

\section{Risk of bias}

\begin{tabular}{|c|c|c|}
\hline Bias & Authors' judgement & Support for judgement \\
\hline $\begin{array}{l}\text { Random sequence generation (selection } \\
\text { bias) }\end{array}$ & Unclear risk & Not applicable \\
\hline Allocation concealment (selection bias) & Unclear risk & Not applicable \\
\hline $\begin{array}{l}\text { Blinding of outcome assessment (detection } \\
\text { bias) } \\
\text { All outcomes }\end{array}$ & Low risk & Anonymous questionnaires \\
\hline $\begin{array}{l}\text { Incomplete outcome data (attrition bias) } \\
\text { All outcomes }\end{array}$ & Unclear risk & Not reported \\
\hline Selective reporting (reporting bias) & Unclear risk & $\begin{array}{l}\text { No information regarding potential report- } \\
\text { ing bias }\end{array}$ \\
\hline
\end{tabular}

Yzer 2003

Methods

Study design: randomised controlled trial

Sampling: random sampling (from middle and high schools)

Comparison group(s):

- no intervention (documentary with no advertisements)

- gateway condition (explicit: 4 anti-hard drug followed by a teenage girl's testimonial about how her trial use of marijuana led to using hard drugs)

- implicit gateway condition (2 anti-marijuana and 2 anti-hard drugs advertisements without explicit reference to the gateway concept)

- hard drugs condition (same advertisements of gateway condition, but not followed by testimonials)

Follow-up duration: not applicable (post-only design)

Study time span: March 2000 to not specified 
Yzer 2003 (Continued)

\begin{tabular}{l|l} 
Interventions & $\begin{array}{l}\text { Anti-marijuana and anti-hard drugs advertisements embedded in a documentary video } \\
\text { (USA) }\end{array}$ \\
\hline Outcomes & $\begin{array}{l}\text { - Intention to use marijuana in the next } 12 \text { months } \\
\text { - Attitude towards marijuana } \\
\text { - Perceptions about marijuana }\end{array}$ \\
\hline Notes & Similar to Zhao 2006, many of the authors wrote both papers \\
\hline
\end{tabular}

\section{Risk of bias}

\begin{tabular}{|c|c|c|}
\hline Bias & Authors' judgement & Support for judgement \\
\hline $\begin{array}{l}\text { Random sequence generation (selection } \\
\text { bias) }\end{array}$ & Low risk & $\begin{array}{l}\text { Participants were randomly assigned to } 1 \\
\text { of the } 4 \text { experimental conditions, and the } \\
\text { stimuli were randomly presented using a } \\
\text { randomisation feature in MediaLab soft- } \\
\text { ware. (Personal communication with the } \\
\text { author) }\end{array}$ \\
\hline Allocation concealment (selection bias) & Low risk & $\begin{array}{l}\text { Participants did not know which condition } \\
\text { they were assigned to, and thus did not } \\
\text { know which stimuli they and participants } \\
\text { in other conditions were exposed to. (Per- } \\
\text { sonal communication with the author) }\end{array}$ \\
\hline $\begin{array}{l}\text { Blinding of outcome assessment (detection } \\
\text { bias) } \\
\text { All outcomes }\end{array}$ & Low risk & $\begin{array}{l}\text { Anonymous questionnaire } \\
\text { p. } 135 \text { "All videos and the questionnaire } \\
\text { were programmed onto a laptop computer } \\
\text { using an interactive program that allows } \\
\text { random ordering of questions and videos } \\
\text { within blocks" }\end{array}$ \\
\hline $\begin{array}{l}\text { Incomplete outcome data (attrition bias) } \\
\text { All outcomes }\end{array}$ & Low risk & $\begin{array}{l}\text { There were no missing data. (Personal com- } \\
\text { munication with the author) }\end{array}$ \\
\hline Selective reporting (reporting bias) & Low risk & $\begin{array}{l}\text { No protocol available but the we do not } \\
\text { suspect selective reporting bias }\end{array}$ \\
\hline
\end{tabular}


Study time span: not specified

\section{Participants}

Interventions

Notes

\section{Risk of bias}

435 youths whose mean age was $15.2 \pm 1.88$ years

3 anti-marijuana advertisements (USA) addressing normative beliefs. The advertisements were embedded and randomly included in a video documentary about television production

- Behavioural beliefs towards marijuana (perceptions)

- Intention to use marijuana

- Social norms on marijuana (perceptions)

Results were based on combined data from 3 studies done at different points in time, but "identical in terms of methodology, procedures, experimental conditions, ad the structure of the outcome questionnaire". However, whereas study 1 and 2 were collected at middle and high schools, study 3 was conducted at various malls around the country

\section{Bias}

Random sequence generation (selection Unclear risk bias)

Allocation concealment (selection bias)
Low risk

\section{Support for judgement}

p. 190 "Participants were randomly assigned to condition", but randomisation details are not reported

Although full allocation concealment is not possible for this kind of study, there is low risk of selection bias because researchers administering the intervention were unlikely to know the children. See p. 190: "The experimental group saw the three advertisements that challenged undesirable normative beliefs about marijuana use (see Table 1 for a description of the messages). The advertisements were embedded and randomly rotated in a video documentary about television production. The control group was not exposed to any anti-marijuana messages but saw the same documentary as the experimental group" 


\begin{tabular}{|c|c|c|}
\hline $\begin{array}{l}\text { Blinding of outcome assessment (detection } \\
\text { bias) } \\
\text { All outcomes }\end{array}$ & Low risk & $\begin{array}{l}\text { Computer-administered questionnaire } \\
\text { p. } 191 \text { "The instrument (including the } \\
\text { video clips) was programmed onto laptop } \\
\text { computers using an interactive program } \\
\text { called MediaLab (Jarvis, 1998), which al- } \\
\text { lows random ordering of blocks of ques- } \\
\text { tions and videos within the questionnaire" }\end{array}$ \\
\hline $\begin{array}{l}\text { Incomplete outcome data (attrition bias) } \\
\text { All outcomes }\end{array}$ & Low risk & $\begin{array}{l}\text { All participants completed the test (being } \\
\text { a post-only design); p. } 190 \text { "All three stud- } \\
\text { ies used the same between-subjects, post- } \\
\text { only design, with one experimental condi- } \\
\text { tion and one control condition" }\end{array}$ \\
\hline Selective reporting (reporting bias) & Unclear risk & No study protocol was mentioned \\
\hline
\end{tabular}

n/a: not applicable

PSA: public service announcement

\section{Characteristics of excluded studies [ordered by study ID]}

\begin{tabular}{|c|c|}
\hline Study & Reason for exclusion \\
\hline Alemi 1996 & Target population is pregnant women who already use or used cocaine \\
\hline An 2007 & $\begin{array}{l}\text { This intervention aims to promote inquiry of prescription medicines/treatments, not to hinder use of illicit } \\
\text { drugs }\end{array}$ \\
\hline Andrews 1995 & $\begin{array}{l}\text { The purpose of the campaign was to promote public awareness of the link between addiction and child } \\
\text { maltreatment, not to prevent addiction }\end{array}$ \\
\hline Barber 1990 & Target population mean age is 40 \\
\hline Beaudoin 2007 & Presented outcomes are not included among those of this review \\
\hline Beck 2008 & $\begin{array}{l}\text { Overview of drugs prevalence and school-based prevention interventions in France. Some information about } \\
\text { therapeutic interventions, but no information about mass media prevention interventions }\end{array}$ \\
\hline Belenko 2009 & $\begin{array}{l}\text { This study analyses data from the National Survey of Parents and Youth, which was not designed to provide } \\
\text { quality information about exposure to anti- or pro-drug websites. This study aims to find factors (e.g. gender, } \\
\text { parent-reported income, prior exposure to drugs) associated with viewing of drug websites, not to assess } \\
\text { whether viewing of anti-drug websites can influence outcomes included in the protocol of this review }\end{array}$ \\
\hline
\end{tabular}

Media campaigns for the prevention of illicit drug use in young people (Review) 
(Continued)

\begin{tabular}{|c|c|}
\hline Black 1994 & This study aims to assess consistency of data collected with 2 different sampling methods \\
\hline Brannon 1989 & $\begin{array}{l}\text { None of the evaluated outcomes (i.e. participation, satisfaction and perceived efficacy of programme) met } \\
\text { the inclusion criteria for this review }\end{array}$ \\
\hline Chambers 2005 & Not a mass media intervention \\
\hline Chiauzzi 2008 & $\begin{array}{l}\text { This study assesses the effectiveness of an online stress management tool. Outcomes do not include substance } \\
\text { use, intention to use or any other outcome relevant to this review }\end{array}$ \\
\hline Collins 1991 & This paper aims to prevent alcohol abuse \\
\hline Cook 1999 & Review of books and media, not of studies \\
\hline David 2006 & $\begin{array}{l}\text { Evaluated intervention is adolescent discussion about anti-drug advertisements, not advertisements them- } \\
\text { selves }\end{array}$ \\
\hline DeJong 1999 & $\begin{array}{l}\text { This paper raises concern about the Office of National Drug Control Policy (ONDCP)'s National Youth } \\
\text { Anti-Drug Media Campaign without reporting results of its effectiveness assessment }\end{array}$ \\
\hline Di Noia 2003 & $\begin{array}{l}\text { The majority of recruited professionals were older than } 26 \text { and the assessed outcomes are not among those } \\
\text { needed for inclusion }\end{array}$ \\
\hline Donohew 2000 & $\begin{array}{l}\text { The aim of the study is to understand the relationship between mediators (sensation-seeking and decision- } \\
\text { making processes) and alcohol and risky sexual behaviours in adolescents }\end{array}$ \\
\hline Epstein 1999 & Survey with control group but without pre-intervention questionnaire \\
\hline Erceg-Hurn 2008 & $\begin{array}{l}\text { It is not possible to compare different years due to the different methodology used in surveys (see also } \\
\text { commentary paper Erceg-Hurn 2008) }\end{array}$ \\
\hline Everett 1995 & $\begin{array}{l}\text { This study does not evaluate intervention effectiveness but matching between HSV/LSV interventions and } \\
\text { HSV/LSV subjects }\end{array}$ \\
\hline Flay 2000 & Reviews of mainly anti-tobacco media-, school- and community-based interventions \\
\hline Hannon 2000 & $\begin{array}{l}\text { Narrative review of key African American community values and provides recommendations as to how this } \\
\text { information might be incorporated into the development of anti-drug messages and materials targeted at } \\
\text { African Americans }\end{array}$ \\
\hline Harrington 2003 & $\begin{array}{l}\text { This study does not evaluate intervention effectiveness but matching between HSV/LSV interventions and } \\
\text { HSV/LSV subjects }\end{array}$ \\
\hline Helme 2007 & Intervention was an anti-smoking campaign \\
\hline Johnson 1990 & The mass media intervention was administered to both study groups \\
\hline Jordan 2005 & This study design (survey) does not allow us to evaluate intervention effectiveness \\
\hline
\end{tabular}

Media campaigns for the prevention of illicit drug use in young people (Review)

Copyright (c) 2013 The Cochrane Collaboration. Published by John Wiley \& Sons, Ltd. 
(Continued)

\begin{tabular}{l|l}
\hline Kang 2009 & $\begin{array}{l}\text { This study is an evaluation of the perceived effectiveness of specific elements of the interventions, not the } \\
\text { effectiveness of whole interventions on outcome variables included in the protocol for this review }\end{array}$ \\
\hline Know the Score 2007 & $\begin{array}{l}\text { For the } 2 \text { cocaine reports: the } 4 \text { study waves differed slightly but in many respects (age and working status } \\
\text { of respondents, survey locations and, more importantly, survey questions) } \\
\text { For the } 2 \text { heroin reports: respondent age is not fully comparable across study waves. Additionally, participants } \\
\text { in waves } 1 \text { and } 3 \text { were older than } 25\end{array}$ \\
\hline Lorch 1994 & $\begin{array}{l}\text { No pretest drug-related measure was taken. This study aims to predict responses to PSA and drug use by } \\
\text { different sensation-seeking profiles }\end{array}$
\end{tabular}
different sensation-seeking profiles

\begin{tabular}{|c|c|}
\hline Lubman 2007 & Narrative review on substance addiction prevention. Data were not presented here \\
\hline Marsiglia 2009 & This study evaluates a school-based intervention which has no media-related component \\
\hline Myers 2006 & Not a prevention intervention. It does not include illicit drug-related outcomes \\
\hline Palmgreen 2007 & $\begin{array}{l}\text { This study does not evaluate intervention effectiveness but matching between the intervention and HSV/ } \\
\text { LSV subjects }\end{array}$ \\
\hline Pentz 1990 & The fffect of the mass media component could not be disentangled from other components \\
\hline Ramirez 1999 & $\begin{array}{l}\text { Description of theoretical basis, development and implementation of 'Mirame!/Look at Me!' media- and } \\
\text { school-based programme for substance abuse among Hispanic youth. However, the programme's effectiveness } \\
\text { was not assessed }\end{array}$ \\
\hline Reis 1994 & Survey. This study design does not allow us to evaluate intervention effectiveness \\
\hline Ruggiero 2006 & Participants are older than 26 \\
\hline Schmeling 1980 & Intervention targets prescription drug abusers \\
\hline Siegel 2008 & No blank control, one group focusing on physical harms of inhalant use, the other focusing on social harms \\
\hline Skinner 1995a & The outcome (perceived persuasiveness) is not among the outcome measures included in our protocol \\
\hline Sloboda 2006 & This book does not include data on studies evaluating mass media programmes \\
\hline Spitzer 2010 & Outcomes concern 'values' and therefore do not meet the inclusion criteria \\
\hline Stephenson 2002 & $\begin{array}{l}\text { The aim of this study was to find predictors of exposure from an anti-marijuana media campaign, not to } \\
\text { evaluate the effectiveness of the campaign }\end{array}$ \\
\hline Stephenson $2002 \mathrm{a}$ & CBA study aiming to link perceived message sensation value and viewer's reaction to an anti-heroin PSA \\
\hline Stephenson 2003 & ing to evaluate sensation-seeking as a moderating variable \\
\hline
\end{tabular}

Media campaigns for the prevention of illicit drug use in young people (Review)

Copyright @ 2013 The Cochrane Collaboration. Published by John Wiley \& Sons, Ltd. 
(Continued)

\begin{tabular}{l|l}
\hline Stephenson 2005 & This study analyses the content of ads but does not assess their effectiveness \\
\hline Stevens 1996 & School-based intervention with added community activities \\
\hline Stryker 2003 & $\begin{array}{l}\text { Ecological study about the impact of media coverage of the negative consequences of marijuana use. This } \\
\text { study does not assess the effectiveness of a single prevention intervention }\end{array}$ \\
\hline Sussman 1987 & Survey with a control group but without a pre-intervention questionnaire \\
\hline Tait 2010 & Systematic review on Internet-based interventions for the treatment of alcohol misuse \\
\hline Taylor 1984 & $\begin{array}{l}\text { Outcomes in the pilot study (the statewide intervention was not evaluated) were knowledge, attitudes and } \\
\text { behaviours about friendships and human relationships, not substance use/misuse }\end{array}$ \\
\hline Varshavsky 2003 & Qualitative content analysis of a national campaign \\
\hline Werch 2010 & Not a mass media intervention \\
\hline
\end{tabular}

CBA: controlled before and after (study)

PSA: public service announcement

HSV: high sensation value

LSV: low sensation value

\section{Characteristics of studies awaiting assessment [ordered by study ID]}

\section{Block 2002}

Methods

\section{Participants}

Interventions

Outcomes

Notes We contacted authors for results and are waiting for a response

Duncan 2000

Methods

Participants

Interventions

Media campaigns for the prevention of illicit drug use in young people (Review) 


\section{Duncan 2000 (Continued)}

Outcomes

Notes We contacted authors for results and are waiting for a response

Flay 1986

Methods

Participants

Interventions

Outcomes

Notes We were unable to retrieve the paper's full text

\section{Longshore 2006}

Methods

Participants

Interventions

Outcomes

Notes We contacted authors for results and are waiting for a response

Marsch 2007

\begin{tabular}{l|l}
\hline Methods \\
\hline Participants \\
\hline Interventions \\
\hline Outcomes & \\
\hline Notes & We were unable to retrieve the paper's full text \\
\hline
\end{tabular}


Moore 2011

Methods

Participants

Interventions

Outcomes

Notes We were unable to retrieve the paper's full text

Moreno 2009

Methods

Participants

Interventions

Outcomes

Notes We contacted authors for results and are waiting for a response

\section{Skinner 1995}

Methods

Participants

Interventions

Outcomes

Notes We were unable to retrieve the paper's full text

Williams 2005

Methods

Participants

Interventions

Outcomes

Notes We contacted authors for results and are waiting for a response 
DATA ANDANALYSES

Comparison 1. Mass media versus no mass media intervention (RCT)

\begin{tabular}{lcclll} 
Outcome or subgroup title & $\begin{array}{c}\text { No. of } \\
\text { studies }\end{array}$ & $\begin{array}{c}\text { No. of } \\
\text { participants }\end{array}$ & \multicolumn{1}{c}{ Statistical method } & Effect size \\
\hline 1 Drug use & 5 & 5470 & Std. Mean Difference (IV, Random, 95\% CI) & $-0.02[-0.15,0.12]$ \\
2 Intention to use drugs & 4 & 1270 & Std. Mean Difference (IV, Fixed, 95\% CI) & $-0.07[-0.19,0.04]$ \\
\hline
\end{tabular}

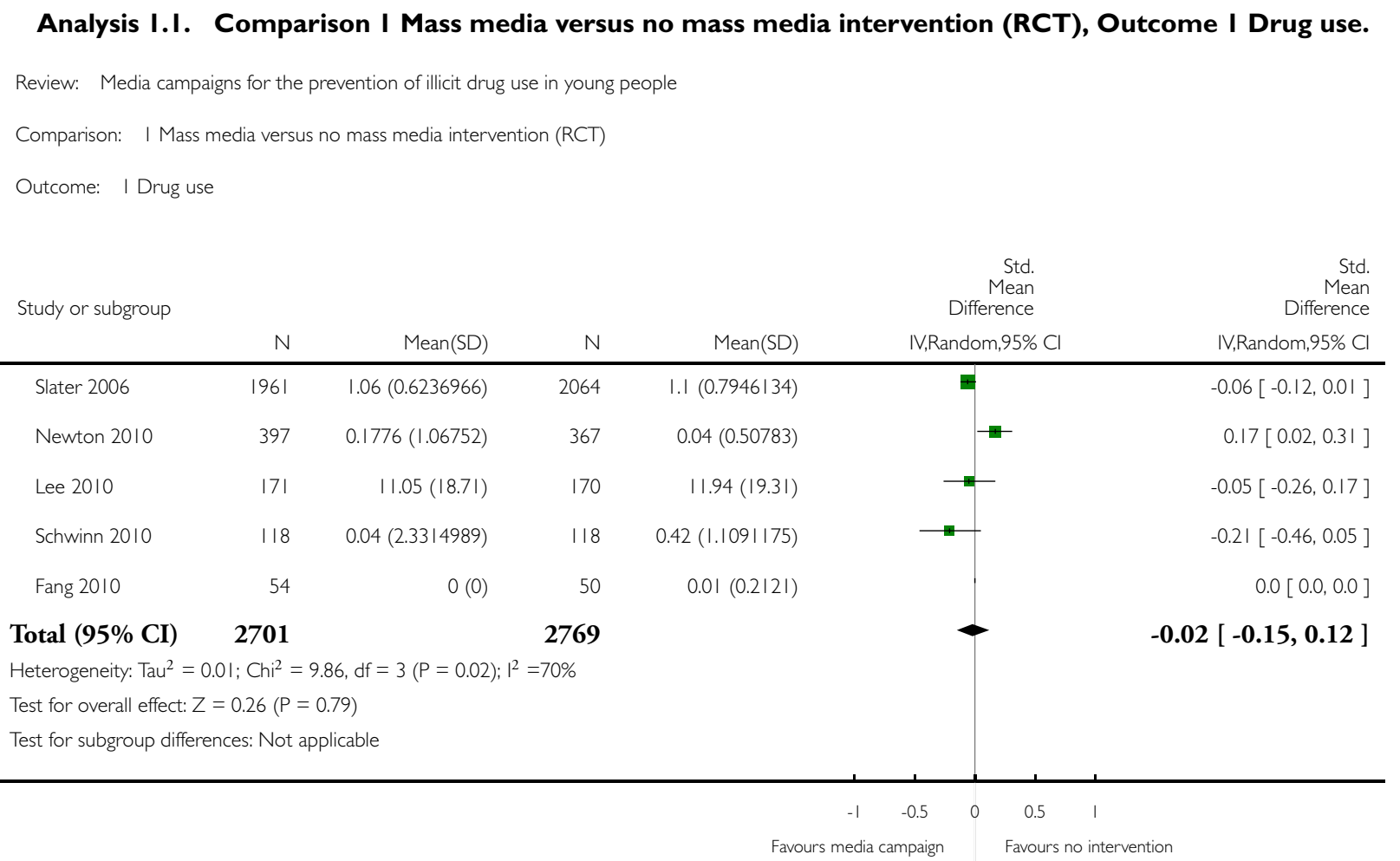




\section{Analysis I.2. Comparison I Mass media versus no mass media intervention (RCT), Outcome 2 Intention to use drugs.}

Review: Media campaigns for the prevention of illicit drug use in young people

Comparison: I Mass media versus no mass media intervention (RCT)

Outcome: 2 Intention to use drugs

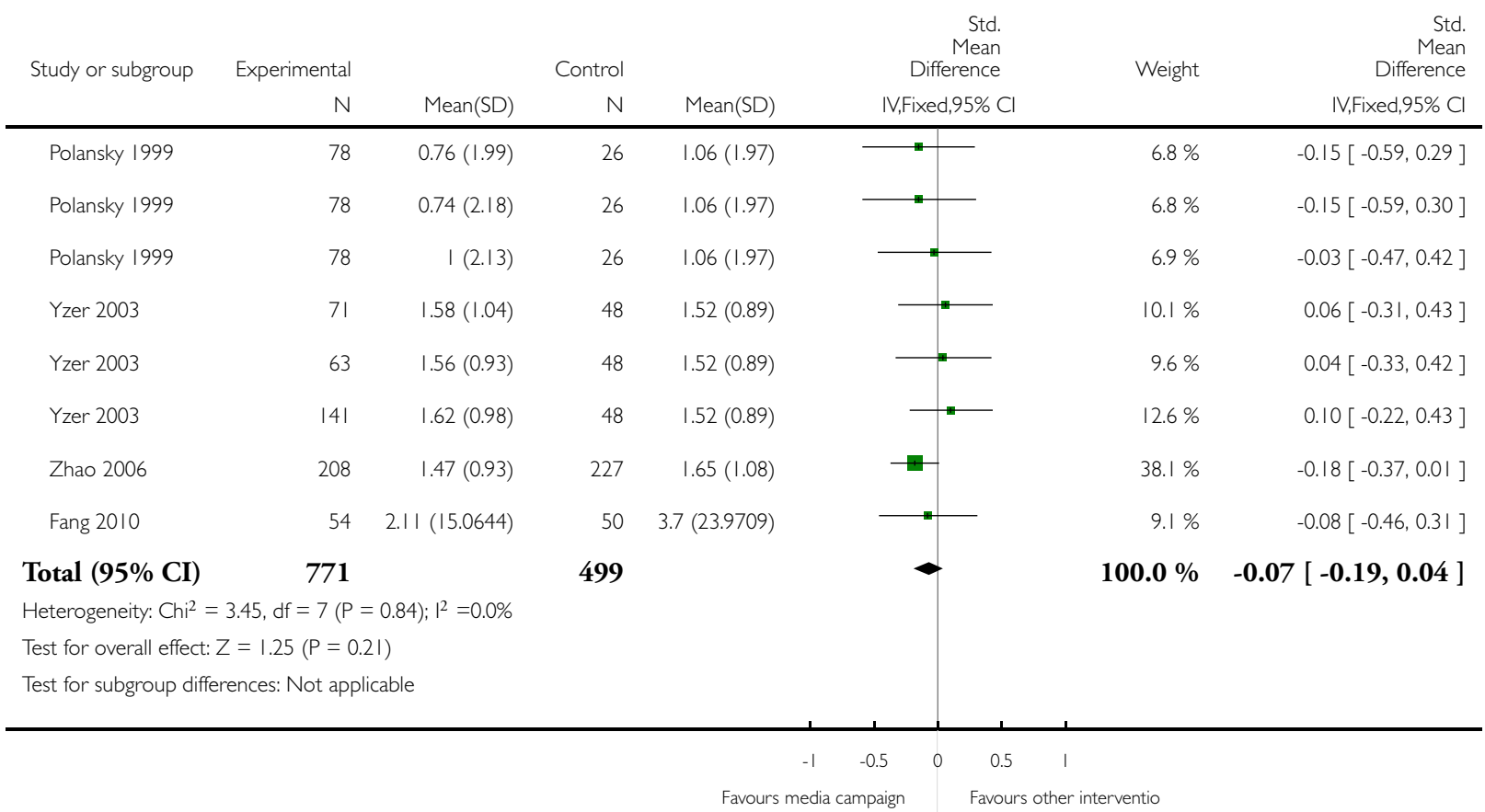

\section{A D DITIONAL TABLES}

Table 1. 'Risk of bias' assessment of interrupted time series studies

Miller 2000

\begin{tabular}{|c|c|c|}
\hline Criterion & Score & Notes \\
\hline a) Protection against secular changes & & \\
\hline $\begin{array}{l}\text { The intervention is independent of other } \\
\text { changes }\end{array}$ & Done & $\begin{array}{l}\text { "The usual environmental influences such as prices, taxes, state regulations, } \\
\text { campus policies, and enforcement did not change substantially during the } \\
\text { study period. Neither was there any reason to expect that students on the } \\
\text { two campuses would respond differentially to anonymous surveys. The only } \\
\text { obvious difference between the two campuses that might be expected to } \\
\text { affect substance use differentially was the implementation of the prevention }\end{array}$ \\
\hline
\end{tabular}


Table 1. 'Risk of bias' assessment of interrupted time series studies (Continued)

program at UNM", page 756

There are sufficient data points to enable Not done 2 data points (before and after) reliable statistical inference

Formal test for trend. Complete this section Done

if authors have used ANOVA modelling

b) Protection against detection bias

Intervention unlikely to affect data collec- Done tion

"All questionnaires were completed anonymously. To encourage participation, those who returned the survey (by mail) were entered into a lottery for cash prizes by separating a numbered ticket, returning one part with the completed survey and retaining the other half. Winning numbers were announced through the campus newspaper, the Daily Lobo. As an additional incentive for the follow-up survey, respondents were invited to participate in a contest to guess the actual levels of alcohol/drug use on campus, as revealed by the first survey", page 750

\begin{tabular}{|c|c|c|}
\hline Blinded assessment of primary outcome(s) & Done & Anonymous surveys, page 750 \\
\hline c) Completeness of data set & Done & $\begin{array}{l}\text { "At baseline (fall) assessment, } 1,400 \text { surveys were distributed to enrolled } \\
\text { UNM students, a sample of approximately } 6 \% \text { selected randomly by the } \\
\text { university s computerized mailing list program. Of these, } 567 \text { surveys were } \\
\text { returned and usable ( } 41 \%) \text {. At the control campus, } 1,080 \text { surveys were } \\
\text { distributed to a random sample of students, } 457 \text { of whom returned them } \\
(42.3 \%) \text {. [.. The return rates were } 431(31 \%) \text { at UNM and } 434(34 \%) \text { at } \\
\text { NMSU", page } 751\end{array}$ \\
\hline d) Reliable primary outcome measure(s) & Done & $\begin{array}{l}\text { "Use measures ( } 14 \text { items) included a frequency (number of drinking days per } \\
30 \text { ) and quantity index of drinking (number of standard drinks consumed } \\
\text { per drinking occasion; range: } 0-15 \text { ) that were multiplied to form a single } \\
\text { quantity frequency measure (number of drinks per month) [..]", page } 750 \\
\text { "Problem measures included } 14 \text { indicators of alcohol dependence and ad- } \\
\text { verse consequences of heavy drinking or illicit drug use in the prior year. [. } \\
\text {.]", page } 750 \\
\text { "Risk assessment included } 13 \text { items regarding the extent to which students } \\
\text { perceived risk or consequences related to alcohol or other drug use [..]", } \\
\text { page } 750\end{array}$ \\
\hline
\end{tabular}

\section{Palmgreen 2001 (includes Stephenson 1999)}

\begin{tabular}{lll}
\hline Criterion & Score & Notes \\
\hline
\end{tabular}

a) Protection against secular changes

Media campaigns for the prevention of illicit drug use in young people (Review) 
Table 1. 'Risk of bias' assessment of interrupted time series studies (Continued)

The intervention is independent of other Unclear changes

There are sufficient data points to enable Done 32 data points reliable statistical inference

Formal test for trend. Complete this section Done ANOVA modelling was used. See from page 186 on if authors have used ANOVA modelling

b) Protection against detection bias

Intervention unlikely to affect data collec- Done tion

Blinded assessment of primary outcome(s) Done
Methodology of data collection is not reported to have changed across data points

Anonymous computer-administered questionnaire (p. 293)

c) Completeness of data set Unclear

d) Reliable primary outcome measure(s) Done 30-day use of marijuana, attitudes, beliefs, intentions

Idaho Meth 2010, Colorado Meth 2011, Georgia Meth 2011, Hawaii Meth 2011 and Wyoming Meth 2011

\begin{tabular}{l|l}
\hline Criterion & Score $\quad$ Notes \\
\hline a) Protection against secular changes & \\
\hline
\end{tabular}

The intervention is independent of other Unclear changes

There are sufficient data points to enable Done reliable statistical inference

Data points for each study ranged from 2 to 4 including only one baseline survey. However, overall, there are a sufficient number of observations

Formal test for trend. Complete this section Not done

if authors have used ANOVA modelling

\section{b) Protection against detection bias}

\begin{tabular}{lll}
\hline $\begin{array}{l}\text { Intervention unlikely to affect data collec- } \\
\text { tion }\end{array}$ & Done & $\begin{array}{l}\text { Despite some slight changes, methodology of data collection is consistent } \\
\text { across studies and across data points }\end{array}$ \\
\hline Blinded assessment of primary outcome(s) & Done & Anonymous questionnaires \\
\hline c) Completeness of data set & Unclear & Not applicable \\
\hline d) Reliable primary outcome measure(s) & Done & Past-month use of marijuana, attitudes, perceptions
\end{tabular}


Table 1. 'Risk of bias' assessment of interrupted time series studies (Continued)

\section{Carpenter 2011}

\begin{tabular}{|c|c|c|}
\hline Criterion & Score & Notes \\
\hline
\end{tabular}

The intervention is independent of other Done Adjustment by many individual and market variables (page 949) changes

There are sufficient data points to enable Not done 3 data points (page 949)

reliable statistical inference

Formal test for trend. Complete this section Done "multivariate logistic regression" (page 949)

if authors have used ANOVA modelling

b) Protection against detection bias

\begin{tabular}{|c|c|c|}
\hline $\begin{array}{l}\text { Intervention unlikely to affect data collec- } \\
\text { tion }\end{array}$ & Done & Ads were broadcasted independently on the surveys \\
\hline Blinded assessment of primary outcome(s) & Done & Monitoring the Future (MTF) surveys used anonymous questionnaires \\
\hline c) Completeness of data set & Unclear & \\
\hline d) Reliable primary outcome measure(s) & Done & Past-month and lifetime marijuana use (page 951) \\
\hline
\end{tabular}

Table 2. 'Risk of bias' assessment of cohort studies (Hornik 2006, Scheier 2010, Slater 2011)

Hornik 2006

\begin{tabular}{|c|c|c|}
\hline Criterion & Score/Info & Notes \\
\hline \multicolumn{3}{|l|}{ In a well-conducted cohort study: } \\
\hline $\begin{array}{l}\text { The study addresses an appropriate and } \\
\text { clearly focused question }\end{array}$ & Well covered & $\begin{array}{l}\text { "We examined the cognitive and behavioral } \\
\text { effects of the National Youth Anti-Drug } \\
\text { Media Campaign on youths aged } 12.5 \text { to } \\
18 \text { years and report core evaluation results", } \\
\text { abstract }\end{array}$ \\
\hline
\end{tabular}

Selection of subjects

The 2 groups being studied are selected Well covered from source populations that are comparable in all respects other than the factor under investigation
"The sample was selected to provide an efficient and nearly unbiased cross-section of US youths and their parents. Respondents

Media campaigns for the prevention of illicit drug use in young people (Review)

Copyright (c) 2013 The Cochrane Collaboration. Published by John Wiley \& Sons, Ltd. 
Table 2. 'Risk of bias' assessment of cohort studies (Hornik 2006, Scheier 2010, Slater 2011)

were selected through a stratified 4-stage probability sample design: 90 primary sampling units-typically county size-were selected at the first stage, geographical segments were selected within the sampled primary sampling units at the second stage, households were selected within the sampled segments at the third stage, and then, at the final stage, 1 or 2 youths were selected within each sampled household, as well as 1 parent in that household.", page 222930

The study indicates how many of the peo- Well covered

Evaluation of the National Youth Antiple asked to take part did so, in each of the groups being studied

Drug Media Campaign: 2004 Report of Findings, Appendix A, page A-6, table A-1 and page A-11 tables A-8 to A-10

The likelihood that some eligible subjects Well covered might have the outcome at the time of en-

"Analyses were restricted to youths who rolment is assessed and taken into account were nonusers of marijuana at the current round (for cross-sectional analyses) or at the in the analysis previous round (for lagged analyses).", page 2232

What percentage of individuals or clus- $35 \%$ ters recruited into each arm of the study

"The overall response rate among youths for the first round was $65 \%$, with $86 \%$ to $93 \%$ of still eligible youths interviewed in subsequent rounds.", page 2230

dropped out before the study was completed

Evaluation of the National Youth AntiDrug Media Campaign: 2004 Report of Findings, page 2-12, table 2-A "Completed interviews by wave"

Comparison is made between full partici- Not reported pants and those lost to follow-up, by expo-

sure status

Assessment

The outcomes are clearly defined

Well covered

"For 3 reasons, all drug-related measures reported here relate to marijuana use. [..] Four measures or indices represented the following constructs: (1) marijuana intentions, (2) marijuana beliefs and attitudes, (3) social norms, and (4) self-efficacy to resist use.", page 2230

The assessment of outcome is made blind Not applicable to exposure status

Blinding to exposure status was not applicable for this study

Media campaigns for the prevention of illicit drug use in young people (Review)

Copyright (c) 2013 The Cochrane Collaboration. Published by John Wiley \& Sons, Ltd. 
Table 2. 'Risk of bias' assessment of cohort studies (Hornik 2006, Scheier 2010, Slater 2011)

Where blinding was not possible, there is Well covered sure status could have influenced the assessment of outcome

The measure of assessment of exposure is Well covered reliable some recognition that knowledge of expo-

"A measure of general exposure to antidrug advertising was derived from responses to questions about advertising recall for each medium or media grouping: television and radio, print, movie theatres or videos, and outdoor advertising.", page 2230

"For 3 reasons, all drug-related measures reported here relate to marijuana use.", page 2230

Evidence from other sources is used to Well covered demonstrate that the method of outcome assessment is valid and reliable

"For 3 reasons, all drug-related measures reported here relate to marijuana use. First, marijuana is by far the illicit drug most heavily used by youths. Second, for other drugs, the low levels of use meant that the NSPY sample sizes were not large enough to detect meaningful changes in use with adequate power. Third, to the extent that the campaign did target a specific drug, it was almost always marijuana. [..] The cognitive measures were developed on the basis of 2 health behavior theories, the theory of reasoned action and social cognitive theory", page 2230

Exposure level or prognostic factor is as- Well covered sessed more than once

Confounding

The main potential confounders are iden- Well covered tified and taken into account in the design and analysis
"3 nationally representative cohorts of US youths aged 9 to 18 years were surveyed at home 4 times.”, abstract
"Potential confounder measures. The analyses employed propensity scoring for confounder control by weighting adjustments, 9-14 incorporating a wide range of standard demographic variables and variables known to be related to youths' drug use or thought likely to be related to exposure to antidrug messages. Propensity scores were developed for the general and specific exposure measures. More than 150 variables were considered possible confounders.", page 2231

Statistical analysis 
Table 2. 'Risk of bias' assessment of cohort studies (Hornik 2006, Scheier 2010, Slater 2011)

Overall assessment of the study

How well was the study done to minimise the risk of bias or confounding, and to establish a causal relationship between exposure and effect?

Code,+++ , or -
Propensity scoring from 150 confounders, page 2231

This study includes very good control for possible confounders tions, your evaluation of the methodology

Yes used, and the statistical power of the study, are you certain that the overall effect is due to the exposure being investigated?
Are the results of this study directly appli- Unclear cable to the patient group targeted in this guideline?
Results are applicable to US youth; it is unclear whether they are generalisable outside the US

Description of the study

Do we know who the study was funded by? Public Funds (NIDA), Government (Congress)
"Research for and preparation of this article were supported by the National Institute on Drug Abuse (grants 3-N01-DA085063002 and 1-R03-DA-020893-01). The evaluation of the National Youth Anti-Drug Media Campaign was funded by Congress as part of the original appropriation for the campaign. The White House Office of $\mathrm{Na}$ tional Drug Control Policy directly supervised the campaign. The National Institute on Drug Abuse supervised the evaluation; Westat, with the Annenberg School for Communication at the University of Pennsylvania as a subcontractor, received the contract. All authors were funded for this evaluation and other projects by the National Institute on Drug Abuse.”, page 2235

How many centres are patients recruited USA as a whole from?

"90 primary sampling units-typically county size-were selected at the first stage, geographical segments were selected within the sampled primary sampling units at the second stage, households were selected within the sampled segments at the third stage, and then, at the final stage, 1 or 2 youths were selected within each sampled household, as well as 1 parent in that house- 
hold.”, page 2230

From which countries are patients selected? USA

(Select all those involved. Note additional countries after 'Other')

What is the social setting (i.e. type of envi- Mixed ronment in which they live) of patients in the study?
"More than 150 variables were considered possible confounders. [..] They include [.. ] urban-rural residency; [..]”, page 2231
What criteria are used to decide who should 4-stage selection be INCLUDED in the study?
"Respondents were selected through a stratified 4-stage probability sample design: 90 primary sampling units-typically county size-were selected at the first stage, geographical segments were selected within the sampled primary sampling units at the second stage, households were selected within the sampled segments at the third stage, and then, at the final stage, 1 or 2 youths were selected within each sampled household, as well as 1 parent in that household.", page 2229-30

What criteria are used to decide who should be EXCLUDED from the study?
"As mentioned previously, youth residing in group quarters were not eligible for selection in any of the three recruitment waves. Thus, youth living in boarding schools and college dormitories were excluded from the scope of the survey. This exclusion was made because it was felt that dormitory residents could not be easily interviewed at their parents' homes and that their experiences were so", Report, A-10
What intervention or risk factor is investi- The National Youth Anti-Drug Media gated in the study? (Include dosage where Campaign appropriate)
What comparisons are made in the study (i.e. what alternative treatments are used to compare the intervention/exposure with). Include dosage where appropriate
Lower exposure versus higher exposure to anti-drug campaign
"The analyses reported here were based on 3 types of measures: recalled exposure to antidrug messages aired by the campaign and other sources; cognitions and behavior related to marijuana, as outcomes; and individual and household characteristics, including a wide range of variables known to be related to drug cognitions and use and to exposure to antidrug messages.", page 2230 


\begin{abstract}
What methods were used to randomise pa- Randomisation: not applicable, but tients, blind patients or investigators, and propensity scoring was employed to conceal the randomisation process from Blinding of patients: not applicable investigators?

Blinding of investigators: not reported

Randomisation concealment: not applica-

ble
\end{abstract}

How long did the active phase of the study September 1999 to June 2004 (58 months) last?

How long were patients followed up for, November 1999 to June 2004 (56 months) during and after the study?

List the key characteristics of the patient Representative of US youths aged 9 to 18 population. Note if there are any significant differences between different arms of the trial

Record the basic data for each arm of the study. If there are more than 4 arms, note data for subsequent arms at the bottom of the page

Record the basic data for each IMPORTANT outcome in the study. If there are more than 4, note data for additional outcomes at the bottom of the page

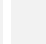

"The sample was selected to provide an efficient and nearly unbiased cross-section of US youths and their parents", page 2229

Tables 1-4, pages 2233-4

Notes. Summarise the authors' conclusions. Through June 2004, the campaign is unAdd any comments on your own assessment of likely to have had favourable effects on the study, and the extent to which it answers youths and may have had delayed unyour question favourable effects

The evaluation challenges the usefulness of the campaign

Scheier 2010

\begin{tabular}{|c|c|c|}
\hline Criterion & Score/Info & Notes \\
\hline \multicolumn{3}{|l|}{ In a well-conducted cohort study: } \\
\hline $\begin{array}{l}\text { The study addresses an appropriate and } \\
\text { clearly focused question }\end{array}$ & Well covered & $\begin{array}{l}\text { "In this study, we examined whether aware- } \\
\text { ness (recall) of the National Youth Anti- } \\
\text { Drug Media Campaign (NYADMC) ben- } \\
\text { efited youth by attenuating their drug use. } \\
\text { ", abstract }\end{array}$ \\
\hline
\end{tabular}

\section{Selection of subjects}

Media campaigns for the prevention of illicit drug use in young people (Review)

Copyright (c) 2013 The Cochrane Collaboration. Published by John Wiley \& Sons, Ltd.

Tables 1-4, pages 2233-4 
The 2 groups being studied are selected Well covered from source populations that are comparable in all respects other than the factor under investigation
Same as Hornik 2008 ("The sample was selected to provide an efficient and nearly unbiased cross-section of US youths and their parents. Respondents were selected through a stratified 4-stage probability sample design: 90 primary sampling unitstypically county size-were selected at the first stage, geographical segments were selected within the sampled primary sampling units at the second stage, households were selected within the sampled segments at the third stage, and then, at the final stage, 1 or 2 youths were selected within each sampled household, as well as 1 parent in that household.”, page 2229-30)
The study indicates how many of the peo- Well covered ple asked to take part did so, in each of the groups being studied

Well covered

The likelihood that some eligible subjects might have the outcome at the time of enrolment is assessed and taken into account in the analysis

Same as Hornik 2008 (Evaluation of the National Youth Anti-Drug Media Campaign: 2004 Report of Findings, Appendix A, page A- 6 , table A- 1 and page A- 11 tables A-8 to A-10)

Same questionnaire was administered at baseline and at follow-up. "National Survey of Parents and Youth (NSPY) [..] could be used to assess youths' awareness of the campaign messages and monitor any corresponding changes in drug use trends.", page 241-2

What percentage of individuals or clus- $35 \%$ ters recruited into each arm of the study dropped out before the study was completed
Same as Hornik 2008 ("The overall response rate among youths for the first round

was $65 \%$, with $86 \%$ to $93 \%$ of still eligible youths interviewed in subsequent rounds ", page 2230 Evaluation of the National Youth Anti-Drug Media Campaign: 2004 Report of Findings, page 2-12, table 2-A "Completed interviews by wave")

"Attrition analyses were structured to determine whether certain factors operate systematically to cause dropout from the study. Proportional analyses using the v2 test were used for cross tabulation of binary measures and logistic regression modelling to examine the optimal predictors of retention (coded ' 1 ' stay and '0' dropout). We 
Table 2. 'Risk of bias' assessment of cohort studies (Hornik 2006, Scheier 2010, Slater 2011)

used the WesVar software program to estimate logistic regression models of panel attrition. This statistical modelling program enables us to adjust (through poststratification) the sample variance estimators for the undersampling of primary sampling units and correct any bias in parameter estimates related directly to the complex sampling design (using replicate variance estimators to adjust standard errors for design effects) Proportional tests indicated that panel youth were significantly more likely to be female, smoke more cigarettes, drink alcohol, and smoke marijuana (all v2 proportional tests significant at the $\mathrm{p} .0001$ ) compared with dropout youth. Given the large number of variables possibly related to retention status, logistic models were run separately for five individual domains (demographics, campaign awareness, drug use, school-related factors, and psychosocial risk).7 Following tests of the individual domains, we culled only significant predictors and tested these in a combined model predicting retention. The final model indicated that retained youth were less at risk for marijuana use (unstandardized $b=$ $-3.51, \mathrm{p}<=.0001, \mathrm{OR}=.03)$, engaged in more antisocial behavior (evidencing suppression: $[\mathrm{b}=.23, \mathrm{p}<=.0001, \mathrm{OR}=1.26]$ ), spent fewer hours listening to the radio on a daily basis $(\mathrm{b}=-.09, \mathrm{p}<=.01, \mathrm{OR}=.91)$, and were more likely to have attended school in the past year $(\mathrm{b}=1.05, \mathrm{p}<=.01, \mathrm{OR}=2.87)$ compared with their dropout counterparts. Using the Cox-Snell likelihood pseudo-R2 statistic, the model accounted for $12 \%$ of the variance in retention status, $\mathrm{F}(14,87)=$ 12.127, $\mathrm{p}<=.0001$.",

page 250

Assessment

The outcomes are clearly defined

Well covered

"Assessment of alcohol and drug use relied on an Anonymous Computer Assisted Selfreport Interview (ACASI). Two alcohol use items 6 assessed being drunk or high ("How many times were you drunk or very high from alcohol in the last 12 months?") with

Media campaigns for the prevention of illicit drug use in young people (Review) 
Table 2. 'Risk of bias' assessment of cohort studies (Hornik 2006, Scheier 2010, Slater 2011)

response categories ranging from "I don't use alcohol" (0) through " 40 or more occasions" (7); and heavy alcohol use based on a measure of binge drinking ("How many days have you had five or more drinks in the last 30 days?") with response categories ranging from "I don't drink" (0) through "10 or more times" (6). Cigarette use was assessed with a single item ("How many cigarettes smoked a day during the last 30 days?") with response categories ranging from "None" (0) through "More than 35 per day, about 2 packs or more" (7). A single frequency item assessed marijuana involvement ("How many times have you used marijuana in the last 12 months?") with response categories ranging from "I have never used marijuana" $(0)$ through " 40 or more occasions“ (6).”, page 248

The assessment of outcome is made blind Not applicable Blinding to exposure status was not applito exposure status cable for this study

Where blinding was not possible, there is Not reported some recognition that knowledge of exposure status could have influenced the assessment of outcome

The measure of assessment of exposure is Well covered reliable
"Turning to the campaign awareness parameters, we see two findings worth noting. First, growth in campaign awareness is positive for the earlier years (12 to 14 ), except for television viewing behavior, which had a slope not significantly different from zero. As these youth became older (14 to 18) , their awareness declined for every media venue except specific recall (videos shown on laptops) and radio listening behavior. Also, the magnitude of the slope terms were considerably larger at the younger age for recall of stories about drugs and youth, brand awareness, specific recall, and radio listening but larger in magnitude for television (declining) as these youth transitioned to high school.", page 253

"Figure 2 graphically presents a generic template for testing the bivariate cohort growth models. Again, two slope trends are posited to capture the different rates of 
Table 2. 'Risk of bias' assessment of cohort studies (Hornik 2006, Scheier 2010, Slater 2011)

growth for youth when they were younger versus when they were older, and this is repeated for both drug use (D) and awareness (A) measures.”, page 253

Evidence from other sources is used to Well covered demonstrate that the method of outcome assessment is valid and reliable
"Assessment of alcohol and drug use relied on an Anonymous Computer Assisted Selfreport Interview (ACASI). Two alcohol use items 6 assessed being drunk or high ("How many times were you drunk or very high from alcohol in the last 12 months?") with response categories ranging from "I don't use alcohol“ (0) through " 40 or more occasions" (7); and heavy alcohol use based on a measure of binge drinking ("How many days have you had five or more drinks in the last 30 days?") with response categories ranging from "I don't drink" (0) through "10 or more times" (6). Cigarette use was assessed with a single item ("How many cigarettes smoked a day during the last 30 days?") with response categories ranging from "None" (0) through "More than 35 per day, about 2 packs or more" (7). A single frequency item assessed marijuana involvement ("How many times have you used marijuana in the last 12 months?") with response categories ranging from "I have never used marijuana" (0) through " 40 or more occasions“ (6).”, page 248

Yes: 4 rounds of data collection. Table 1,

page 249
Exposure level or prognostic factor is as- Well covered sessed more than once

\section{Confounding}

The main potential confounders are iden- Not reported tified and taken into account in the design and analysis

Statistical analysis

Have confidence intervals been provided? No

Page 264

Overall assessment of the study

How well was the study done to minimise the risk of bias or confounding, and to establish a causal relationship between expo- “...there was no "intervention" to speak of, but rather the campaign took shape as a naturalistic observational study conducted 
sure and effect?

Code,+++ , or - at a particular point in time with no clear demarcation from various historical influences that could affect patterns of reported drug use", page 264
Taking into account clinical considerations, your evaluation of the methodology used, and the statistical power of the study, are you certain that the overall effect is due to the exposure being investigated?
No, because no adjustment for confounders was reported
Are the results of this study directly appli- Unclear cable to the patient group targeted in this guideline?
Results are applicable to US youth; it is unclear whether they are generalisable outside the US

\section{Description of the study}

Do we know who the study was funded by? No

How many centres are patients recruited USA as a whole from?
Same as Hornik 2008 ("90 primary sampling units-typically county size-were selected at the first stage, geographical segments were selected within the sampled primary sampling units at the second stage, households were selected within the sampled segments at the third stage, and then, at the final stage, 1 or 2 youths were selected within each sampled household, as well as 1 parent in that household.”, page 2230)

From which countries are patients selected? USA

(Select all those involved. Note additional countries after 'Other')

What is the social setting (i.e. type of envi- Mixed ronment in which they live) of patients in the study?
Same as Hornik 2008 ("More than 150 variables were considered possible confounders. [..] They include [..] urban-rural residency; [..]", page 2231)

Same as Hornik 2008 ("Respondents were selected through a stratified 4-stage probability sample design: 90 primary sampling units-typically county size-were selected at the first stage, geographical segments were selected within the sampled primary sampling units at the second stage, households were selected within the sampled segments at the third stage, and then, at the final 
Table 2. 'Risk of bias' assessment of cohort studies (Hornik 2006, Scheier 2010, Slater 2011)

stage, 1 or 2 youths were selected within each sampled household, as well as 1 parent in that household.”, page 2229-30)

What criteria are used to decide who should be EXCLUDED from the study?
Youth living in boarding schools and college dormitories
Same as Hornik 2008 ("As mentioned previously, youth residing in group quarters were not eligible for selection in any of the three recruitment waves. Thus, youth living in boarding schools and college dormitories were excluded from the scope of the survey. This exclusion was made because it was felt that dormitory residents could not be easily interviewed at their parents' homes and that their experiences were so", Report, Appendix A, A-10)
What intervention or risk factor is investi- The National Youth Anti-Drug Media gated in the study? (Include dosage where Campaign appropriate) "...there was no "intervention " to speak of, but rather the campaign took shape as a naturalistic observational study conducted at a particular point in time with no clear demarcation from various historical influences that could affect patterns of reported drug use", page 264
What comparisons are made in the study (i.e. what alternative treatments are used to compare the intervention/exposure with). Include dosage where appropriate
Varius models, e.g. see page 256

Exposure versus drug use
What methods were used to randomise patients, blind patients or investigators, and to conceal the randomisation process from investigators?
Randomisation: not applicable

Blinding of patients: not applicable

Blinding of investigators: not reported

Randomisation concealment: not applica-

ble

How long did the active phase of the study September 1999 to June 2004 (58 months)

last?

How long were patients followed up for, November 1999 to June 2004 (56 months) during and after the study?

List the key characteristics of the patient Representative of US youths aged 9 to 18 population. Note if there are any significant differences between different arms of the trial
Same as Hornik 2008 ("The sample was selected to provide an efficient and nearly unbiased cross-section of US youths and their parents", page 2229)

Record the basic data for each arm of the study.

If there are more than 4 arms, note data for

Table 2, page 251

subsequent arms at the bottom of the page

Media campaigns for the prevention of illicit drug use in young people (Review) 
Record the basic data for each IMPORTANT

Tables 3-4-5, pages $252-7$

outcome in the study. If there are more than

4, note data for additional outcomes at the bottom of the page

Notes. Summarise the authors' conclusions. Add any comments on your own assessment of the study, and the extent to which it answers your question
When they were younger, these youth accelerated their drug use and reported increasing amounts of campaign awareness. When they were older, [..] no effects for marijuana were significant but trended in the direction of increased awareness associated with declining drug use
"Behavior change is guided by the Theory of Reasoned Action (TRA: Ajzen \& Fishbein, 1973, 1977) and draws also from social persuasion (McGuire, 1961, 1966, 1968) and communication theories (Hovland, Janis, \& Kelley, 1953). According to the TRA, the influence of attitudes (i.e. , subjective evaluations of behavior consequences) and beliefs (subjective norms and behavioral outcomes or expectancies) on behavior is mediated through intentions (i. e., future intent to engage the behavior) . In other words, youth form impressions of whether drugs are good or bad, and they combine this information with normative beliefs (whether their close friends approve of drug use) and behavioral expectations (perceived benefits and negative consequences of drug use) toward drug use. These steps are necessary but not sufficient conditions, as the final decision to use drugs is guided by their behavioral willingness or intentions.", page 242

"To date, analyses of the media campaign efficacy have used traditional linear regression or correlation techniques to examine campaign effects. While this tactic has been useful to delineate the basic statistical associations between campaign awareness and drug use, a major weakness of this approach is that it fails to provide a developmental perspective and incorporate systematic features of change in either awareness or drug use.[..] Growth modelling is clearly a more definitive way to address the question of change and increasingly has been advocated as a means to assess prevention effects that unfold over time (Brown, Catalano, Fleming, Haggerty, \& Abbott, 2005; Mason, Kosterman, Hawkins, Haggerty, \& Spoth, 2003; Park et al., 2000; Taylor, Graham, Cumsille, \& Hansen, 2000). [..] The age 
Table 2. 'Risk of bias' assessment of cohort studies (Hornik 2006, Scheier 2010, Slater 2011)

mixture within each round makes it imperative to estimate growth using age- cohort models", page 242-3

Slater 2011

\section{Criterion}

Score/Info

Notes

In a well-conducted cohort study:

The study addresses an appropriate and Well covered

clearly focused question

“...(a) provide two simultaneous tests of autonomy and aspiration perceptions as mediators of impact on marijuana use as a consequence of exposure to each of these campaigns, b) conduct the first independent assessment of the ONDCP media campaign, which did not have a formal independent evaluation in place during the years of this study, and c) assess the simultaneous impact of a national campaign and a similar community/in-school effort.", page 12-13

Selection of subjects

The 2 groups being studied are selected Not reported from source populations that are comparable in all respects other than the factor under investigation
" 3,236 students participated in at least one survey, with $48 \%$ males, $52 \%$ females and a mean age at baseline of 12.4 years $(\mathrm{SD}=0.6) ; 75 \%$ were European-American, $11.5 \%$ African-American, and $13.5 \%$ of other racial backgrounds. One-quarter of the youth were of Hispanic ethnicity.", page 15

Only average: "The average rate of student participation in each school was $32 \%$ of total student enrolment, lower than the prior study because of stricter IRB requirements being imposed on recruitment procedures. $57.1 \%$ of respondents provided data at all four measurement occasions; $27.2 \%$ provided data on three, $9.4 \%$ provided data on two and $5.3 \%$ provided data on just one of the measurement occasions. Missed surveys appear to be a matter more of absenteeism or slips in getting students to survey sessions, than of panel mortality; $84.5 \%$ of participants filled out the wave 1 survey, 
Table 2. 'Risk of bias' assessment of cohort studies (Hornik 2006, Scheier 2010, Slater 2011)

$86.2 \%$ wave $2,86.1 \%$ wave 3 , and $81.3 \%$ wave $4 . "$, page 15

The likelihood that some eligible subjects might have the outcome at the time of enrolment is assessed and taken into account in the analysis
Well covered

What percentage of individuals or clus- $42.9 \%$ ters recruited into each arm of the study dropped out before the study was completed
"Lifetime use of marijuana was measured at each measurement wave [..]", page 15

\begin{abstract}
"The average rate of student participation in each school was $32 \%$ of total student enrolment, lower than the prior study because of stricter IRB requirements being imposed on recruitment procedures. $57.1 \%$ of respondents provided data at all four measurement occasions; $27.2 \%$ provided data on three, $9.4 \%$ provided data on two and $5.3 \%$ provided data on just one of the measurement occasions. Missed surveys appear to be a matter more of absenteeism or slips in getting students to survey sessions, than of panel mortality; $84.5 \%$ of participants filled out the wave 1 survey, $86.2 \%$ wave 2 , $86.1 \%$ wave 3 , and $81.3 \%$ wave 4 .", page 15
\end{abstract}

Comparison is made between full partici- Not reported pants and those lost to follow-up, by exposure status

\section{Assessment}

The outcomes are clearly defined
"Autonomy and Aspirations Inconsistent With Marijuana Use Autonomy inconsistent with marijuana use was measured using responses to four items following the phrase "Not using marijuana": 1) is a way to be true to myself; 2) is an important part of who I am; 3) is a way of being in control of my life; and 4) is a way of showing my own independence, where responses ranged from 1 = definitely disagree to 4 = definitely agree. Similarly, aspirations inconsistent with marijuana use were measured using the responses to three items following the phrase "Using marijuana would: 1) keep me from doing the things I want to; 2) mess up my plans for when I am older; and 3) get in the way of what is important to me." Because responses to each 
Table 2. 'Risk of bias' assessment of cohort studies (Hornik 2006, Scheier 2010, Slater 2011) (Continued)

scale's items were heavily skewed, with $82 \%$ of respondents selecting "definitely agree" for all aspiration items and $84 \%$ of respondents selecting "definitely agree" for all autonomy items, each scale was dichotomized such that a "1" was assigned if all responses to the scale items were "definitely agree" and a "0" otherwise. The Cronbach's alpha values (Cronbach 1951) for each dichotomized measure were 9 or greater at each of the four waves

Marijuana Use Lifetime use of marijuana was measured at each measurement wave using four questions: "How old were you the first time you used marijuana?", "How often in the last month have you used marijuana?", "How often in the last 3 months have you used marijuana?", and "Have you ever tried marijuana? (pot, grass, hash, etc. )?" If a subject responded affirmatively to any one question (or indicated an age when they first used marijuana), lifetime marijuana use was scored a " 1 ", while an indication of never using marijuana resulted in a score of "0". The reliability for the scale was above 0.7 for the first two measurement occasions, .64 on the third occasion, and .69 at the fourth occasion.”, page 15

The assessment of outcome is made blind Not applicable Blinding to exposure status was not applicable for this study

Where blinding was not possible, there is Not reported some recognition that knowledge of exposure status could have influenced the assessment of outcome

The measure of assessment of exposure is Well covered p. 15 reliable

Evidence from other sources is used to Well covered $=1.7$ demonstrate that the method of outcome assessment is valid and reliable

Exposure level or prognostic factor is as- Well covered 4 waves, page 17 sessed more than once

Confounding

Media campaigns for the prevention of illicit drug use in young people (Review) 
The main potential confounders are iden- Adequately addresses tified and taken into account in the design and analysis p. 16

Standard errors, e.g. Table 1 and 2, p. 18

Have confidence intervals been provided? Well covered

Standard errors, e.g. Table 1 and 2, p. 18

Overall assessment of the study

How well was the study done to minimise the risk of bias or confounding, and to establish a causal relationship between exposure and effect?

Code,+++ , or -

Taking into account clinical considerations, your evaluation of the methodology used, and the statistical power of the study, are you certain that the overall effect is due to the exposure being investigated?
Fairly: selectivity (do no know if representative); no propensity scoring for national media campaign
Are the results of this study directly appli- Unclear cable to the patient group targeted in this guideline?
Results are applicable to US youth; it is unclear whether they are generalisable outside the US

\section{Description of the study}

Do we know who the study was funded by? Public Funds (NIDA)

"This research was supported by grant DA12360 from the National Institute on Drug Abuse (NIDA) to the first author.", page 12

How many centres are patients recruited 20 communities

from?

From which countries are patients selected? (Select all those involved. Note additional countries after 'Other')

What is the social setting (i.e. type of envi- Mixed ronment in which they live) of patients in the study?

What criteria are used to decide who should IRB requirements be INCLUDED in the study? p. 14

\section{USA}

"The average rate of student participation in each school was $32 \%$ of total student enrolment, lower than the prior study because of stricter IRB requirements being imposed 
Table 2. 'Risk of bias' assessment of cohort studies (Hornik 2006, Scheier 2010, Slater 2011)

on recruitment procedures", page 15

What criteria are used to decide who should Exaggerators be EXCLUDED from the study?
"Students who responded that they had tried all drugs listed including one that had been invented were considered exaggerators and were excluded from analyses; there were no more than $0.4 \%$ of such exaggerators in any given wave of data collection.", page 15
What intervention or risk factor is investigated in the study? (Include dosage where appropriate) (a) school- and community-based media intervention 'Be Under Your Influence' and (b) national anti-drug media campaign 'Above the Influence' p. 12

Exposure versus drug use/aspirations/autonomy; exposure $\mathrm{x}$ time versus drug use/ aspirations/autonomy
What comparisons are made in the study (i.e. what alternative treatments are used to compare the intervention/exposure with). Include dosage where appropriate
Randomisation: not applicable for mass media campaign, but done for 'Be Under Your Own Influence' school- and community-based media intervention
What methods were used to randomise patients, blind patients or investigators, and to conceal the randomisation process from investigators?

How long did the active phase of the study last?
Autumn 2005 to Spring $2009 \quad(-42$ months)

How long were patients followed up for, 24 months during and after the study?

List the key characteristics of the patient population. Note if there are any significant differences between different arms of the trial

$48 \%$ males, $52 \%$ females and a mean age at baseline of 12.4 years $(\mathrm{SD}=0.6) ; 75 \%$ were European-American, $11.5 \%$ AfricanAmerican, and $13.5 \%$ of other racial backgrounds One-quarter of the youth were of Hispanic ethnicity
Record the basic data for each arm of the study. If there are more than 4 arms, note data for subsequent arms at the bottom of the page

\section{p. 15}

Table 1 and 2, page 18

Table 1 and 2 , page 18

Record the basic data for each IMPORTANT outcome in the study. If there are more than 4, note data for additional outcomes at the bottom of the page 
Notes. Summarise the authors' conclusions. Results indicate that earlier effects of the'Be Add any comments on your own assessment of Under Your Own Influence' intervention the study, and the extent to which it answers replicated only in part and that the most your question plausible explanation of the weaker effects is high exposure to the similar but more extensive ONDCP 'Above the Influence' national campaign. Self reported exposure to the ONDCP campaign predicted reduced marijuana use, and analyses partially support indirect effects of the 2 campaigns via aspirations and autonomy

SD: standard deviation

IRB = Institutional Review Board, is a committee that has been formally designated to approve, monitor, and review biomedical and behavioral research involving humans

Table 3. Measurement scales used in included studies

\begin{tabular}{|c|c|c|c|c|}
\hline Study & $\begin{array}{l}\text { Was a specific scale } \\
\text { developed? (Yes/no/un- } \\
\text { clear) }\end{array}$ & $\begin{array}{l}\text { Measurement scale(s) } \\
\text { used }\end{array}$ & Reference & $\begin{array}{l}\text { Was the scale adapted? } \\
\text { (Yes/no/unclear) }\end{array}$ \\
\hline \multirow[t]{3}{*}{ Palmgreen 1991} & No & $\begin{array}{l}\text { Sensation seeking Scale, } \\
\text { Form V }\end{array}$ & $\begin{array}{l}\text { Zuckerman, M (1979) } \\
\text { Sensation seeking: be- } \\
\text { yond the optimal level } \\
\text { of arousal. Hillsdale, NJ: } \\
\text { Lawrence Erlbaum Asso- } \\
\text { ciates, Inc }\end{array}$ & No \\
\hline & No & $\begin{array}{l}\text { In- } \\
\text { struments used in a con- } \\
\text { tinuing survey of young } \\
\text { people by the Institute } \\
\text { for Social Research at the } \\
\text { University of Michigan } \\
\text { (NB to measure levels of } \\
\text { use of illicit drugs) }\end{array}$ & $\begin{array}{l}\text { Johnston LD, Bachman } \\
\text { JG, O'Malley } \\
\text { PM (1982). Monitoring } \\
\text { the future: questionnaire } \\
\text { responses from the na- } \\
\text { tions' high school se- } \\
\text { niors, 1981. Ann Arbor: } \\
\text { University of Michigan, } \\
\text { Survey Response Centre, } \\
\text { Institute for Social Re- } \\
\text { search }\end{array}$ & Yes \\
\hline & Yes & $\begin{array}{l}\text { Behavioural Intention } \\
\text { Index } \\
\text { p. } 221 \text { "immediately af- } \\
\text { ter the second viewing of } \\
\text { the PSA, subjects were } \\
\text { asked "If you wanted in- } \\
\text { formation about alterna- }\end{array}$ & $\mathrm{n} / \mathrm{a}$ & $\mathrm{n} / \mathrm{a}$ \\
\hline
\end{tabular}


Table 3. Measurement scales used in included studies (Continued)

\begin{tabular}{|c|c|c|c|c|}
\hline & & $\begin{array}{l}\text { tives to drug use, how } \\
\text { likely it is, on a scale of } 1 \\
\text { to } 5 \text {, that you would call } \\
\text { na } 800 \text { hotline?" }\end{array}$ & & \\
\hline & Yes & $\begin{array}{l}\text { Attitude towards drug } \\
\text { use } \\
\text { p. } \\
\text { "After behavioural inten- } \\
\text { tion was measured, sub- } \\
\text { jects were asked to indi- } \\
\text { cate on a scale of } 1 \text { to } 5 \\
\text { how they felt about their } \\
\text { personal use of drugs in } \\
\text { relation to each of six ad- } \\
\text { jectives word pairs." }\end{array}$ & $\mathrm{n} / \mathrm{a}$ & $\mathrm{n} / \mathrm{a}$ \\
\hline Kelly 1992 & Unclear & Not mentioned & $\mathrm{n} / \mathrm{a}$ & $\mathrm{n} / \mathrm{a}$ \\
\hline Polansky 1999 & No & $\begin{array}{l}\text { Drug Attitude Scale } \\
(12 \text { items on a Likert } \\
\text { scale) }\end{array}$ & $\begin{array}{l}\text { Swisher JD, Horan JJ } \\
\text { (1973). The Pennsylva- } \\
\text { nia State University Eval- } \\
\text { uation Scales. In LA } \\
\text { Abrams, E Garfield \& } \\
\text { JD Swisher (eds). Ac- } \\
\text { countability in drug ed- } \\
\text { ucation: a model for } \\
\text { evaluation (pp 87-99). } \\
\text { Washington, DC: Drug } \\
\text { Abuse Council }\end{array}$ & $\begin{array}{l}\text { Unclear } \\
\text { (: in the text is men- } \\
\text { tioned "updated version" } \\
\text { but no further clarifica- } \\
\text { tion) }\end{array}$ \\
\hline & No & $\begin{array}{l}\text { Tentative Drug Use Scale } \\
\text { (10 items scale) }\end{array}$ & $\begin{array}{l}\text { Horan JJ, Williams JM } \\
\text { (1975). The tentative } \\
\text { drug use scale: a quick } \\
\text { and relatively problem } \\
\text { free outcome measure } \\
\text { for drug abuse preven- } \\
\text { tion projects. Journal of } \\
\text { Drug education; 5: 381- } \\
4\end{array}$ & No \\
\hline & Yes & $\begin{array}{l}\text { Help-Seeking Question- } \\
\text { naire and Knowledge } \\
\text { Questionnaire } \\
\text { p. } 190 \text { "two 10-items } \\
\text { achievement rests were } \\
\text { developed for this study" }\end{array}$ & $\mathrm{n} / \mathrm{a}$ & $\mathrm{n} / \mathrm{a}$ \\
\hline
\end{tabular}


Table 3. Measurement scales used in included studies (Continued)

\begin{tabular}{|c|c|c|c|c|}
\hline & No & $\begin{array}{l}\text { Drug Conformity Scale } \\
\text { (16 questions reflecting } \\
\text { varying levels of assertive } \\
\text { competency) }\end{array}$ & $\begin{array}{l}\text { Horan } \\
\text { JJ, Williams JM (1982) } \\
\text {. Longitudinal study of } \\
\text { assertion training as a } \\
\text { drug abuse prevention } \\
\text { strategy. American Edu- } \\
\text { cational Research Jour- } \\
\text { nal; 19: 341-51 }\end{array}$ & No \\
\hline \multirow[t]{3}{*}{$\begin{array}{l}\text { Palmgreen } 2001 \\
\text { (Stephenson 1999) }\end{array}$} & Yes & $\begin{array}{l}\text { Beliefs } \\
12 \text { marijuana-related be- } \\
\text { liefs about occasional } \\
\text { use of marijuana and } \\
12 \text { belief items about } \\
\text { regular marijuana use } \\
\text { were assessed on a } 4- \\
\text { point scale with the re- } \\
\text { sponse options of dis- } \\
\text { agree strongly, disagree } \\
\text { somewhat, agree some- } \\
\text { what and agree strongly }\end{array}$ & $\mathrm{n} / \mathrm{a}$ & $\mathrm{n} / \mathrm{a}$ \\
\hline & Yes & $\begin{array}{l}\text { Attitudes } \\
\text { Seven marijuana-related } \\
\text { attitudes } \\
\text { about occasional use and } \\
7 \text { items about regular use } \\
\text { were assessed on a } 4- \\
\text { point scale, with the re- } \\
\text { sponse options of dis- } \\
\text { agree strongly, disagree } \\
\text { somewhat, agree some- } \\
\text { what and agree strongly }\end{array}$ & $\mathrm{n} / \mathrm{a}$ & $\mathrm{n} / \mathrm{a}$ \\
\hline & Yes & $\begin{array}{l}\text { Intentions } \\
\text { Participants were asked } \\
\text { their intent to engage in } \\
\text { experimental or regular } \\
\text { marijuana use in the fu- } \\
\text { ture. With } 2 \text { items on } \\
\text { a 3-point scale with the } \\
\text { response options prob- } \\
\text { ably will not, probably } \\
\text { will and definitely will }\end{array}$ & $\mathrm{n} / \mathrm{a}$ & $\mathrm{n} / \mathrm{a}$ \\
\hline Miller 2000 & Yes & $\begin{array}{l}\text { Use } \\
\text { Recent drug use was } \\
\text { measured by asking re- } \\
\text { spondents about the fre- }\end{array}$ & $\mathrm{n} / \mathrm{a}$ & $\mathrm{n} / \mathrm{a}$ \\
\hline
\end{tabular}

Media campaigns for the prevention of illicit drug use in young people (Review) 
Table 3. Measurement scales used in included studies (Continued)

\begin{tabular}{|c|c|c|c|c|}
\hline & & $\begin{array}{l}\text { quency and recency with } \\
\text { which they used } 10 \text { types } \\
\text { of drugs (using com- } \\
\text { monly recognised } \\
\text { names): cannabis, co- } \\
\text { caine, other stimulants, } \\
\text { tranquillisers, sedative- } \\
\text { hypnotics, hallucino- } \\
\text { gens, opioids, phencycli- } \\
\text { dine, amyl and butyl ni- } \\
\text { trates and inhalants such } \\
\text { as glue, paint or gasoline } \\
\text { (4- point scale ranging } \\
\text { from } 1 \text { = never to } 4= \\
\text { at least once in the past } \\
\text { month) }\end{array}$ & & \\
\hline & Yes & $\begin{array}{l}\text { Risks perception } \\
\text { Risk } \\
\text { assessment included } 13 \\
\text { items regarding the ex- } \\
\text { tent to which students } \\
\text { perceived risk or conse- } \\
\text { quences related to alco- } \\
\text { hol or other drug use. } \\
\text { Personal risk for alco- } \\
\text { hol and other drug prob- } \\
\text { lems was judged relative } \\
\text { to students' perceptions } \\
\text { of "most people" (rang- } \\
\text { ing from } 1=\text { higher than } \\
\text { most people to } 3=\text { lower } \\
\text { than most people) }\end{array}$ & $\mathrm{n} / \mathrm{a}$ & $\mathrm{n} / \mathrm{a}$ \\
\hline Palmgreen 2001 & No & $\begin{array}{l}\text { Brief Sensation Seeking } \\
\text { Scale }\end{array}$ & $\begin{array}{l}\text { Hoyle RH, Stephenson } \\
\text { MT. The sensation seek- } \\
\text { ing scale for adolescents. } \\
\text { In: Lennox RD, Scott- } \\
\text { Lennox JA, Cutler BL, } \\
\text { eds. Applied Psychomet- } \\
\text { rics for Health Out- } \\
\text { comes Research. Chapel } \\
\text { Hill, NC: Health Statis- } \\
\text { tics Lab. }\end{array}$ & No \\
\hline Fishbein 2002 & Yes & $\begin{array}{l}\text { Specifically developed } \\
\text { instrument } \\
\text { p. } 241 \text { "the instrument } \\
\text { for the study consisted }\end{array}$ & $\mathrm{n} / \mathrm{a}$ & $\mathrm{n} / \mathrm{a}$ \\
\hline
\end{tabular}

Media campaigns for the prevention of illicit drug use in young people (Review) 
Table 3. Measurement scales used in included studies (Continued)

\begin{tabular}{|c|c|c|c|c|}
\hline & & $\begin{array}{l}\text { of questionnaire with } 3 \\
\text { parts." } \\
\text { First: demographic ques- } \\
\text { tions } \\
\text { Second: series of ques- } \\
\text { tions on realism/con- } \\
\text { tent/recall of interven- } \\
\text { tion } \\
\text { Third: assessment of the } \\
\text { respondent perceptions } \\
\text { of the danger and harm- } \\
\text { ful effects of engaging in } \\
8 \text { risky behaviours } \\
\text { - perceived danger = } 1 \\
\text { item per behaviour on } \\
\text { yes/no basis } \\
\text { - perceived harmfulness } \\
=1 \text { item per behaviour } \\
\text { on a 5-point scale } \\
\text { - perceived norms = } 1 \\
\text { item per behaviour on a } \\
5 \text {-point scale }\end{array}$ & & \\
\hline Yzer 2003 & Yes & $\begin{array}{l}\text { A specific questionnaire } \\
\text { was developed for the } \\
\text { study. Available upon re- } \\
\text { quest by the authors (p. } \\
\text { 135) } \\
\text { Intention to use mari- } \\
\text { juana: } 1 \text { to } 2 \text { (depending } \\
\text { on the first answer) items } \\
\text { using a } 4 \text {-point scale } \\
\text { Attitude: } 4 \text { items using a } \\
7 \text {-point scale } \\
\text { Outcome beliefs: } \\
36 \text { items using a 5-point } \\
\text { scale }\end{array}$ & $\mathrm{n} / \mathrm{a}$ & $\mathrm{n} / \mathrm{a}$ \\
\hline Slater 2006 & No & $\begin{array}{l}\text { Selected items from the } \\
\text { American Drug and Al- } \\
\text { cohol Survey } \\
\text { Alcohol lifetime score: } 3 \\
\text { items } \\
\text { Smoking lifetime score: } \\
3 \text { items } \\
\text { Marijuana lifetime score: } \\
5 \text { items }\end{array}$ & $\begin{array}{l}\text { American Drug and Al- } \\
\text { cohol Survey, with per- } \\
\text { mission by the Rocky } \\
\text { Mountain Behavioural } \\
\text { Science Institute }\end{array}$ & No \\
\hline
\end{tabular}

Media campaigns for the prevention of illicit drug use in young people (Review) 
Table 3. Measurement scales used in included studies (Continued)

\begin{tabular}{|c|c|c|c|c|}
\hline \multirow[t]{3}{*}{ Zhao 2006} & Yes & $\begin{array}{l}\text { Intentions not to use/to } \\
\text { reduce use/to stop use }\end{array}$ & $\mathrm{n} / \mathrm{a}$ & No \\
\hline & Unclear & $\begin{array}{l}\text { Attitudes towards illicit } \\
\text { drug use: } 7 \text {-point scale } \\
\text { from }-3(\mathrm{bad} / \text { foolish/...) } \\
\text { to }+3 \text { (good/wise/...) }\end{array}$ & $\mathrm{n} / \mathrm{a}$ & $\mathrm{n} / \mathrm{a}$ \\
\hline & Yes & $\begin{array}{l}\text { Percep- } \\
\text { tions (including percep- } \\
\text { tions of peer norms and } \\
\text { perceptions about illicit } \\
\text { drug use): } 5 \text {-point scales } \\
\text { from }-2 \text { to }+2 \text {. "Although } \\
\text { we did some analyses at } \\
\text { the level of individual be- } \\
\text { liefs, we generally used } \\
\text { two types of belief clus- } \\
\text { ters in our analyses" }\end{array}$ & $\mathrm{n} / \mathrm{a}$ & No \\
\hline \multirow[t]{3}{*}{ Czyzewska 2007} & Unclear & $\begin{array}{l}\text { Declared intention to } \\
\text { use marijuana }\end{array}$ & & $\mathrm{n} / \mathrm{a}$ \\
\hline & Unclear & $\begin{array}{l}\text { Atti- } \\
\text { tudes towards illicit drug } \\
\text { use (pre-test explicit at- } \\
\text { titudes): 10-point Likert } \\
\text { scales }\end{array}$ & & $\mathrm{n} / \mathrm{a}$ \\
\hline & Yes & $\begin{array}{l}\text { Attitudes towards illicit } \\
\text { drug use (post-test im- } \\
\text { plicit attitudes): IAT test. } \\
\text { "Two computerized Im- } \\
\text { plicit Association Tests } \\
\text { (IAT) were designed to } \\
\text { assess implicit attitudes } \\
\text { to tobacco and mar- } \\
\text { ijuana. [..] The only } \\
\text { difference to the stan- } \\
\text { dard IAT procedure was } \\
\text { the extended number of } \\
\text { practice trials to } 40 \text { in } \\
\text { order to reduce the typ- } \\
\text { ical effect of order in } \\
\text { which the combined cat- } \\
\text { egorization tasks are per- } \\
\text { formed" }\end{array}$ & $\begin{array}{l}\text { See Table } 1 \text { for IAT test } \\
\text { content } \\
\text { Scale was adapted from: } \\
\text { Greenwald AG, McGhee } \\
\text { DE, Schwartz JLK } \\
\text { (1998). Measuring indi- } \\
\text { vidual differences in so- } \\
\text { cial cognition: The Im- } \\
\text { plicit Association Test. } \\
\text { Journal of Personality } \\
\text { and Social Psychology; } \\
74: 1464-80 \\
\text { With updates from: } \\
\text { Greenwald AG, Nosek } \\
\text { BA, Banaij MR (2003) } \\
\text {. Understanding and us- } \\
\text { ing the Implicit Associ- } \\
\text { ation Test: An improved } \\
\text { scoring algorithm. Jour- }\end{array}$ & Yes \\
\hline
\end{tabular}

Media campaigns for the prevention of illicit drug use in young people (Review) 
Table 3. Measurement scales used in included studies (Continued)

\begin{tabular}{|c|c|c|c|c|}
\hline & & & $\begin{array}{l}\text { nal of Personality and } \\
\text { Social Psychology; } 85(2) \\
: 197-216\end{array}$ & \\
\hline & Unclear & $\begin{array}{l}\text { Attitudes towards illicit } \\
\text { drug use (post-test ex- } \\
\text { plicit attitudes): } 3 \text { sets of } \\
7 \text { 5-point scales (= } 215 \text { - } \\
\text { point scales) }\end{array}$ & & $\mathrm{n} / \mathrm{a}$ \\
\hline Hornik 2006 & No & $\begin{array}{l}\text { National Survey of Par- } \\
\text { ents and Youth (NSPY). } \\
3 \text { types of measures: re- } \\
\text { called exposure to anti- } \\
\text { drug messages aired by } \\
\text { the campaign and other } \\
\text { sources; cognitions and } \\
\text { behavior related to mar- } \\
\text { ijuana, as outcomes; and } \\
\text { individual and house- } \\
\text { hold characteristics, in- } \\
\text { cluding a wide range of } \\
\text { variables known to be re- } \\
\text { lated to drug cognitions } \\
\text { and use and to exposure } \\
\text { to anti-drug messages }\end{array}$ & $\begin{array}{l}\text { http://archives. } \\
\text { drugabuse.gov/ } \\
\text { initiatives/westat/ }\end{array}$ & No \\
\hline Scheier 2010 & Yes & $\begin{array}{l}\text { Alcohol and Drug Use } \\
\text { Assessment of alcohol } \\
\text { and drug use relied on an } \\
\text { Anonymous Computer } \\
\text { Assisted Self-report In- } \\
\text { terview (ACASI) }\end{array}$ & $\mathrm{n} / \mathrm{a}$ & $\mathrm{n} / \mathrm{a}$ \\
\hline \multirow[t]{2}{*}{ Fang 2010} & No & $\begin{array}{l}\text { Occasions of use in the } \\
\text { past } 30 \text { days } \pm \text { standard } \\
\text { error, SE }\end{array}$ & $\begin{array}{l}\text { None, but it is a standard } \\
\text { question in this field }\end{array}$ & No \\
\hline & Unclear & $\begin{array}{l}\text { Intentions not to use/to } \\
\text { reduce use/to stop use: } \\
\text { 5-point scales; higher } \\
\text { scores are better. No ad- } \\
\text { ditional information }\end{array}$ & & Unclear \\
\hline Lee 2010 & No & $\begin{array}{l}\text { 90-day mar- } \\
\text { ijuana use: "items were } \\
\text { adapted from the Global } \\
\text { Appraisal of Individual } \\
\text { Needs-I" }\end{array}$ & $\begin{array}{l}\text { Dennis ML, Titus JC, } \\
\text { Diamond G, Donald- } \\
\text { son J, Godley SH, Tims } \\
\text { FM. The CYT Steer- } \\
\text { ing Committee (2002) }\end{array}$ & Yes \\
\hline
\end{tabular}

Media campaigns for the prevention of illicit drug use in young people (Review)

Copyright $\odot 2013$ The Cochrane Collaboration. Published by John Wiley \& Sons, Ltd. 
Table 3. Measurement scales used in included studies (Continued)

\begin{tabular}{|c|c|c|c|}
\hline & & $\begin{array}{l}\text { The cannabis youth } \\
\text { treatment (CYT) experi- } \\
\text { ment: Rationale, } \\
\text { study design and analy- } \\
\text { sis plans. Addiction; } 97 \\
\text { (Suppl 1): 16-34 }\end{array}$ & \\
\hline No & $\begin{array}{l}\text { Intentions not to use/to } \\
\text { reduce use/to stop use: } \\
\text { 4-point score (higher = } \\
\text { more "con- } \\
\text { templation"). "Contem- } \\
\text { plation to change mar- } \\
\text { ijuana use was assessed } \\
\text { with four items (alpha } \\
=0.79 \text { ) adapted from } \\
\text { the Readiness to Change } \\
\text { Questionnaire (RTCQ)" }\end{array}$ & $\begin{array}{l}\text { Heather N, Gold R, } \\
\text { Roll- } \\
\text { nick S (1991). Readi- } \\
\text { ness to change ques- } \\
\text { tionnaire: User's manual. } \\
\text { (Tech. Rep. 15). Kens- } \\
\text { ington, Australia: Na- } \\
\text { tional Drug and Alcohol } \\
\text { Research Center, Uni- } \\
\text { versity of New South } \\
\text { Wales }\end{array}$ & Yes \\
\hline No & $\begin{array}{l}\text { Knowledge about the ef- } \\
\text { fects of illicit drugs on } \\
\text { health: negative conse- } \\
\text { quences due to mari- } \\
\text { juana use. } 5 \text {-point score } \\
\text { (from } 0=\text { never to } 4 \\
\text { = more than } 10 \text { times). } \\
\text { "Consequences of mari- } \\
\text { juana use were assessed } \\
\text { using the Rutgers Mer- } \\
\text { ijuana Problem Index } \\
\text { (RMPI)" }\end{array}$ & $\begin{array}{l}\text { White HR, Labouvie } \\
\text { EW, Papadaratsakis V } \\
\text { (2005). Changes in sub- } \\
\text { stance use during the } \\
\text { transition to adulthood: } \\
\text { A comparison of college } \\
\text { students and their non- } \\
\text { college age peers. Journal } \\
\text { of Drug Issues; } 35: 281- \\
306\end{array}$ & Unclear \\
\hline
\end{tabular}

No
Frequency of cannabis use: times per week $\pm \mathrm{SE}$ in the past 12 months "Cannabis use was assessed

from a questionnaire in the 2007 National Drug Strategy Household Survey (NDSHS) that identified the frequency of use of cannabis [1]."

Institute of Health and Welfare. 2007 National Drug Strategy Household Survey: First Results. Canberra: AIHW; 2008

Attitudes towards illicit National Health Promo- Unclear drug use: score \pm SE "At- tion Associates (NHPA) titudes towards cannabis Incorporated. Life Skills were measured by four Training Questionnaireitems from the Life Skills 


\begin{tabular}{|c|c|c|c|c|}
\hline & & $\begin{array}{l}\text { Training Questionnaire } \\
\text { [37], which has accept- } \\
\text { able internal consistency } \\
(\mathrm{a}=0.86) . ”\end{array}$ & $\begin{array}{l}\text { Middle School. New } \\
\text { York: NHPA; } 2004\end{array}$ & \\
\hline & No & $\begin{array}{l}\text { Knowledge about the ef- } \\
\text { fects of illicit drugs on } \\
\text { health: score } \pm \text { SE } \\
\text { "The cannabis knowl- } \\
\text { edge question- } \\
\text { naire was adapted from } \\
\text { the Cannabis Quiz and } \\
\text { included } 16 \text { items [33]." }\end{array}$ & $\begin{array}{l}\text { Bleeker A, Malcolm A. } \\
\text { The } \\
\text { Cannabis Quiz. Sydney: } \\
\text { Manly Drug Education } \\
\text { and Counselling Centre; } \\
2001\end{array}$ & Yes \\
\hline & No & $\begin{array}{l}\text { Knowledge about the ef- } \\
\text { fects of illicit drugs on } \\
\text { health: score } \pm \text { SE } \\
\text { "Cannabis harms were } \\
\text { assessed with six } \\
\text { questions derived from } \\
\text { the Adolescent Cannabis } \\
\text { Problems Questionnaire } \\
\text { (test-retest reliability, } r= \\
0.91 \text { [ }[35] . "\end{array}$ & $\begin{array}{l}\text { Martin G, Copeland J, } \\
\text { Gilmour S, Gates P, } \\
\text { Swift W. The adoles- } \\
\text { cent cannabis problems } \\
\text { questionnaire (CPQ-A) } \\
\text { : psychometric proper- } \\
\text { ties. Addictive Behaviors } \\
\text { 2006; 31: 2238-48 }\end{array}$ & No \\
\hline Schwinn 2010 & No & $\begin{array}{l}\text { Past } 30- \\
\text { day drug use (marijuana) } \\
: \text { occasions of use (0 to } \\
40) \\
\text { “...adapted } \\
\text { from the CDC's Youth } \\
\text { Risk Behavior Survey } \\
\text { (YRBS; Centers for Dis- } \\
\text { ease Control and Preven- } \\
\text { tion 2005), asked girls to } \\
\text { report how many times } \\
\text { in the past month and } \\
\text { week they used alcohol, } \\
\text { cigarettes, marijuana, co- } \\
\text { caine, } \\
\text { methamphetamines, } \\
\text { and ecstasy. Response } \\
\text { options ranged from ”0 } \\
\text { times" to "40 or more } \\
\text { times." Test-retest relia- } \\
\text { bility for YRBS items is } \\
0.82 \text { to } 0.95 \text { (Centers for } \\
\text { Disease Control and Pre- } \\
\text { vention 2004)" }\end{array}$ & $\begin{array}{l}\text { Centers for Disease } \\
\text { Control and Prevention. } \\
\text { (2005). Youth Risk Be- } \\
\text { havior Survey. Retrieved } \\
\text { February 20, 2009, from } \\
\text { http://www.cdc.gov/ } \\
\text { healthyyouth/yrbs/ }\end{array}$ & Yes \\
\hline
\end{tabular}


Table 3. Measurement scales used in included studies (Continued)

\begin{tabular}{|c|c|c|c|c|}
\hline & \\
\hline & No & $\begin{array}{l}\text { Past } 30 \text {-day drug use, } \\
\text { poly drug use (cigarettes, } \\
\text { marijuana cocaine, in- } \\
\text { halants, met., ectasy): } 7 \text { - } \\
\text { point score ( } 0 \text { to } 6) . \\
\text { Same as above }\end{array}$ & Same as above & Yes \\
\hline & No & $\begin{array}{l}\text { Past } 30 \text {-day drug use, } \\
\text { total substance }(=\text { poly } \\
\text { drug use }+ \text { alcohol): } 8 \text { - } \\
\text { point score ( } 0 \text { to } 7) \text {. } \\
\text { Same as above }\end{array}$ & Same as above & Yes \\
\hline \multirow[t]{3}{*}{$\begin{array}{l}\text { Idaho Meth 2010; } \\
\text { Colorado Meth 2011; } \\
\text { Georgia Meth 2011; } \\
\text { Hawaii Meth 2011; } \\
\text { Wyoming Meth 2011 }\end{array}$} & No & $\begin{array}{l}\text { Past- } \\
\text { year and past-month use } \\
\text { of methamphetamine: } \\
\text { "Have used meth in past } \\
\text { year"; "Have used meth } \\
\text { in past month" }\end{array}$ & $\mathrm{n} / \mathrm{a}$ & Unclear \\
\hline & Unclear & $\begin{array}{l}\text { Attitudes towards illicit } \\
\text { drug use: "Please indi- } \\
\text { cate how much you ap- } \\
\text { prove or disapprove of } \\
\text { the following activities. } \\
\text { " (Strongly disapprove, } \\
\text { strongly/somewhat ap- } \\
\text { prove) }\end{array}$ & $\mathrm{n} / \mathrm{a}$ & Unclear \\
\hline & Unclear & $\begin{array}{l}\text { Perceptions (in- } \\
\text { cluding perceptions of } \\
\text { peer norms and percep- } \\
\text { tions about illicit drug } \\
\text { use: binary and categor- } \\
\text { ical questions, such as } \\
\text { "How difficult, or easy, } \\
\text { do you think it would } \\
\text { be for you to get each } \\
\text { of the following types } \\
\text { of drugs?" (easy, diff- } \\
\text { cult) and "Please indi- } \\
\text { cate how much risk, if } \\
\text { any, you think there is in- } \\
\text { volved in each of the fol- } \\
\text { lowing activities." (Great } \\
\text { risk, great/moderate risk, } \\
\text { little/no risk) }\end{array}$ & $\mathrm{n} / \mathrm{a}$ & Unclear \\
\hline
\end{tabular}


Table 3. Measurement scales used in included studies (Continued)

\begin{tabular}{|c|c|c|c|c|}
\hline Slater 2011 & Yes & $\begin{array}{l}\text { Description of } \\
\text { study measures and sur- } \\
\text { vey components (p. 15) } \\
\text { Autonomy inconsistent } \\
\text { with marijuana use: } 4 \\
\text { items on a 4-point scale } \\
\text { Aspirations inconsistent } \\
\text { with marijuana use: } 3 \\
\text { items on a 4-point scale } \\
\text { Lifetime marijuana use: } \\
4 \text { items } \\
\text { Exposure to ONDCP's } \\
\text { campaign: } 1 \text { item on a 3- } \\
\text { point scale }\end{array}$ & $\mathrm{n} / \mathrm{a}$ & $\mathrm{n} / \mathrm{a}$ \\
\hline \multirow[t]{3}{*}{ Carpenter 2011} & No & Lifetime marijuana use & $\mathrm{n} / \mathrm{a}$ & Unclear \\
\hline & No & $\begin{array}{l}\text { Past-month marijuana } \\
\text { use }\end{array}$ & $\mathrm{n} / \mathrm{a}$ & Unclear \\
\hline & No & Alcohol use & $\mathrm{n} / \mathrm{a}$ & Unclear \\
\hline
\end{tabular}

IAT: Implicit Association Test

n/a: not applicable

ONDCP: Office of National Drug Control Policy

SE: standard error

A P PEN DICES

Appendix I. CENTRAL search strategy

ID Search

Hits

\#1 MeSH descriptor: [Substance-Related Disorders] explode all 10,355

trees

\#2 ((stimulant* or polydrug* or drug* or substance) near/3 14,750

(abuse* or abusing or consumption or addict* or disorder* or

intoxicat* or misus* $^{*}$ or use*)):ti,ab 
(Continued)

\#3 (abuse* or abusing or consumption or addict* or disorder* or 198,966 intoxicat ${ }^{*}$ or misus* or use* $^{*}$ :ti,ab

\#4 MeSH descriptor: [Narcotics] explode all trees 681

$\begin{array}{lll}\text { \#5 heroin:ti,ab } & 762\end{array}$

\#6 MeSH descriptor: [Street Drugs] explode all trees 196

\#7 MeSH descriptor: [Amphetamine] explode all trees 632

\#8 (amphetamine* or dextroamphetamine* or 1442 methamphetamine or Methylamphetamine*):ti,ab,kw (Word variations have been searched)

\#9 (ecstasy or MDMA or hallucinogen*):ti,ab,kw (Word varia- 234 tions have been searched)

\#10 MeSH descriptor: [Cocaine] explode all trees 576

\#11 (crack or cocaine):ti,ab,kw (Word variations have been 1953 searched)

\#12 MeSH descriptor: [Cannabis] explode all trees

\#13 (cannabis or marijuana or marihuana or Hashish):ti,ab,kw 1158 (Word variations have been searched)

\#14 (Lysergic next Acid):ti,ab,kw 76

\#15 LSD:ti,ab,kw (Word variations have been searched) 131

\#16 (benzodiazepine* or barbiturate* or ketamine or solvent or 6370 inhalant):ti,ab,kw (Word variations have been searched)

\#17 (benzodiazepine* or barbiturate* or ketamine or solvent or 6370 inhalant):ti,ab, kw (Word variations have been searched)

$\# 18 \# 4$ or \#5 or \#6 or \#7 or \#8 or \#9 or \#10 or \#11 or \#12 or \#13 11,919 or \#14 or \#15 or \#16 or \#17

\begin{tabular}{lll}
$\# 19$ & $\# 3$ and $\# 18$ & 6547 \\
\hline$\# 20 \quad \# 1$ or $\# 2$ or $\# 19$ & 26,077 \\
\hline
\end{tabular}

\#21 MeSH descriptor: [Mass Media] explode all trees

\#22 MeSH descriptor: [Internet] explode all trees 
(Continued)

\begin{tabular}{|c|c|c|}
\hline \#23 & MeSH descriptor: [Videotape Recording] explode all trees & 790 \\
\hline \#24 & “Tv”:ti,ab,kw (Word variations have been searched) & 386 \\
\hline \#25 & $\begin{array}{l}\text { (media or communication* or audiovisual or telecommunica- } \\
\text { tion* or radio or television or internet or campaign* or advert* } \\
\text { or twitter or facebook) (Word variations have been searched) }\end{array}$ & 27,766 \\
\hline \#26 & $\# 21$ or $\# 22$ or $\# 23$ or $\# 24$ or $\# 25$ & 28,828 \\
\hline \#27 & MeSH descriptor: [Adolescent] explode all trees & 68,885 \\
\hline \#28 & $\begin{array}{l}\text { adolescen* or preadolescen* or child* or teen* or youth* or } \\
\text { young or kid* or juvenile* or minors or boy* or girl*:ti,ab,kw } \\
\text { (Word variations have been searched) }\end{array}$ & 157,753 \\
\hline \#29 & $\# 27$ or \#28 & 157,753 \\
\hline \#30 & $\# 20$ and \#26 and \#29 & 566 \\
\hline
\end{tabular}

Appendix 2. PubMed (MEDLINE) search strategy

\begin{tabular}{|c|c|c|}
\hline Search & Query & Items found \\
\hline \#16 & Search $(((\# 3)$ AND \#4) AND \#11) AND \#15 & 5877 \\
\hline$\# 15$ & Search ((\#12) OR \#13) OR \#14 & $3,041,802$ \\
\hline$\# 14$ & $\begin{array}{l}\text { Search } \\
\text { lescen*[tiab] OR preadolescen*[tiab] OR child*[tiab] OR } \\
\text { teen*[tiab] OR youth*[tiab] OR young[tiab] OR kid*[tiab] } \\
\text { OR juvenile*[tiab] OR minors[tiab] OR boy*[tiab] OR } \\
\text { girl*[tiab] }\end{array}$ & $1,662,519$ \\
\hline \#13 & Search “Child”[Mesh] & $1,457,004$ \\
\hline$\# 12$ & Search “Adolescent”[Mesh] & $1,498,465$ \\
\hline$\# 11$ & Search $((((\# 5)$ OR \#7) OR \#8) OR \#9) OR \#10 & 797,788 \\
\hline$\# 10$ & $\begin{array}{l}\text { Search media[tiab] OR Communication*[tiab] OR audiovi- } \\
\text { sual[tw] OR telecommunication*[tw] OR Educat*[tiab] OR } \\
\text { radio[tw] OR television[tw] OR TV[tiab] OR internet[tw] } \\
\text { OR campaign*[tw] OR advert*[tw] OR twitter[tw] OR face- } \\
\text { book[tw] OR “instant messaging" [tw] }\end{array}$ & 751,996 \\
\hline
\end{tabular}




\begin{tabular}{|c|c|c|}
\hline$\# 9$ & Search "Telecommunications" [Mesh] & 54,815 \\
\hline$\# 8$ & Search Videotape Recording[Mesh] & 9970 \\
\hline$\# 7$ & Search "Internet" [Mesh] & 43,359 \\
\hline$\# 5$ & Search "Mass Media”[Mesh] & 37,325 \\
\hline$\# 4$ & $\begin{array}{l}\text { Search "heroin"[Mesh] OR heroin[tiab] OR "Street } \\
\text { Drugs"[Mesh] OR "Designer Drugs"[Mesh] OR "Crack Co- } \\
\text { caine"[Mesh] OR "Lysergic Acid Diethylamide"[Mesh] OR } \\
\text { drug*[tiab] OR polydrug[tiab] OR substance[tiab] OR hal- } \\
\text { lucinogen*[tw] OR cocaine[tw] OR amphetamine*[tw] OR } \\
\text { "lysergic acid diethylamide"[tw] OR LSD [tiab] OR ke- } \\
\text { tamine[tw] OR cannabis[tw] OR marihuana[tw] OR mar- } \\
\text { ijuana[tiab] OR hashish[tw] OR steroid*[tw] OR mor- } \\
\text { phine[tiab] OR ecstasy[tw] OR MDMA[tw] OR benzodi- } \\
\text { azepine[tw] }\end{array}$ & $1,136,251$ \\
\hline$\# 3$ & Search (\#1) OR \#2 & $1,812,638$ \\
\hline$\# 2$ & $\begin{array}{l}\text { Search abus*[tiab] OR consumption[tiab] OR misus*[tiab] } \\
\text { OR use*[tiab] OR addict*[tiab] OR disorder*[tiab] }\end{array}$ & $1,570,344$ \\
\hline$\# 1$ & Search "Substance-Related disorders" [Mesh] & 344,574 \\
\hline
\end{tabular}

\section{Appendix 3. EMBASE search strategy}

\section{ID Query}

\#1 'substance abuse'/exp

\#2 'drug abuse'/exp

\#3 abus*:ab,ti OR consumption:ab,ti OR misus*:ab,ti OR use*:ab,ti OR addict*ab,ti OR disorder*ab,ti

\#4 \#1 OR \#2 OR \#3

\#5 heroin:ab,ti OR drug*:ab,ti OR polydrug:ab,ti OR substance:ab,ti OR hallucinogen*:ab,ti OR cocaine:ab,ti OR amphetamine*:ab,ti OR 'lysergic acid diethylamide':ab,ti OR lsd:ab,ti OR ketamine:ab,ti OR cannabis:ab,ti OR marihuana:ab, ti OR marijuana:ab,ti OR hashish:ab,ti OR steroid*:ab,ti OR morphine:ab,ti OR ecstasy:ab,ti OR mdma:ab,ti OR benzodiazepine:ab,ti

\#6 'diamorphine'/exp 
(Continued)

\begin{tabular}{|c|c|}
\hline \#7 & 'designer drug'/exp \\
\hline$\# 8$ & 'street drug'/exp \\
\hline \#9 & 'cocaine'/exp \\
\hline$\# 10$ & 'cannabis smoking'/exp \\
\hline$\# 11$ & \#5 OR \#6 OR \#7 OR \#8 OR \#9 OR \#10 \\
\hline$\# 12$ & 'mass medium'/exp \\
\hline \#13 & 'internet'/exp \\
\hline \#14 & 'videorecording'/exp \\
\hline$\# 15$ & 'telecommunication'/exp \\
\hline \#16 & $\begin{array}{l}\text { media:ab,ti OR communication*:ab,ti OR audiovisual:ab,ti OR telecommunication*:ab,ti OR educat*ab,ti OR radio:ab,ti } \\
\text { OR television:ab,ti OR tv:ab,ti OR internet:ab,ti OR campaign*:ab,ti OR advert*:ab,ti OR twitter:ab,ti OR facebook:ab,ti }\end{array}$ \\
\hline \#17 & \#12 OR \#13 OR \#14 OR \#15 OR \#16 \\
\hline \#18 & 'adolescent'/exp \\
\hline \#19 & 'child'/exp \\
\hline$\# 20$ & $\begin{array}{l}\text { adolescen*:ab,ti OR preadolescen*:ab,ti OR child*:ab,ti OR teen*:ab,ti OR youth*:ab,ti OR young:ab,ti OR kid*:ab,ti OR } \\
\text { juvenile*:ab,ti OR minors:ab,ti OR boy*:ab,ti OR girl*:ab,ti }\end{array}$ \\
\hline \#21 & \#18 OR \#19 OR \#20 \\
\hline \#22 & \#4 AND \#11 AND \#17 AND \#21 AND [embase]/lim \\
\hline
\end{tabular}

\section{Appendix 4. EPOC criteria for quality assessment of interrupted time series}

The following seven standard criteria should be used to assess the methodological quality of ITS designs included in EPOC reviews. Each criterion is scored DONE, NOT CLEAR or NOT DONE. The results of the quality assessment for each study are reported in the Characteristics of included studies table in RevMan. Examples can be obtained from the EPOC Group Co-ordinator. 


\begin{tabular}{|c|c|c|c|}
\hline \multirow[t]{2}{*}{ Criterion } & \multicolumn{3}{|l|}{ Score } \\
\hline & DONE & NOT CLEAR & NOT DONE \\
\hline \multicolumn{4}{|l|}{ a) Protection against secular changes } \\
\hline $\begin{array}{l}\text { The intervention is indepen- } \\
\text { dent of other changes }\end{array}$ & $\begin{array}{l}\text { If the intervention occurred } \\
\text { independent of other changes } \\
\text { over time }\end{array}$ & $\begin{array}{l}\text { If not specified (will be treated } \\
\text { as NOT DONE if information } \\
\text { cannot be obtained from the au- } \\
\text { thors) }\end{array}$ & $\begin{array}{l}\text { If reported that intervention } \\
\text { was not independent of other } \\
\text { changes in time }\end{array}$ \\
\hline
\end{tabular}

There are sufficient data points to enable reliable statistical inference (a) If at least 20 points are recorded before the intervention AND the authors have done a traditional time series analysis (ARIMA model)

OR (b) If at least 3 points are recorded pre and post intervention AND the authors have done a repeated measures analysis

OR (c) If at least 3 points are recorded pre and post intervention AND the authors have used ANOVA or multiple ttests AND there are at least 30 observations per data point
If not specified in paper, e.g. number of discrete data points not mentioned in text or tables (will be treated as NOT DONE if information cannot be obtained from the authors)
If any of the above conditions are unmet
If formal test for change in trend using appropriate method is reported (e.g. see Cook \& Campbell 1979)
If not specified in the paper (will If formal test for change in trend be treated as NOT DONE if has not been done information cannot be obtained from the authors)

\section{b) Protection against detection bias}

Intervention unlikely to affect If the investigators report that data collection

the intervention itself was unlikely to affect data collection (for example, sources and methods of data collection were the same before and after the intervention)
If not reported (will be treated as NOT DONE if information cannot be obtained from the authors)

If not specified (will be treated as NOT DONE if information cannot be obtained from the authors)
If the intervention itself was likely to affect data collection (for example, any change in source or method of data collection reported) that the primary outcome ables were assessed blindly OR the outcome variables are objective, e.g. length of hospital stay,
Blinded assessment of primary outcome $(s)^{*}$
If the authors state explicitly

Media campaigns for the prevention of illicit drug use in young people (Review)

Copyright $\odot 2013$ The Cochrane Collaboration. Published by John Wiley \& Sons, Ltd. 


\begin{tabular}{|c|c|c|c|}
\hline & $\begin{array}{l}\text { drug levels as assessed by a stan- } \\
\text { dardised test }\end{array}$ & & \\
\hline c) Completeness of data set & $\begin{array}{l}\text { If data set covers } 80 \% \text { to } 100 \% \\
\text { of the total number of partici- } \\
\text { pants or episodes of care in the } \\
\text { study }\end{array}$ & $\begin{array}{l}\text { If not specified (will be treated } \\
\text { as NOT DONE if information } \\
\text { cannot be obtained from the au- } \\
\text { thors) }\end{array}$ & $\begin{array}{l}\text { If data set covers less than } 80 \% \\
\text { of the total number of partici- } \\
\text { pants or episodes of care in the } \\
\text { study }\end{array}$ \\
\hline $\begin{array}{l}\text { d) Reliable primary outcome } \\
\text { measure }(s)^{* *}\end{array}$ & $\begin{array}{l}\text { If } 2 \text { or more raters with at } \\
\text { least } 90 \% \text { agreement or kappa } \\
\text { greater than or equal to } 0.8 \\
\text { OR the outcome is obtained } \\
\text { from some automated system, } \\
\text { e.g. length of hospital stay, drug } \\
\text { levels as assessed by a standard- } \\
\text { ised test }\end{array}$ & $\begin{array}{l}\text { If reliability is not reported for } \\
\text { outcome measures that are ob- } \\
\text { tained by chart extraction or } \\
\text { collected by an individual (will } \\
\text { be treated as NOT DONE if in- } \\
\text { formation cannot be obtained } \\
\text { from the authors) }\end{array}$ & $\begin{array}{l}\text { If agreement is less than } 90 \% \text { or } \\
\text { kappa is less than } 0.8\end{array}$ \\
\hline
\end{tabular}

*Primary outcome(s) are those variables that correspond to the primary hypothesis or question as defined by the authors. In the event that some of the primary outcome variables were assessed in a blind fashion and others were not, score each separately.

** In the event that some outcome variables were assessed in a reliable fashion and others were not, score each separately.

\section{Appendix 5. Quality Criteria for Cohort Controlled Studies (SIGN)}

\section{SIGN Methodology Checklist 3: Cohort studies}

Study identification (include author, title, year of publication, journal title, pages)

\begin{tabular}{l|l|l}
\hline Guideline topic: & Key Question No: Reviewer:
\end{tabular}

Before completing this checklist, consider:

1.Is the paper really a cohort study? If in doubt, check the study design algorithm available from SIGN and make sure you have the correct checklist

2.Is the paper relevant to key question? Analyse using PICO (Patient or Population Intervention Comparison Outcome). IF NO REJECT (give reason below). IF YES complete the checklist

Reason for rejection: 1 . Paper not relevant to key question $\lrcorner \quad 2$. Other reason $\llcorner\quad$ (please specify):

Please note that a retrospective study (i.e. a database or chart study) cannot be rated higher than +

Section 1: Internal validity

\section{In a well-conducted cohort study:}

1.1 The study addresses an appropriate and clearly focused question.[i]
Does this study do it?

Yes $\sqcup$

No $\lrcorner$

Can't say ㅁ 
(Continued)

Selection of subjects

1.2 The 2 groups being studied are selected from source popula- Yes

No

tions that are comparable in all respects other than the factor Can't say ㅁ

Does not apply under investigation.[ii]

1.3 The study indicates how many of the people asked to take Yes

No

part did so, in each of the groups being studied.[iii]

Does not apply

1.4 The likelihood that some eligible subjects might have the Yes

$\mathrm{No}=$

outcome at the time of enrolment is assessed and taken into Can't say $п$

Does not apply account in the analysis. [iv]

1.5 What percentage of individuals or clusters recruited into each arm of the study dropped out before the study was completed.

[v]

1.6 Comparison is made between full participants and those lost Yes

No

to follow-up, by exposure status.[vi]

Can't say

Does not apply ᄃ

\section{ASSESSMENT}

1.7 The outcomes are clearly defined.[i]

Yes

Nor

Can't say =

1.8

The assessment of out- Yes

No ᄃ

come is made blind to ex-

Can't say -

Does not apply posure status. If the study is retrospective this may not be applicable.[ii]

1.9 Where blinding was not possible, there is some recognition that knowledge of exposure status could have influenced the assessment of outcome. [iii]

\begin{tabular}{|c|c|c|c|}
\hline 1.10 & $\begin{array}{l}\text { The method of assessment } \\
\text { of exposure is reliable.[iv] }\end{array}$ & $\begin{array}{l}\text { Yes } \square \\
\text { Can't say = }\end{array}$ & No \\
\hline 1.11 & $\begin{array}{l}\text { Ev- } \\
\text { idence from other sources } \\
\text { is used to demonstrate that }\end{array}$ & $\begin{array}{l}\text { Yes } \\
\text { Can't say - }\end{array}$ & $\begin{array}{l}\text { No } \sqsubset \\
\text { Does not apply॰ }\end{array}$ \\
\hline
\end{tabular}

No ᄃ

Can't say - $\quad$ ᄂ 
the method of outcome assessment is valid and reliable. [v]

\section{CONFOUNDING}

The main potential con- Yes $\square$

No founders are identified and Can't say taken into account in the design and analysis. [vii]

\section{STATISTICAL ANALYSIS}

1.14 Have confidence intervals Yes

been provided?[viii]

\section{Section 2: OVERALL ASSESSMENT OF THE STUDY}

\begin{tabular}{|c|c|c|c|}
\hline 2.1 & $\begin{array}{l}\text { How well was the study } \\
\text { done to minimise the risk } \\
\text { of bias or confounding? [ix] }\end{array}$ & \multicolumn{2}{|c|}{$\begin{array}{l}\text { High quality }(++) \\
\text { Acceptable }(+) \\
\text { Unacceptable - reject } 0\end{array}$} \\
\hline 2.2 & $\begin{array}{l}\text { Taking into account clin- } \\
\text { ical considerations, your } \\
\text { evaluation of the method- } \\
\text { ology used, and the statis- } \\
\text { tical power of the study, } \\
\text { how strong do you think } \\
\text { the association between ex- } \\
\text { posure and outcome is? }\end{array}$ & & \\
\hline 2.3 & $\begin{array}{l}\text { Are the results of this study } \\
\text { directly applicable to the } \\
\text { patient group targeted in } \\
\text { this guideline? }\end{array}$ & Yes $\sqcup$ & $\mathrm{No} \sqcup$ \\
\hline
\end{tabular}

Notes. Summarise the authors' conclusions. Add any comments on your own assessment of the study, and the extent to which it answers your question and mention any areas of uncertainty raised above

[i] This relates to the risk of detection bias.* Once enrolled in the study, participants should be followed until specified end points or outcomes are reached. In a study of the effect of exercise on the death rates from heart disease in middle aged men, for example, participants might be followed up until death, or until reaching a predefined age. If outcomes and the criteria used for measuring them are not clearly defined, the study should be rejected.

Media campaigns for the prevention of illicit drug use in young people (Review) 
[ii] This relates to the risk of detection bias.* If the assessor is blinded to which participants received the exposure, and which did not, the prospects of unbiased results are significantly increased. Studies in which this is done should be rated more highly than those where it is not done, or not done adequately.

[iii] This relates to the risk of detection bias.* Blinding is not possible in many cohort studies. In order to asses the extent of any bias that may be present, it may be helpful to compare process measures used on the participant groups - e.g. frequency of observations, who carried out the observations, the degree of detail and completeness of observations. If these process measures are comparable between the groups, the results may be regarded with more confidence.

[iv] This relates to the risk of detection bias.* A well-conducted study should indicate how the degree of exposure or presence of prognostic factors or markers was assessed. Whatever measures are used must be sufficient to establish clearly that participants have or have not received the exposure under investigation and the extent of such exposure, or that they do or do not possess a particular prognostic marker or factor. Clearly described, reliable measures should increase the confidence in the quality of the study

[v] This relates to the risk of detection bias. ${ }^{*}$ The primary outcome measures used should be clearly stated in the study. If the outcome measures are not stated, or the study bases its main conclusions on secondary outcomes, the study should be rejected. Where outcome measures require any degree of subjectivity, some evidence should be provided that the measures used are reliable and have been validated prior to their use in the study.

[vi] This relates to the risk of detection bias.* Confidence in data quality should be increased if exposure level is measured more than once in the course of the study. Independent assessment by more than one investigator is preferable.

[vii] Confounding is the distortion of a link between exposure and outcome by another factor that is associated with both exposure and outcome. The possible presence of confounding factors is one of the principal reasons why observational studies are not more highly rated as a source of evidence. The report of the study should indicate which potential confounders have been considered, and how they have been assessed or allowed for in the analysis. Clinical judgement should be applied to consider whether all likely confounders have been considered. If the measures used to address confounding are considered inadequate, the study should be downgraded or rejected, depending on how serious the risk of confounding is considered to be. A study that does not address the possibility of confounding should be rejected.

[viii] Confidence limits are the preferred method for indicating the precision of statistical results, and can be used to differentiate between an inconclusive study and a study that shows no effect. Studies that report a single value with no assessment of precision should be treated with extreme caution.

[ix] Rate the overall methodological quality of the study, using the following as a guide: High quality (++): Majority of criteria met. Little or no risk of bias. Results unlikely to be changed by further research. Acceptable (+): Most criteria met. Some flaws in the study with an associated risk of bias. Conclusions may change in the light of further studies. Low quality (0): Either most criteria not met, or significant flaws relating to key aspects of study design. Conclusions likely to change in the light of further studies.

\section{CONTRIBUTIONS OFAUTHORS}

Marica Ferri and Fabrizio Faggiano conceived the systematic review and overviewed study inclusion and exclusion, methodological assessment of studies, and wrote the review. Marica Ferri and Elias Allara selected the studies for inclusion. Alessandra Bo and Elias Allara extracted the data from the studies and contributed to writing the review; Elias Allara contacted the trial authors for further information. Along with Alessandra Bo, Elias Allara input data for meta-analysis into Review Manager. Antonio Gasparrini and Elias Allara did the meta-analysis of interrupted time series studies.

Marica Ferri, Fabrizio Faggiano, Elias Allara and Alessandra Bo regularly discussed each step of review process and equally participated in each decision regarding the studies and the analysis.

Marica Ferri, Gregor Burkhart and Fabrizio Faggiano conceived the protocol, Elias Allara and Alessandra Bo performed the preliminary search strategy and participated in writing the protocol. Anna V Gyarmathy provided input to the protocol for the theories description and editing of the text.

Media campaigns for the prevention of illicit drug use in young people (Review) 


\section{DECLARATIONSOF INTEREST}

None of the authors report conflict of interest.

\section{SOURCES OF SUPPORT}

\section{Internal sources}

- European Monitoring Centre for Drugs and Drug Addiction, Portugal.

The authors were allowed to use their working time, the offices and the working resources (computers, printers, internet access) to conduct the systematic review.

\section{External sources}

- No sources of support supplied 